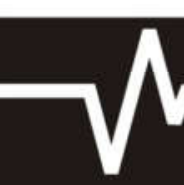




\section{Story For Everyone}

Muhlis Muhammad Abdullah

Nur Fitria Ayu Fahdila 


\title{
STORY FOR EVERYONE
}

Muhlis Muhammad Abdullah

Nur Fitria Ayu Fahdila

Tata Letak dan Desain Cover :

Muhlis Muhammad Abdullah

\section{Ukuran :}

Halaman Judul: 7, Halaman Naskah: 215, Uk: 14x20 cm

\section{ISBN :}

\author{
Support By : \\ RRI Sorong \\ Kedai Ingat Kopi \\ Kedai Tapak Kopi \\ Forum Literasi Sorong \\ Jurusan Dakwah dan Komunikasi STAIN Sorong \\ Dayu Rifanto \\ Forum Belajar Menulis \\ Kedua Orang Tua \\ Allah SWT \\ Sekedar catatan kecil buat kalian :
}

Isi buku bebas diapakan, asal jangan dibuat ulang

\footnotetext{
Copyright $\mathbb{0} 2019$

All Right Reserved

IDP

(Ibo Dream Production)

Jl.Cempedak Jalur D, Kelurahan Malagusa Kecamatan Aimas

Kota Sorong Provinsi Papua Barat

98418

Contact Person: 082199753860

E-mail: muhlisabdull96@gmail.com
} 


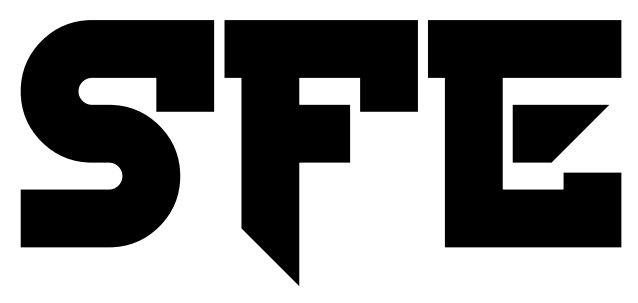

\section{story for everyone}

please tell me something about

$$
\text { your story' }
$$

because, i don't know everything

about your story'

ada cerita diujung senja yang

terapung sendiri

sayangnya matahari perlahan

sirna dan lekas berganti

$$
\begin{gathered}
\text { just, } \\
\text { ya, you know, i'm speechless to } \\
\text { say something }
\end{gathered}
$$




\section{Prakata}

\section{Assalamualaikum,}

Hai guys, ini aku, kenal aku gak? Yah semoga dirimu tak melupakanku begitu saja. Aku menulis ini bukan karena aku ingin menjadi penulis seperti mereka para penulis terkenal di luar sana.

Tulisan ini berasal dari salinan yang aku simpan di dalam kepala ini, awalnya hanya sebuah coretan-coretan tapi coba aku untuk menuliskan agar bisa dibaca oleh semua orang yang bergelut didunia sastra. Kenapa aku membuat ini? Aku hanya ingin meninggalkan jejak kalau aku pernah hidup di sini walaupun ada tujuan tertentu tapi biar DIA saja yang tahu apa tujuanku membuat ini.

Aku tak pandai merangkai kata demi kata, karena keterbatasanku merasakan kepekaan terhadap lingkungan yang selalu melindungiku.

Jika ditanya lagi, kenapa aku tak peka?, aku bingung di mana waktu untuk peka, yah begitulah, aku hanya akan terdiam di sudut kamar dan berbincang mesra dengan tembok kamarku.

Awalnya memang kedua orang tuaku tak mendukung hal ini, setelah aku berhasil meyakinkan mereka bahwa ini hanyalah 
salinan singkat berbentuk sajak, mereka pun memberikan kepercayaan itu padaku.

Tak layak memang laki-laki sepertiku ini selalu memuja dirimu, karena dirimu adalah ciptaan terindah dari-Nya. Aku hanya ingin sampaikan, isi buku ini sedang ku jalani semua, jadi doakan aku ya.

Belajar dari semua kisah di masa lalu, aku selalu terjatuh pada kesalahan yang sama. Tapi aku yakin ini semua bisa ku hadapi, karena katamu "kamu mampu membahagiakan semuanya tentunya dengan caramu sendiri, be yourself okay".

Tak hanya itu, di dalam buku ini bukan hanya tulisanku saja, aku mengajak sahabat jauhku untuk menambah beberapa halaman agar buku ini tidak terlalu membosankan.

Akhir kata, semoga setiap sajaknya bisa dijadikan pembelajaran untuk siapa saja, dan semoga setiap cerita bisa dijadikan sandaran untuk menambah semangat menjalani kehidupan. Story for everyone bukan tentang justifikasi tetapi tentang bagaimana cara menyikapi.

Aku persembahkan buku ini untuk kedua orang tuaku, adikadikku, dan semua aspek utama dalam kehidupanku

Terima kasih Ya rabb Engkau buat indah semua ceritaku, Engkau datangkan guru sebaik Baginda Rasulullah SAW, semoga aku, kamu, dan mereka semua bisa mendapat syafaat dari beliau. Wassalamu'alaikum 


\section{Isi Buku}

Buku ini berisi kumpulan sajak yang

sengaja aku tuliskan agar semua perasaan dapat tersampaikan

Mungkin agak sedikit berat karena ini

menyangkut bagaimana caraku

mengekspresikan

Selain itu, di dalam buku ini terdapat

sedikit bumbu untuk menambah

semangat dalam menjalani hidup

\section{Selamat Menikmati}

Dan

Selamat datang kedalam ceritaku 
"A Poam"

1 | SFE 
inilah catatan usangku, maaf akupun sedang berusaha melakukan

itu

jika ditanya mengapa?

karena aku hanya mampu melakukan seperti ini maof jika bahasa tubuhku terlalu rancu untuk dipublikasikan karena ini hanyalah sebuah salinan dari perasaanku

"muhlis muhammad abdullah" 
Sesuatu yang abstrak akan sulit untuk dijelaskan

\author{
Seperti diri Kita, \\ Diri kita selalu melihat abstrak \\ tapi, selalu saja tak pernah bisa \\ mengerti apa maksud dan tujuannya
}

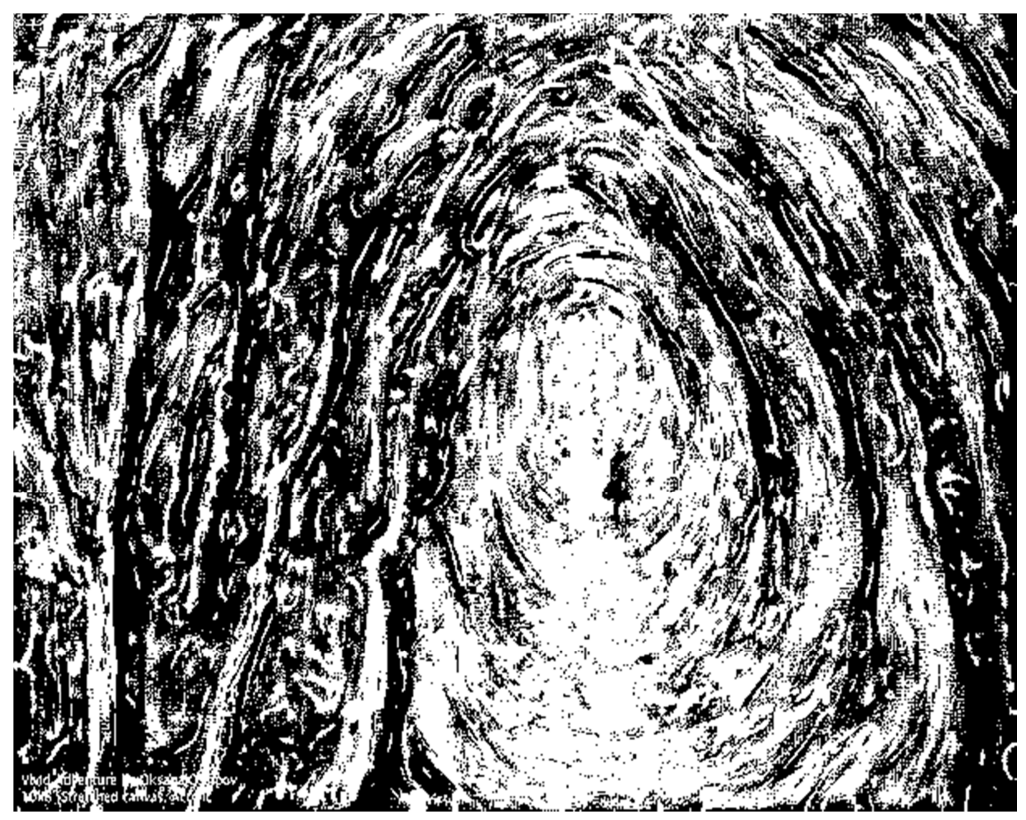




\section{Abstrak}

Abstrak akan selalu samar, begitu juga rasa ini

Kenapa menjadi samar? Karena ini masalah hati Sebenarnya simple, ketika aku mengaitkan dengan-Nya

Semua terlihat lebih jelas tanpa ada batasan luasnya

Terkadang kita memaksa indra untuk merasa

Tanpa mencoba bagaimana mempelajari rasa Terkadang sesuatu yang abstrak sering terlupakan Tanpa jeda kita selalu berusaha melangkah kedepan

Niat yang ku usahakan, agar bisa bersamanya

Semoga lekas tercapaikan tentu itu berkat-Nya Satu yang ku pinta agar DIA selalu memudahkanmu

Aku titip dia ya rabb, tolong jaga dirinya selalu

Abstrak adalah singkatan penjelasan

Yang disajikan untuk memudahkan segala pembahasan

Abstrak itu kayak sebuah perasaan

Mudah disampaikan tetapi sulit dilepaskan

Jika dirimu bertemu abstrak disebuah kisah

Pelajari semua agar dirimu selalu terarah

Bukan mengabaikan seolah itu sampah

Bisa jadi itu adalah sebuah hidayah

Aku, kamu, dan mereka pasti memiliki kisah abstrak Karena setiap manusia akan selalu kuat walau sudah retak Bersyukurlah karena Allah sebaik pemberi Abstrak 


\section{Ada Cinta}

Sebab cinta tidak pernah palsu

Tapi kepalsuan itu yang memaksa cinta

Sebab cinta itu tidak pernah pilu Mungkin karena mereka yang terlalu memaksa

Ada cinta yang terkadang menjadi tak baik Adalah cinta yang memaksa diri untuk memilikinya

Kenapa bisa cinta itu menjadi tak baik?

Karena cinta itu tak memiliki semua tentangnya

Mencoba itu pada usia yang dini

Hanya karena mereka tak ingin sendiri

Mereka ingin melakukan apa yang orang lain lakukan Ingin merasakan sesuatu yang belum pernah dirasakan

Hubungan itu akan menjadi rumit

Dan akan membuatmu terlilit

Demi status yang tak seberapa

Kamu rela mengorbankan apa saja

Fokusku teralihkan dengan pertanyaannya

Yang sedikit membuatku bertanya-tanya

Entahlah aku memilih untuk mengalihkannya

Dengan alasan tak masuk di dalam logika

Pergilah sejauh mungkin dari hadapanku Jika kamu hanya melukai dan menyayat hati

Tinggalkan aku sendiri dalam tatapanmu Jika kamu hanya datang sebentar lalu pergi 
Sebab cinta menghadirkan rindu Dan rindu itu, akan terus mengganggu Sebab rindu akan selalu hadir padaku Yang sedang jatuh cinta kepadamu

Setiap cerita pasti memiliki kenangan Entah kenangan itu darinya atau dariku Sebab kenangan selalu menyenangkan Dan asik ketika kita mulai menceritakan

Ada cinta, dibalik rumitnya kisah kita Entah kapan ini berakhir Aku pun tak tahu, aku rasa kita harus berbicara Untuk membuat ini berakhir

Karena bagiku, cinta yang sebenarnya adalah cinta yang akan kurasa setiap hari Kebahagiaan tanpa jeda,

Ketika aku tersenyum dan kamu membalas senyumanku dengan ketulusan hati

Ada cinta disaat pernikahan kita Yang ku rangkai hingga kamu sulit untuk melupakan Jangan lupa berterima kasih kepada-Nya Karena-Nya kita bisa merasakan semua kebahagiaan 


\section{Adikku Sayang}

Hai adikku

Its me, your brother

Kalian adalah pelengkap dalam kehidupanku Posisi kalian selalu ada dibawah ibu dan ayahku Walau tak banyak waktu ku sempatkan untukmu Aku akan selalu berbuat yang terbaik untukmu

Ingatlah selalu kata-kataku Aku bukan bermaksud menceramahimu Ambillah ilmu dariku jika itu perlu Ingatlah, buang segala yang tak perlu

Kalian akan selalu aku sayangi Walau terkadang aku selalu iri Bantu aku untuk mulai membenahi Hubungan yang sempat aku ingkari

Mungkin karena selalu berbeda persepsi Aku selalu saja bertentangan dengan kalian Tapi itu aku yang dahulu, sekarang aku perbaiki Berusaha memperbaiki sebaik mungkin demi kalian

Janganlah kalian bermain hati

Jika kalian takut tersakiti

Hiraukanlah untuk saat ini

Yang terpenting cukup kalian jalani

Perintah dari-Nya jangan kalian ingkari Karena DIA-lah yang menghadirkan kita didunia ini 
Bersyukurlah karena DIA membuat kita sehati

Untuk menuju kebahagiaan yang Hakiki

\author{
Buat kalian adikku \\ Kejarlah cita-citamu setinggi langit \\ Jangan takut untuk melangkahkan kakimu \\ Karena aku selalu ada untuk memberi semangat
}

Menurutku aku tak pantas dijadikan panutan

Jadikanlah ibu dan ayah sebagai patokan

Jangan sampai kalian salah mengidolakan

Karena aku selalu payah dalam kehidupan

\title{
Percayalah satu hal
}

DIA akan mempersatukan kita kelak

Berkumpul demi kebahagiaan yang tiada akhir

Yakinlah DIA tak pernah mengingkari

Berdo'alah selagi mulutmu mampu tuk meminta

Angkatlah kedua tanganmu dan memohonlah

Semoga DIA selalu melindungi dan mengampuni kalian Dan semoga DIA selalu memberikan rahmat kepada kalian Aamiin Ya Robbal 'Alamin 


\section{Akad}

Betapa bahagianya diriku Saat aku berdua denganmu Bercanda dengan dirimu Bersama habiskan waktu

Jika memang ini yang terakhir Aku tahu itu bukan masalah buatku

Mungkin itulah bagian dari takdir Jika kamu bukan miliknya pasti milikku

Janji akad yang terucap dari lidahku Aku harap kamu tak ragu dengan perkataanku Itulah janji yang aku ucapkan kepadamu Tapi jangan kamu bebankan semua kepadaku

Kita melangkah bersama Agar bisa berjalan seirama Melangkah menuju jalan-Nya Berjalan menuju ridho-Nya

Mentari hadir dan senyumanmu mengikuti Itulah keseharian yang aku lalui bersamamu Menikmati semua bersamamu hingga senja pergi Ini adalah pilihan terbaik dari-Nya untuk dirimu

DIA selalu punya rencana dibalik semua Kita takkan tahu, karena kita hanya bisa berencana Berdo'alah dan jangan ragu dengan segala keputusan milik-Nya 


\section{Aku Bahagia}

Aku berdiri di pelataran depan rumahku Dan melihat dua sejoli sedang jalan berdua Entah perasaan apa yang ada di dalam benakku Ingin sekali rasanya bisa seperti mereka

Aku tahu cinta selalu benar datangnya Hanya saja aku salah menetapkan waktunya Aku tahu dia datang jika sudah saatnya Hanya saja aku tak sabar dalam menantinya

Aku bahagia melihat sejoli itu Mungkin iri adalah rasa untuk menopang alasan Aku sadari tak harusnya begitu Karena tak semua dijalani melalui sebuah hubungan

DIA menciptakan kita berpasang-pasangan Lantas, apa hak kita meragukan yang sudah ditetapkan

DIA selalu memberikan apa yang kita inginkan Kita saja yang selalu memaksa atas semua keinginan

DIA menciptakan rasa yang tidak ada ujungnya Lantas, apa hak kita memaksa rasa yang tak seharusnya DIA selalu memberikan semua perasaan yang kita minta Kita saja yang meragukan atas semua pemberian-Nya

Aku bahagia dan sangat bahagia bersama-Nya Aku tahu tak semua yang kamu inginkan DIA berikan Karena seluruh Hidupku dan Hidupmu atas Kehendak-Nya Jadi Yakinkan semua Hatimu kepada-Nya 


\title{
Aku Harus Tahu Diri
}

Aku tahu dirimu ada karena-Nya Aku tahu dirimu ada karena cinta-Nya Aku tahu DIA yang menghadirkannya Aku juga tahu DIA yang memutuskannya

\author{
Aku harus tahu diri \\ Bahwa apa saja yang aku punya \\ Tak bisa aku miliki sendiri \\ Karena semua adalah milik-Nya \\ Aku harus tahu diri \\ Bahwa apa yang aku cinta \\ Adalah bagian dari rezeki \\ Yang hadir sesuai ketentuan-Nya
}

Aku harus tahu diri

Bahwa apa yang DIA perintah

Harus aku penuhi

Karena aku diciptakan untuk beribadah

\begin{abstract}
Dan aku harus tahu diri
Bahwa apa yang aku cinta Tak selamanya bisa aku miliki Walau dengan cara memaksa
\end{abstract}

Tahu diri karena DIA yang pantas

Pantas karena DIA tak mudah untuk dilepas

Dilepas hanya karena keinginan dunia yang melewati batas 


\section{Aku Menjauh}

Kamu tak tahu, Rasanya hatiku

Saat berhadapan kamu Serasa lama waktuku

Sakit memang mencintai dari jauh

Dan selalu saja aku dibuat jenuh

Aku tak tau bagaimana caranya

Sepertinya aku harus mengakhirinya

Aku menjauh dari dirimu

Karena diriku tak ingin melukaimu

Aku juga salah mencintaimu

Karena belum waktu kamu ada untukku

Biarkanlah semua mengalir semestinya

Biarkanlah hujan menghapus semua

Aku harus merelakan cinta ini

Demi kebaikan dirimu dan diri ini

Selamat jalan kekasih bayanganku

Yang selalu mengganggu dalam mimpiku

Terima kasih sudah hadir dalam kehidupanku

Selalu membuat diri ini tersenyum dengan candamu

Aku tahu, salah mencintaimu saat ini

Mungkin, nanti aku akan mencobanya lagi

Dalam ikrar cinta yang seharusnya

Agar aku mendapatkan ridho dari-Nya

Jangan pernah bosan memanggilku

Karena aku takkan bosan denganmu 
Bukan aku berharap lebih padamu Aku hanya tak ingin membuatmu membenciku

Hujan ini sedikit menghapus rasaku Derasnya sampai orang menghiraukanku

Berbicara tentang rasaku padamu Anggap saja itu kenangan dimasa lalu 


\section{Aku Muslim dan Aku Bukan Teroris}

Perkenalkan aku salah satu muslim Yang ingin membenarkan statement mereka

Jauh-jauh hari aku mencari tahu apa itu Islam Dan akhirnya, aku menemukannya

Islam tak pernah mengajarkanku

Tentang Radikalisme Islam tak pernah mengajarkanku Untuk menyakiti orang lain Dan Islam bukan sekedar agama Melainkan sebuah keyakinan Dan sebuah tujuan hidup

Jujur saja aku benci ketika mereka menilai Agamaku Jujur saja tak terima ketika mereka menginjak Agamaku But, my prophet don't teach me, to hurt each other

Mereka berkata bahwa Islam itu agama teroris Mereka berkata bahwa Islam itu agama yang keras Kenyataannya, aku tidak diajarkan untuk itu

Syahadat bukan sekedar Persaksianku Sholat bukan sekedar Tiang Agamaku

Puasa bukan sekedar Benteng Hawa Nafsuku

Zakat bukan sekedar Pembersih Hartaku Dan haji bukan sekedar Penyempurna Rukun Imanku 
Sebanyak apapun mereka berkata tentang Agamaku Akan aku patahkan dengan statementku

Mungkin saja mereka belum mengetahui

Betapa indahnya Agamaku

Dan Mungkin mereka belum mengetahui

Betapa damai Agamaku

Semoga mereka yang berlomba menjatuhkan Agamaku,

Lekas mendapat hidayah dari-Nya

\author{
I'm a Moslem \\ Islam is My Deen \\ And I'm proud be a Moslem
}




\section{Aku Yang Tidak Paham}

Aku menikmati hembusan angin yang sedikit panas Aku yang tidak paham, hanya menatap dan sulit melepas Kata-kataku yang dituliskan hanya berujung serangan balik Mungkin statementku hanya selalu menimbulkan delik

Tali sepatuku sering sekali menghambatku melangkah Karena aku sendiri tidak pernah mengikatnya dengan baik Kehaluan membuat rasa menghadirkan asa diujung arah Tak harus berbuat itu hanya karena ingin dipandang baik

Aku memburu langkah agar kelak tidak ketinggalan Terkadang aku lupa bagaimana cara melupakan Aku memburu perubahan agar lebih baik kedepan Terkadang aku lupa bagaimana cara mengikhlaskan

Satu tujuan langkah yang berujung kematian Bukan berarti semua tidak bisa dimanfaatkan Satu tatapan masa depan setelah kehidupan Bukan berarti semua tidak memiliki kesempatan

Aku yang tidak paham

Bukan berarti dengan begitu kamu menjatuhkan Aku yang tidak paham

Bukan berarti dengan begitu aku mudah direndahkan

Real of you, you need yourself, because you is you Tetaplah menjadi dirimu sendiri karena ketidak pahaman dirimu tidak akan membuatmu rendah di mata-Nya 


\section{Anugerah Terindah}

Aku jatuh hati padamu

Padamu anugerah terindahku

DIA membuat semua menjadi indah

Disaat aku memang benar-benar patah

DIA memberi anugerah terindah kepadaku

Karena aku juga cinta kepada-Nya

DIA memberi cinta yang setia padaku

Karena aku juga setia pada-Nya

Jujur saja aku tak pernah bosan

Bosan untuk selalu mencintai-Nya

Terkadang ada saja yang merasa bosan

Mungkin, karena sedikit mencintai-Nya

DIA memberikan tanpa aku meminta

Walau terkadang dalam do'a, aku sedikit memaksa

Memaksa bukan karena berharap diberikan

Tapi tujuan do'a juga bagian dari kebahagiaan

Dirimu begitu sempurna DIA ciptakan Maaf jika pujiku ini hanya untuk-Nya Aku takut jika terus memuji dirimu Dan membuat-Nya cemburu padaku

Kamu adalah Anugerah Terindah

Mungkin aku harus membuka hati dan mataku Agar kelak anugerah terindah itu terus bersamaku Berawal dan berakhir bahagia untuk menggapai ridho-Nya 


\section{Art Of Ego}

Huh, aku lelah mengendalikan egoku sendiri

Entah kenapa semua jadi berantakan seperti ini

Ego yang tak aku kelola menghancurkan semua

Menjadikan kondisi semakin menyesakkan jiwa

Tak ada manusia yang tak berEgo

Karena dunialah aku, kamu dan mereka memiliki ego

Aku merasakan hilang fokus seketika

Hilang arah karena semakin jauh dari-Nya

Ego adalah sesuatu yang tidak mudah diredam

Karena Art Of Ego akan selalu beragam

Terkadang kita susah me-manage ego kita

Mungkin membara karena nafsu belaka

Kenyamanan yang aku cari seharusnya

Menjadi bosan dan hilang entah kemana

Kita tidak sadar bahwa Ego banyak kerugiannya

Semakin tinggi Ego, semakin tinggi pula mudhorotnya

DIA memberikan hati untuk meredam Ego

DIA memberikan akal untuk berfikir sebelum bertindak

Kalau kita selalu mengutamakan Ego

Bagaimana kita bisa menjadi manusia yang baik

Allah sebaik dzat yang maha sempurna

Dan Art of Ego adalah bagian dari pemberian-Nya Hadapi dengan sabar selesaikan dengan akal terbuka 


\title{
Ayah
}

Hai ayah, lama aku tak bercanda bersamamu Engkau adalah panutan dalam keluargaku Yang aku jadikan tiang dalam kehidupanku Semoga kelak aku bisa terus bersamamu

\author{
Diam-diam aku mengagumimu \\ Tapi maaf aku tak bisa memberitahu \\ Aku tahu engkau takkan percaya padaku \\ Walau aku juga tak yakin bisa seperti dirimu
}

Diri ini selalu saja jatuh kedalam lubang yang sama Dan engkau tahu, bahwa itu bukan sebuah problema Diri ini selalu saja menghiraukan perkataanmu Dengan ikhlas engkau selalu menerimaku

Jika diri ini terus memikirkan materi Aku akan payah ketika menjadi sepertimu Jika diri ini terus bergantung pada kondisi Aku akan selalu gagal membina keluargaku

Selama ini aku selalu acuh padamu Padahal diam-diam engkau memperhatikanku

Kasih ibu memang tak ter-elakkan Tapi bantuan darimu takkan terbalaskan

Ibuku mengajariku akan kasih sayang Dan engkau mengajarkanku untuk selalu tenang

Dalam kondisi apapun aku harus ikhlas Berbuat semua tanpa menuntut balas 
Dirimu adalah imam yang aku idamkan

Berapa lama lagi aku haru belajar agar bisa seperti dirimu

Dirimu adalah pemimpin yang aku idamkan

Berapa lama lagi aku terus menunda untuk patuh padamu

Pelajaran yang tak ku dapatkan disekolah

Selalu ku dapatkan ketika aku berbagi cerita denganmu

Aku akan terus belajar dan terus menelaah

Agar bisa menjadi imam dan pemimpin sepertimu

\author{
Hai ayah, \\ Lewat tulisan ini aku sampaikan \\ Aku hanyalah anakmu yang butuh dirimu
}

Hai lbu,

Jangan engkau iri dengan yang aku katakan Karena engkau adalah nama pertama di dalam do'aku

Semoga kelak kita dipersatukan Disyurga-Nya yang kita idam-idamkan

Ya Rabb lindungilah mereka berdua Ampunilah segala dosa mereka berdua

Lapangkanlah segala urusannya

Dan berikan tempat terbaik-Mu Aamiin

Dear abi, this is from your son 


\section{Bagaimana Jika?}

Aku manusia biasa yang tak sempurna

Bagaimana jika, aku kelak bersamamu Apakah dirimu bisa menerima aku apa adanya Menerima semua kekurangan dan kelebihanku

Dengan kekurangan kita saling memperbaiki

Dengan kelebihan kita saling melengkapi Bagaimana jika, aku dan dirimu berbeda persepsi? Apakah kamu akan pergi atau mencoba menyatukan persepsi?

Aku yang berbeda pemikiran denganmu

Dan dirimu punya kelebihan untuk mengubah itu

Bagaimana jika, aku masih mengabaikanmu? Apakah kamu akan hilang atau mencoba memahamkan diriku?

Aku yang keras kepala kepadamu

Dan dirimu punya kelembutan untuk meluluhkanku Bagaimana jika, aku tetap bersikeras atas pilihanku? Apakah kamu akan menyerah atau mencoba meyakinkan diriku?

Aku dan dirimu sudah pasti berbeda Karena Rahim yang mengeluarkan kita tak sama Aku harap kita bisa menyatukan tujuan Agar apa yang kita harapkan sukses dimasa depan 


\section{Bahagiamu, Bahagiaku juga}

Bahagiamu adalah bahagiaku juga Jangan pesimis dan teruskan melangkah

Tak apa jika kita tak bisa bersama Yakinlah, pilihan-Nya tak pernah salah

Aku Bahagia ketika melihatmu

Tenang saja takkan aku jadikan beban dalam kehidupanku

Aku akan dewasa dengan semua itu Karena mampu melewati beratnya ujian kesabaranku

Penantian yang belum berarti Dan selalu saja penuh misteri Membuatku semakin optimis Bukan malah jatuh dan pesimis

Mungkin itu yang menjadi pilihan terbaik Jadi terimalah dan tabahkan diri kepada-Nya Yakinlah dimata-Nya kamu akan selalu menarik Karena DIA telah mempersiapkan semuanya

Ingin sekali aku menikmati kopi bersamamu Tapi sayangnya masih butuh waktu yang cukup lama Aku dan dirimu juga harus mempersiapkan diri

Demi penantian yang sangat lama Dan hanya DIA yang tahu semua Entah dirimu bersamaku atau bersamanya Aku akan tetap bahagia ketika kamu bahagia 


\title{
Baiknya Ku Simpan
}

Masih seperti hari biasa

Aku saja menikmati suasana

Panas yang selalu membakar kulit

Membuat keadaan menjadi sedikit sulit

\begin{abstract}
Hitam putihnya kisahku
Selalu membuatku berfikir

Ingin sesekali aku berbagi denganmu

Tapi aku ketakutan keadaan semakin getir

Aku bingung bagaimana cara memulainya Sedang dirimu selalu saja dibuat terkesima Oleh mereka yang selalu melempar janji

Tapi entah, apakah mereka bisa menepati?
\end{abstract}

Memang tak pantas jika diri ini memaksa untuk mencinta Sedang dirimu selalu saja menolak untuk berbagi cerita Memang sedihmu selalu kamu tutupi dibalik tawamu Tapi, apakah aku tak pantas mendengar semua ceritamu?

Aku memang selalu lemah dengan perasaan Dan selalu saja jatuh ketika membawa perasaan Entahlah, itu hanyalah fana bagiku Yang hanya bisa melihat keindahanmu

Paras indahmu selalu membuatku ingin bercerita Walau sebenarnya kamu tak tahu yang aku rasakan Tapi tak penting jika kamu memaksa untuk bertanya Apa yang sebenarnya sedang aku rasakan 
Baiknya aku simpan dalam-dalam

Dan semoga tidak menjadi kenangan yang kelam

Memendam rasa memang tak asik

Tapi aku tak mau memaksa dan membuat pelik

Cukup aku nikmati keindahanmu dari jauh Karena aku tahu hatimu sangatlah rapuh Rapuh dengan godaan untuk selalu bersama Rapuh dengan godaan untuk dicinta seutuhnya

Kelak kamu bahagia dengan yang lebih baik dariku Dan aku harap DIA memberi yang terbaik untukmu Bukan hanya sesaat

Dan berakhir ketika tamat 


\section{Belajarlah dari Perkataanmu}

Sudah banyak contoh yang DIA hadirkan dihadapanmu

Tapi, kamu masih saja bertahan dengan kekuatan akalmu Kamu takkan pernah mengerti, jika tak pernah merasakan Maka dirimu harus pandai mengambil semua pelajaran

Aku bingung denganmu yang selalu merendahkan Apakah kamu tak pernah berfikir sebelum berkata? Apa dengan merendahkan, derajatmu semakin ditinggikan? Atau, berbicara seenaknya membuatmu lebih berkuasa?

Baru saja aku katakan janganlah kamu melukainya Tapi kamu masih saja dengan mudah melakukan itu Maaf saja, menurutku memang mudah untuk di katakan Tapi fikirkanlah, apakah dia mudah memaafkanmu?

Sudahlah, aku sudah pusing melihat dirimu Yang tak pernah mau belajar dari semua kondisi Aku pernah berkata, perkataan itu tak apa buatku

Tapi apakah dia mau memaafkan perkataan ini

Bukan bermaksud membela pihak yang terluka Hanya saja dirimu sudah terlanjur menyakiti Apa susahnya berbuat baik dengan dirinya? Ketika kamu menghargai, dia pasti lebih menghargai

Sudah aku bangun dengan baik Dengan mudahnya kamu meruntuhkan Semua terserah dirimu yang membuat pelik Aku sudah tak ingin lagi menyalahkan 
Apa sebenarnya yang kamu inginkan?

Jika kebahagian yang kamu inginkan

Bagaimana bisa?, kalau dirimu selalu mempermainkan

Mungkin, dirimu sendiri yang akan menyadarkan

Sudah lelah aku menampar dirimu

Dengan perkataan yang menurutku itu bisa

Ternyata kamu masih tetap sama seperti dulu

Terserahlah, itu pilihanmu dan aku tak akan memaksa

"Jadilah orang yang pandai merasa

Bukan merasa pandai

Karena dengan pandai merasa kamu akan saling mengerti" (Ustadz Abdul Somad Lc. MA) 


\section{Bersabar Di dalam Do'a}

Ada satu hal yang tak bisa dihindarkan

Yakni ketentuan dari-Nya

Walau kamu memaksa demi kebahagiaan

Itu semua tergantung pada-Nya

Bersabar di dalam do'a

Berusaha dengan kegigihan

Bersabar di dalam usaha

Demi sebuah kebahagiaan

Kamus kataku tak banyak

Maaf jika sajak ini sedikit membosankan

Biarkan aku berfikir sejenak

Untuk kembali menambah kata yang dituliskan

Kisah cintaku sungguh menakjubkan Hakikat bahagia memang benar aku rasakan

Sebelumnya memang tak aku dapatkan

Karena aku sangat lemah dengan perasaan

Bersabar di dalam do'a

Itu yang dikatakan oleh-Nya

DIA berkata teruslah berusaha

Dan dampingi selalu dengan Do'a

Jika apa yang aku nanti, tak ku dapatkan

Mungkin jalan lain yang DIA berikan

Aku takkan kecewa karena, DIA sebaik-baiknya tempat pengharapan 


\section{Bersamamu}

Kamu adalah penggalan di dalam do'aku

Bersamamu adalah salah satu keinginanku

Bukan karena kamu indah, aku terus memujimu

Tapi karena DIA begitu sempurna menciptakanmu

Sunset didermaga itu telah bergulir Memaksa lari dan membuat kakiku terkilir

Bukan karena aku takut akan kehilanganmu

Tapi karena aku takut semakin jauh dari-Nya

Perasaan yang menggebu-gebu

Membuat diri semakin dirundung pilu

Menggebu-gebu karena tak bisa dikondisikan Dan pilu karena perasaan yang selalu dikecewakan

Sebab cinta adalah suci

Aku ingin ini bisa menjadi janji

Janji antara kamu dan aku

Dan tentunya janji dengan Penciptaku

Hubungan baik, harus di bangun dengan cara baik

Dan aku tahu rencana-Nya adalah yang terbaik

Bersamamu dalam menikmati sisa umurku Menghabiskan waktu dalam setiap kehidupanku

Jika kelak aku tak bisa bersamamu

Aku percaya Pilihan-Nya adalah pilihan yang terbaik untuk diriku dan dirimu 


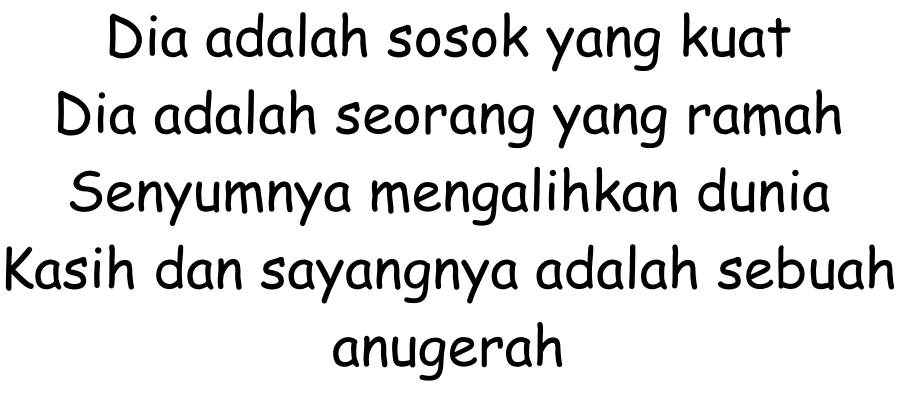

Jangan Kau lukai Dia, sebab Dia adalah titipan dari-Nya untuk kau jaga menggunakan cara-Nya

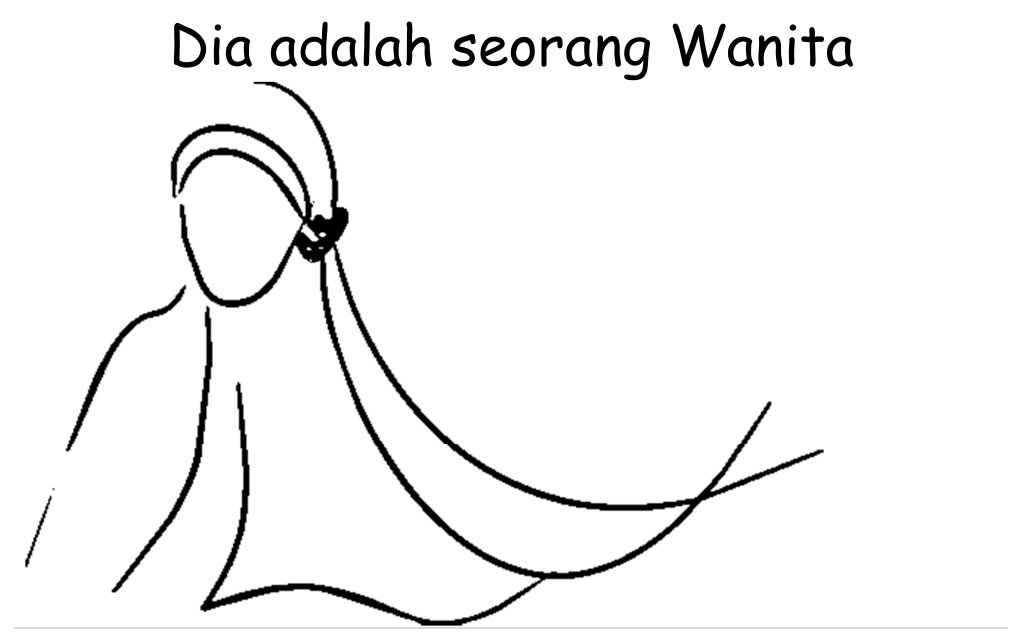




\title{
Bersyukurlah
}

Segala cara telah ku coba

Agar aku bisa sekedar berjalan tanpa dirinya

Namun semua, telah berbeda

Sulit sekali menghapus kenangan bersamanya

DIA mengingatkan ku untuk selalu bersyukur

Agar diri ini tidak terjatuh dan tersungkur

Memang kebanyakan dari mereka berkata

Move on itu bukan hal yang mudah sepertinya

Allah Mention in the Qur'an

"La Tahzan Innallaha Ma Ana"

Janganlah kamu berlarut dalam kesedihan

Sekalipun kita tersungkur, DIA akan selalu ada

\author{
Aku, kamu, dan mereka \\ Kita semua sama dimata-Nya \\ Jangan bangga dengan segalanya \\ Karena sifatnya hanya sementara
}

Bersyukurlah DIA memberikan aku dan kamu nikmat Bersyukurlah DIA memberikan aku dan kamu waktu Janganlah buat semua itu cepat berlalu seperti kilat Hanya menikmati sesaat lalu lupa di mana posisimu

\footnotetext{
Aku, kamu dan mereka

Kita semua adalah Hamba

Bersyukurlah, jika ingin kamu benar-benar inginkan

kebahagian akhirat dan dunia
} 


\section{Biarkan Saja}

Aku memulai tulisan dengan secerca harapan

Dan semoga harapanku bisa terwujurkan

Mereka selalu menilai aku seperti bawahan

Tak jadi masalah, karena mereka bebas menentukan

Lucu juga melihat kelakuan mereka

Yang selalu saja dibutakan oleh cinta

Cinta yang menurutku itu terpaksa

Karena mereka membutuhkan tawa

Tawa tak harus dengan bermain cinta Tapi dengan tawa kita bisa dapatkan cinta

Metodeku selalu saja dianggap sepele Karena mereka lebih senang bertele-tele

Dari caranya berbicara Sudah bisa ku buat kesimpulan

Bahwa kamu seperti mereka

Yang sangat membutuhkan kehangatan

Aku tau hanya manis saja

Semoga tidak lekas hilang

Manis yang terlalu memaksa

Demi kenangan yang akan datang

Cinta akan selalu penuh kepalsuan

Sebelum adanya ikatan dalam pernikahan

Diajak nikah nolak karena belum bisa menerima

Diajak pacaran tanpa koma langsung saja diterima -I don't understand- 


\title{
Bully
}

Stop dan akhiri, jangan lagi diteruskan

Karena itu semua bukanlah sebuah pujian

Stop dan berbaiklah, jangan lagi dilanjutkan

Karena ini semua bukan sebuah permainan

\author{
Bully?, \\ Kamu pasti tahu apa maksudnya \\ Sebenarnya tak masalah buatku, \\ Tapi bagaimana dengan orang lain?
}

Apa mereka menerima perkataanmu?

Apa mereka tahu, bahwa candaan adalah maksudmu?

Berkata baiklah, jika tak bisa maka diamlah Aku hanya menegur, jangan sampai kamu menyakitinya

Coba kita fikirkan sejenak, betapa bahayanya perkataan Setiap kita marah selalu saja kita menyakiti mereka Bahkan kita juga menyakiti mereka yang tak berakal

Belajarlah menjadi orang yang berpikiran dewasa Diamlah jika menurutmu ucapan itu bisa merusak suasana

Persekusi yang menjadi masalah terbesar buat kita semua Jagalah lisanmu, jika kamu ingin menjaga perasaannya

Ketika kamu berkata tanpa menggunakan logika Tanpa menggunakan spasi, tanpa menggunakan hati, dan tanpa melihat diri sendiri

Itu hanya akan melukai satu dan lainnya 
Perkataanmu adalah cerminan dirimu

Tak perlu aku berbicara lebih banyak lagi

Karena kamu pun mengetahui semua itu

Tak perlu aku jelaskan semuanya kembali

Bukan ingin membandingkan diriku dan dirimu

Sebab diriku belum tentu sebaik dirimu

Tetapi jika aku melihat begitu cara sosialmu

Tutur dan caramu, tak patut untuk ditiru

Ketika kita berusaha mengingatkan bahwa itu SALAH

Seolah-olah nasehat itu selalu dianggap SAMPAH

Mungkin saja, dia belum mengenal-Nya

Atau dia belum mendapat hidayah dari-Nya

Aku di sini hanya sekedar untuk mengingatkan

Dan tidak lebih,

Jika kamu membenciku karena perkataanku

Sampaikanlah kepadaku

Karena akan menjadi penyakit jika kamu hanya

memendamnya

Aku harap kamu memafkan aku

"Hai orang-orang yang beriman, janganlah sekumpulan orang laki-laki merendahkan kumpulan yang lain, boleh jadi yang ditertawakan itu

lebih baik dari mereka. Dan jangan pula sekumpulan perempuan merendahkan kumpulan lainnya, boleh jadi yang direndahkan itu lebih baik. Dan janganlah suka mencela dirimu sendiri dan jangan memanggil dengan gelaran yang mengandung ejekan. Seburuk-buruk panggilan adalah (panggilan) yang buruk sesudah iman dan barangsiapa yang tidak bertobat, maka mereka itulah orang-orang yang zalim" 


\title{
Cara Mencintaimu
}

\author{
"Aku mencintaimu" \\ Jika kamu kelak bertanya \\ "Karena apa kamu mencintaku?" \\ Aku mencintaimu tanpa karena
}

Diam, adalah caraku mencintaimu

Jika aku sampaikan kepadamu

Kamu takkan puas mendengar semua alasanku

Bahkan kamu akan selalu mempertanyakan soal itu

Aku akan berbicara banyak setelah akad terjadi

Bukannya memberi harapan palsu kepadamu Aku hanya tak ingin dengan perkataan, aku menyakiti Karena aku tahu, lembut sekali perlakuanmu padaku

Kecewa adalah hal biasa dalam percintaan Jika tak ingin kecewa janganlah membina hubungan

Itu terjadi dalam hubungan yang halal

Tapi tak menutup kemungkinan yang belum halal

Berbicara tentang cara mencintaimu Sudah aku katakan "Diam" adalah caraku

Mungkin lewat do'a aku sampaikan rinduku Lewat tulisan-tulisan, aku ungkapkan perasaanku

Mencintaimu adalah indah

Sebab cinta akan selalu indah

Dan cinta dari-Nya adalah yang paling indah

Dan berharap kepada-Nya takkan membuat patah 


\section{Cerita ku Untukmu}

Terbayang sebuah hal menyenangkan Yang membuat aku terlupa dengan keadaan

Sajak yang ku buat tak cukup meyakinkan Karena selalu putus di tengah dan akhir tulisan

Ada cerita dariku untukmu

Yang menurutku cukup menarik

Cerita tentang kehidupan masa depanku

Yang pasti, bukan sebuah kisah klasik

Cerita yang ku buat selalu saja sunyi

Karena selalu tak sesuai dengan hati

Masih ada saja yang mengganjal semua ini

Menjadikan cerita agak hambar seperti ini

Cerita ku untukmu

Kira-kira seperti apa itu

Yang pastinya itu akan menyenangkan

Asal kamu pahami dengan perasaan

Jangan dibawa hati, karena ini hanyalah cerita

Jika terbawa hati, cukup nikmati saja semua

Karena semua ini adalah pemberian dari-Nya Bersyukurlah karena DIA selalu memberikan kasih-Nya

Cerita ku untukmu akan selalu menyenangkan Jika dirimu mencoba menikmati dalam mendengarkan

Kamu akan mengerti apa isi cerita dariku untukmu Jika kamu tak mengerti, akan aku ceritakan lagi kepadamu 


\section{Cinta itu Sederhana}

Banyak orang yang berkata cinta itu menyakitkan Memang benar, menyakitkan jika selalu dipermainkan Aku bingung dengan mereka yang berkata begitu Apa mereka tak paham dengan makna cinta itu?

Cinta itu sederhana

Karena memberi tanpa meminta

Mengapa bisa sederhana?

Karena cinta bukan sekedar rasa

Kata mereka cinta itu buta Memang benar, siapa yang bilang cinta punya mata? Jika cinta memiliki mata Alasan terbesar mereka untuk mencinta adalah dunia

Ketika logika memaksakan rasa Nafsu akan selalu menjadi hal yang utama Justru rasa yang terpaksa akan merusak segalanya Dan akan membuat nada cinta menjadi tidak seirama

Aku percaya Cintaku tak akan abadi Sebab jasad ku takkan ku bawa setelah mati Cintaku abadi hanya untuk-Nya Karena DIA adalah alasan aku mencintaimu juga

Cinta itu sederhana Ketika kita mengerti maknanya Mengapa bisa sederhana?

Ketika kita dapatkan maka terimalah, jika tidak kita dapatkan harus bisa kita mengikhlaskan 


\section{Cinta Yang Palsu}

Sebab cinta adalah suci

Jangan sesekali dikhianati

Cinta sebenarnya hanyalah cinta dari-Nya

Buanglah rasa penasaran untuk mencobanya

Sebab cinta yang palsu

Adalah cinta yang menggunakan nafsu

Berbicara tentang pandangan pertama

Aku percaya dengan pernyataannya

Syaitan menghias semuanya menjadi indah

Sampai kita sendiri mudah kehilangan arah

Mungkin sebagian dari mereka meng-IYA-kan

Karena mereka sudah merasakan kekecewaan

Sebab cinta yang palsu selalu hadir

Disaat mereka terlena dengan perkataan

Selalu membuatnya semakin berfikir

Tanpa sadar kita masuk dalam permainan

Aku tahu cinta yang palsu seperti apa

Kamu takkan percaya jika aku katakan

Adalah cinta yang selalu bertanya kenapa?

Kenapa bisa?, padahal sudah aku katakan

Hubungan yang belum dihalalkan sudah sangat jelas

hanyalah palsu

Yang pastinya, itu hanya akan saling memuaskan nafsu

Maka jauhilah cinta yang palsu

Jika kamu ingin cintanya maka cintailah DIA 


\title{
Dekat Dihati
}

Ada yang berkata "Mustahil bersatu" Aku dan kamu kelak disatukan oleh waktu

Waktu itu yang hanya DIA yang tahu Dan orang itu aku berharap adalah kamu

Mereka berkata "Jarak masalahmu" Aku dan kamu tidak mempermasalahkan itu Jarak yang sangat jauh bukan problema Selama Do'a selalu tersampaikan pada-Nya

\author{
Dekat dihati \\ Karena kita saling mencintai \\ Dan tujuannya \\ Yang pasti menuju jalan-Nya \\ DIA tak pernah memberitahu \\ Dengan siapa dan di mana akan bertemu \\ Bertemu lewat Do'a \\ Dan bahagia berkat Do'a \\ Aku ingin dekat dihati \\ Tolong dekatkan kami
}

Semua itu adalah bagian dari Sebuah Rahasia

Tak perlu kita tahu, cukup kita dekati siapa penciptanya

\begin{abstract}
Jika kelak aku tak bisa bersama
Aku tahu, DIA lebih tahu dari semua

Semoga aku, kamu dan DIA selalu dekat dihati
\end{abstract}




\section{DIA dan Dia}

DIA adalah pengatur hidupku

Dan hanya DIA Penciptaku yang paling sempurna

Mungkin Dia hadir dalam hidupku

Tapi tanpa-Nya, aku takkan bisa merasa bahagia

Dia menjadikan rasa ini menjadi indah

Tanpa-Nya aku bukanlah siapa-siapa

Walau hanya diberi sedikit, cukup syukurilah

Agar DIA terus memberikan kasih-Nya

Dia dan dia, selalu tentang dia

Semua tulisanku bisa saja tentangnya

Tapi aku juga tak ingin melupakan-Nya

Karena-Nya aku selalu dicinta olehnya

Menjadi pelengkap dalam sebuah kehidupan

Melengkapi keimanan demi kesempurnaan

Tanpa adanya rasa yang penuh kekecewaan

Aku tahu itu adalah bagian dari kebahagiaan

Bersamanya mungkin salah satu keinginanku

Tapi semua terserah pada-Nya yang memberi

Jika Dia kelak tak bersamaku

Aku harus ikhlas menerima ini

Semoga DIA selalu menjaganya

Semoga DIA selalu memberi kemudahan padanya Dan semoga DIA memberikan yang terbaik untukku dan untuknya 


\section{DIA Lebih Mencintaimu}

Menelurusi kisah di masa lalu Akhirnya aku menemukan dirimu Aku berusaha untuk mendekatimu Sayangnya DIA lebih mencintaimu

DIA mengingatkanku dengan pesan Melalui ayat yang sudah tersirat Aku harus mengambil semua pelajaran Agar kedepan aku bisa selalu dekat

DIA lebih mencintaimu Dan dicintai DIA adalah indah Jika diri mu juga begitu Semoga kita selalu terarah

Dicintai oleh-Nya, Aku, merasa sempurna Sempurna karena selalu dicukupkan Dicukupkan dengan apa yang diberikan Dan itu adalah bukti nyata DIA sayang pada kita

DIA Lebih Mencintaimu Lebih dari cintaku kepadamu Jika kamu ingin dicinta olehku Maka cintailah yang menciptakan aku

Maaf dirimu bukan hal pertama Bukan berarti aku menjadikanmu yang kedua Hanya DIA alasan diriku ada Cukup dengan mencintai-Nya kita akan sempurna 


\section{Dia Yang Selalu Terluka}

Mungkin di mata kalian dia selalu lemah

Mungkin di mata kalian dia mudah patah

Tapi, pernahkah menyempatkan waktu mendengarkan

Bagaimana perjuangan seorang ibu ketika melahirkan?

Aku sedang tak ingin membahas tentang ibu

Karena terlalu luas jika aku menjelaskan hal itu

Yang aku ingin bahas adalah wanita yang selalu kalian lukai

Tanpa menggunakan perasaan, kalian mampu menyakiti

Aku duduk di pelataran kampus bagian administrasi Mendengar omelan, dia yang benci dengan seorang lelaki

Dia berkata "lelaki itu gak punya hati"

Dan dia merasa selalu tersakiti

Aku tersenyum ketika mendengarkan statement ini

Bagaimanapun, itu adalah senjata yang ampuh Agar dia sedikit bisa sedikit menenangkan diri

Walau sebenarnya memang sangat rapuh

Mengapa wanita selalu disakiti?

Apa karena, mereka mudah disakiti?

Apa karena, mereka mudah dikendalikan?

Ataukah, apa karena terlalu bawa perasaan?

Jika kau menilai mereka itu lemah

Sepertinya pernyataanmu itu salah

Jika dia memang lemah,

Bagaimana bisa dia betah? 
Selalu saja lelaki mempermainkan perasaannya Tak pernah berfikir bagaimana jika dikecewakan Selalu saja lelaki menganggap mereka mainannya Yang bisa menjadi tempat hiburan dikala bosan

Bukan hal yang mudah jika aku sendiri yang bersuara Karena wanita, tak mau belajar dari pengalaman Akan selalu disakiti oleh lelaki dan dibuat kecewa Tapi jika pilihan adalah alasan, tak bisa aku paksakan

\author{
Hai wanitaku, \\ Jangan lagi mau dipermainkan \\ Kalian harus kuat menghadapi kesendirian
}

Percayalah ini takkan berlangsung lama Jika kalian terus istiqomah dan bersama-Nya Aku tahu, kalian yang paling setia dalam cerita ini Tapi, aku tak ingin melihat kalian terluka lagi

Tapi jika kalian masih bertahan dengan sebuah kepalsuan Terserah itu pilihanmu, semoga DIA sesegera menyadarkan

“Wanita-wanita yang keji adalah untuk laki-laki yang keji, dan laki-laki yang keji adalah buat wanita-wanita yang keji (pula), dan wanita-wanita yang baik adalah untuk laki-laki yang baik dan laki-laki yang baik adalah untuk wanita-wanita yang baik (pula). Mereka (yang dituduh) itu bersih dari apa yang dituduhkan oleh mereka (yang menuduh itu). Bagi mereka ampunan dan rezeki yang mulia (surga)" 


\section{Diriku adalah Diriku}

Kelemahanku adalah kelebihanku

Jika kamu tak menerima, itu bukan masalah buatku Intinya itulah yang menjadi kelemahanku Jadi jangan kamu remehkan dan jatuhkan diriku

Mungkin mereka berkata terlalu rentan

Memang benar, rentan dengan perasaan Mencoba menjauh dan tak kembali menyentuh Sayangnya aku tak bisa dan sering kali terjatuh

Tulisan yang aku buat acap kali tak sama

Tulisan yang aku buat seringkali tentangnya Memang salah karena pandangan yang berbeda Memang salah jika semua isi hanya tentang dirinya

Tak peka dengan segala keadaan Membuatku menjadi rentan dengan perasaan

Tekad harus kuat dan penuh yakin Berbenah selalu untuk yang ku ingin Bersamanya mungkin keinginanku Tapi dengan-Nya lah jalan yang menjadi takdirku

Tak apa jika apa yang ku ingin tak bisa ku dapatkan Ingatlah DIA memberikan yang terbaik dari sebuah pilihan Apa yang di tuliskan oleh-Nya adalah keputusan Yang harus aku jalani dan harus aku lakukan

Hargai diriku, sebagaimana kamu menghargai dirimu Karena dengan menghargai kamu bisa lebih mengerti 


\section{Dirimu Begitu Indah}

Bagai bunga yang akan mekar

Semerbak harumnya menyebar

Pada dasarnya perempuan itu memang cantik Hanya saja mereka sering merasa kurang menarik

Ketakutan yang selalu mereka ciptakan sendiri Membuat mereka selalu berlebihan dengan diri

Jika kamu memang merasa cantik Jagalah dirimu layaknya barang antik Jangan sesekali diobral dengan potongan harga Aku yakin banyak yang mengantri untuk berbelanja

Karena kehormatan dari parasmu tidak ada harganya Janganlah kamu tawarkan kepada lelaki bermuka dua Tak banyak novel yang aku baca memiliki pembelajaran Tapi dari beberapa garis besar, aku bisa menyimpulkan

Disisi lain banyak dari kaumku yang memuji parasmu Janganlah kamu bangga, karena itu hanyalah pujianku Disisi lain juga banyak dari kaummu yang mencaciku Janganlah kamu bangga, karena aku sama sepertimu

Kamu cantik, iya benar kamu begitu sempurna Cantik itu relatif, jangan dulu kamu merasa paling berharga Sebab kesempurnaan itu hanyalah milik-Nya

Jika diri ini terlalu menuhankan parasmu Tegurlah aku karena bisa jadi, saat itu syaitan menguasaiku 
Jika diri ini terlalu memuji kecantikanmu Tegurlah aku karena bisa jadi, saat itu aku tak berdaya melihatmu

\author{
Dirimu Begitu Indah \\ Memang hanya DIA yang maha kuasa \\ Semua ciptaan-Nya akan selalu indah dipandang mata \\ Karena DIA pemilik semuanya \\ Jadi, dekati DIA dahulu sebelum kamu jatuh hati kepada \\ dunia yang tak berujung dan membuatmu mudah \\ kehilangan arah
}




\section{Dirimu Tak Bisa Memaksa}

Runyam kisah masa lalu ku Begitu juga dengan dirimu

Aku menerima itu

Begitu juga dirimu

Kamu membuat cerita berliku

Aku menikmati dengan jalan halu

Imajinasi meninggi seolah melayang

Hingga jatuh dan membuatku terkekang

Dirimu tak bisa memaksa

Untuk melepas dengan ikhlas

Dirimu tak bisa memaksa

Untuk menjadikanmu sebagai prioritas

Sudah aku katakan kepadamu

DIA, keluarga, dan sahabat adalah prioritasku

Sudah aku katakan kepadamu

Jangan samakan aku hanya karena masa lalumu

Dirimu tak bisa memaksaku

Untuk menjadi seperti yang dirimu mau

Dirimu tak bisa memaksaku

Untuk mengubah kehendakku atas semua keinginanmu

Dan dirimu tak bisa memaksa

Karena sejatinya hanya DIA-lah yang maha membolak-

balikkan hati manusia

Hempaskanlah semua pikiran dibenakmu seperti angin yang berhembus ditanah lapang 


\section{Do, and Hargai Prosesnya}

Belajar dari kesalahan, bukanlah hal yang mudah

Karena sering kali, hati pasti akan berbenturan Pilihan hidup, selalu saja membuat mudah resah Karena sering kali, bertentangan dengan perasaan

Mungkin kamu terlalu lemah dengan keadaan Sehingga, kamu sulit sekali menerima kenyataan Mungkin terlalu rapuh dengan masa lalu yang kelam Sehingga, dirimu terjatuh kedalam lubang yang dalam

Terlalu jauh langkahmu dalam mengambil keputusan Karena, selalu tak sesuai dengan kenyataan Tak pernah terfikirkan tentang kisah di masa lalu Karena bisa jadi, sumber masalah adalah itu

Berharap kepada-Nya adalah jalan terakhirmu Mungkin saja kamu salah dalam menetapkan pilihanmu

Semoga DIA mengampuni segala kesalahanmu Dan semoga, DIA memberikan jalan yang terbaik kepadamu

Terkadang hidup yang kamu ingin nikmati

Tak sesuai dengan apa yang kamu harapkan

Terkadang kemauan yang tak sesuai

Membuat pola kehidupan berantakan

Tapi apa karena itu, dirimu berhenti sampai di sini?

Tidak, kamu tak pantas untuk putus asa saat ini Tetap pandang tujuanmu dan jadikan itu pegangan Jangan patah semangat apalagi sampai kelelahan 
Jika kamu kelelahan, beristirahat sejenak

Dan kemudian, lanjutkan kembali langkahmu

Jangan sampai karena ini, hatimu menjadi retak

Dan akhirnya kamu pun kehilangan pecahan dirimu

Belajar itu perlu, asal kamu menggunakannya dengan baik

Mengekspresikan itu harus, asal kamu tahu batasannya Jangan sampai, karena ilmu kita melupakan-Nya

Dan karena asik berekspresi kita semakin jauh dari-Nya

Do and Enjoy The Process

Karena kamu akan lebih paham ketika hasil yang tak sesuai

Selalu memiliki maksud dan tujuan dibaliknya 


\section{Do'aku Untukmu}

Berjalan ditengah malam yang sunyi Aku berharap ada yang bisa menemani Tapi setelah jauh ku langkahkan kaki Aku baru sadar dengan kepergianmu

Teringat akan kata-katamu Yang berusaha mengingatkanku

Salahku, aku selalu menghiraukanmu Dengan harapanmu akan bisa membawaku

Membawaku kembali kepada jalan-Nya Yang membuatku lebih baik kedepannya Tapi diriku selalu saja tak mau merasakan Dengan teguran yang selalu kamu berikan

Do'aku untukmu Semoga DIA memudahkanmu

Dengan keistiqomahanmu

Semoga mulus semua jalanmu

Lilin yang kamu berikan dulu Memberi sedikit cahaya dijalanku Semoga aku bisa kembali kepada-Nya Dan terus patuh dengan perintah-Nya

Terima kasih dirimu, takkan aku lupakan semua perkataanmu

Do'a terbaik untukmu, karena sudah memberikan semua kebaikanmu Hanya DIA yang mampu membalas semuanya 


\section{"Hati" dan "Perasaan" adalah satu}

"Hati" adalah pemberian dari-Nya karena DIA juga cinta kepada kita Dan "Perasaan" adalah bonus dari-Nya ketika kita benar-benar mempelihara hati untuk-Nya Jadi, janganlah sesekali kita mempermainkan-Nya apalagi sampai membuatnya tersayat karena luka

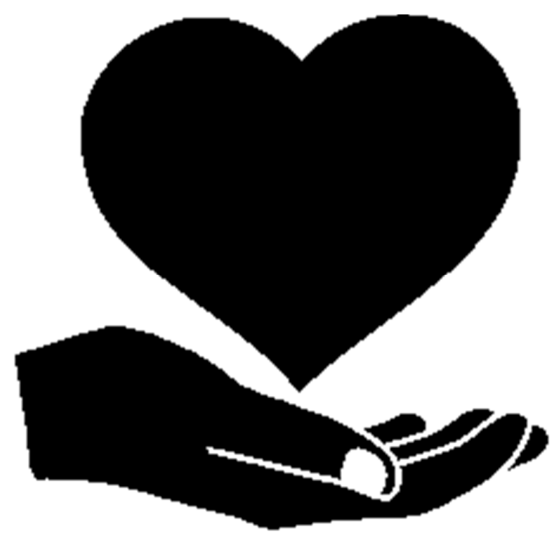




\section{Dua Insan Yang Merepotkan}

Sudah aku katakan, hubungan itu tak boleh

Tapi, dari mereka masih saja mau mengikuti

Sudah aku katakan, jangan lagi kau menoleh

Tapi, dari mereka sudah saling memberi hati

Sebab Dua Insan ini adalah hal yang saling tarik- menarik Layaknya magnet dan besi, tak mudah untuk dipisahkan Aku berkata, jangan kalian bangun hubungan yang pelik Karena itu semua, hanya akan melukai dan mengecewakan

Tapi entahlah, itulah keputusan mereka Yang ingin melakukan demi sebuah kekecewaan Terserah mereka, semua akan ada konsekuensinya

Setidaknya diri ini tak berhenti mengingatkan

Bagaimana bisa terjadi?, kalau tak ada sebab Sedangkan mereka menjadikan diri sebagai penyebab

Yang satu menggoda Akhirnya yang lain tergoda

Kecewa dan sakit hati akan selalu ada Apalagi dalam sebuah hubungan yang belum resmi Kalau bukan dia yang membuat, sudah pasti dia Aku tak menyalahkan, tapi mereka selalu tak mengerti

Memang bukan urusanku untuk ikut campur

Tapi mau sampai kapan mereka seperti itu

Sampai semua batu didunia menjadi kapur Takkan pernah selesai masalah jika terus begitu 
Aku selalu menjadikan kata-kata sebagai senjata Bukan untuk menyerang, tapi untuk mengingatkan

Hanya saja mereka tak pernah mau menata

Demi kehidupan yang endingnya adalah kebahagiaan

Aku tak melarang, tapi mereka memang sulit diatur

Bagaimana lagi? Itulah namanya hubungan prematur Yang memutuskan akan salah dengan jalan meninggalkan Yang diputuskan menerima dengan jalan ikhlas dan butuh waktu untuk merelakan

Terjebak diantara 2 kutub yang terpisahkan Menyulitkan seseorang untuk saling melupakan Bingung, harus bagaimana lagi cara menyelesaikan Mungkin hanya kekecewaan yang bisa menjelaskan

\author{
Dua Insan Yang Merepotkan \\ Jika mereka saling mengikrarkan \\ Maka beranikan diri untuk meng-Akad-kan \\ Bukan lewat omongan singkat atau sebuah bualan
}

Hubungan itu hanyalah sebuah kepalsuan Jangan ada lagi luka, dibalik kekecewaan Cintailah karena itu penyempurna keimanan Bukan dibina hanya karena cinta-cintaan

INGATLAH!!!

Itu bukanlah sebuah permainan, yang harus dinikmati Yang Pria Hargailah dan jaga wanita Yang Wanita jaga diri kalian dari diskon murahnya cinta 


\title{
Dunia Tak Dipuji
}

Apa yang kamu punya di dunia ini

Belum tentu bisa membantumu suatu hari nanti

Apa yang kamu banggakan di dunia ini

Belum tentu bisa menyelamatkanmu di akhirat nanti

Apa yang kamu cari dari dunia ini

Belum tentu bisa memuaskanmu nanti

Apa yang kamu tangisi didunia ini

Belum tentu bisa menangisimu saat mati

DIA tak pernah memuji dunia ini

Utusan-Nya pun tak pernah memuji

Ketika kamu bangga dengan duniamu

Ingatlah satu hal, yakni kematianmu

Kita boleh berencana buat dunia kita kedepannya Tapi, kita pasrahkan juga rencana itu kepada-Nya Jangan terlalu percaya diri dengan rencana Yang belum kita tahu bagaimana nantinya

\author{
Percuma dunia kita miliki \\ Kalau iman gak punya sama sekali \\ Percuma hidup bahagia di dunia \\ Kalau akhirat kita sengsara
}

Think again

If you do something

Dan kemudian kamu menilai itu mudah Ingatlah tidak ada yang mudah di dunia ini 
Awal senang belum berarti ending bahagia

Awal susah belum tentu endingnya akan bahagia Di mana kamu mendapat tantangan, majulah tanpa ragu

Karena disitu kamu diuji, seberapa sabar dirimu

Jangan berpikiran, kamu akan terus merasa bahagia Jangan berpikiran, kamu akan terus hidup selamanya

Semua ini hanyalah milik-Nya

Istigfarlah bila kamu sadar hal itu salah Bersyukurlah bila apa yang kurang itu atas kehendak-Nya Terimalah dengan apa yang kamu punya saat ini Karena DIA tak pernah meminta izin jika ingin mengambilnya kembali

Ketika kamu mencari akhirat, Maka perihal dunia yang akan kamu dapatkan Bukan untuk mengahalangimu beribadah Tetapi, itulah pilihan yang harus kamu ambil DUNIA ataukah AKHIRAT

"Ingatlah, Dunia Ini Akan Berguna Untuk Orang-Orang Yang Berfikir"

(Ustadz Adi Hidayat Lc. MA) 


\title{
Hadirmu
}

Melihat tawamu

Mendengar ceritamu

Terlihat jelas dimatamu

Warna warni indahmu

\begin{abstract}
Kamu, selalu ada dihatiku
Setelah DIA dan orang tuaku

Walaupun tak bisa berjumpa denganmu

Tapi selalu aku rasakan kehadiranmu

Maaf jika namamu selalu ku sebutkan Aku sebutkan namamu saat bersama-Nya

Aku yakin rasa ini takkan dikecewakan Karena ini adalah bagian ujian dari-Nya
\end{abstract}

Begitu lembut caramu meluluhkanku Begitu hangat caramu mencintaiku

Terima kasih atas warna warni darimu Yang kamu beri begitu tulus kepadaku

Siapa yang tahu takdir tuhan

Yang telah menghadirkan dirimu

Kisah cintaku sungguh menakjubkan

Karena kamu adalah penyeimbangku

Hadirmu menjadi pelengkap dalam hidupku

Semoga DIA selalu memberkahi dirimu

Dan selalu memberi kemudahan padamu 


\title{
Halalkan Atau Tinggalkan
}

Aku bertemu dirimu setahun silam

Terlihat jelas senyum dan wajah cantikmu Aku hanya bisa menyimpan dalam-dalam Karena aku takkan pantas jika bersamamu

\author{
Duniaku teralihkan karenamu \\ Akalku terfikirkan tentangmu \\ Tapi, apa hak dan kewajibanku \\ Jika aku menitip rasa ini padamu
}

Jujur, aku sangat menyukaimu

Tapi, bagaimana cara ku sampaikan ini kepadamu

Aku rasa, cukup aku simpan saja cintaku

Jika memang takdir pasti DIA memilihku untukmu

Halalkan Atau Tinggalkan

Bukan perkara yang mudah melainkan hal sulit

Jika aku meninggalkan

Pasti akan ada hal yang akan membuat terlilit

Aku meninggalkanmu

Bukan berarti aku tak memiliki hati

Aku meninggalkanmu

Karena aku tahu, kamu bukan untukku saat ini

Jika DIA memudahkan

Kelak kamu, akan aku halalkan

Jika DIA memudahkan

Tidak akan ada sebuah kekecewaan 
Dirimu bagaikan mahkota raja

Yang pas disatu kepala saja

Sekalipun orang lain memaksa

Ukurannya takkan pernah sama

Berbicara tentang halalkan

Sudah pasti akan ada pertanggung jawaban

Bukanlah sekedar bualan

Jika sudah terikat haruslah dijalankan

Berbicara tentang tinggalkan

Sudah pasti akan ada yang di kecewakan

Bukan berpihak pada perasaan

Jika sudah yakin jangan lagi disalahkan

Cintailah DIA yang maha memiliki

Cintailah DIA yang sudah memberi

Memiliki apa yang ada pada dirimu

Memberi apa saja yang kamu mau

\section{Yakinlah satu hal, \\ Bahwa pilihan-Nya}

Adalah yang terbaik untukmu, keluargamu dan seluruh aspek di dalam kehidupanmu

Jika aku sudah mampu, kamu akan aku halalkan Untuk menjadi ibu dari malaikat kecilku

Tapi, jika aku belum siap, kamu harus siap aku tinggalkan Bukan karena aku ingin menyakiti, aku hanya tak ingin membuatmu berdosa lagi 


\section{Halalkanmu}

Tak pernah tahu apa isi dihatimu

Tak pernah tahu apa yang kamu mau

Kamu wanita penuh rahasia

Seperti dalamnya samudera

Mencintaimu, adalah salah satu cita-citaku

Bersamamu adalah salah satu keinginanku

Walau aku tak tahu, apa kamu juga mencintaiku Dan akupun tak tahu apa kamu mau bersamaku

Dengan tujuan baikku Ingin ku halalkan dirimu

Dengan janji suciku

Akan ku jaga selalu rasamu

Semua terserah pada-Nya

Karena DIA sudah menuliskan semuanya

Bukan berharap untuk bersama

Apapun pilihan-Nya aku akan tetap menerima

Seperti kata mereka

Menjadi imam bukan hal yang mudah

Aku harus tetap percaya

Karena diri ini harus terus berbenah

Aku ingin menjadi seorang yang DIA inginkan Bukan menjadi diri yang selalu kamu banggakan Karena hidupku, hidupmu atas kehendak-Nya 


\title{
Hanya Rindu
}

Sebenarnya aku hanya ingin mengungkapkan Apa yang sebenarnya sedang aku rasakan

Tapi selalu saja, aku tak pernah bisa Berbicara dengan kepercayaan diri yang ada

Bukannya aku takut akan perasaan itu Hanya saja aku tak ingin memaksa hatimu Bukannya aku tak berani berbicara padamu Hanya saja aku membisu saat diri ini bersamamu

\author{
Hanya Rindu \\ Itu menurutku \\ Sampai jumpa dirimu \\ Aku tunggu kedatanganmu
}

Ayahku mengatakan kepadaku

Jika merindu sampaikanlah kepada-Nya

Aku tak pantas bersedih dikala hadirnya rindu

Menurutku dengan do'a, aku bisa menenangkan itu

\author{
Hanya rindu \\ Mungkin hanya itu \\ Walau sedikit membuat pilu \\ Setidaknya sudah aku katakan kepadamu
}

DIA membuat semua menjadi indah

Walau sebenarnya aku sendiri yang membuat susah Aku rindu dirimu, aku berjanji takkan membuatmu patah 


\section{Harapan Disaat Senja}

Tak terasa senja telah berlalu

Dan bulan pun mulai menggerutu

Langkahku semakin jauh darimu

Terjatuh karena larut ke dalam masa lalu

Pernahkah kamu berfikir tentangku

Disaat diriku jauh dan terjatuh

Aku rasa, kamu sama dengan senja itu

Yang hadir sesaat, lalu pergi menjauh

Aku tahu akan hadir kembali

Tapi percayalah, takkan seindah ini

Aku tahu malam ini akan nikmat dengan segelas kopi

Tapi ingatlah, tanpa gula, kopi takkan bisa dinikmati

Diriku adalah diriku, jangan kamu samakan aku dengannya Mencintaimu adalah hal yang tersulit dalam hidupku Bukan takut, hanya saja aku tak bisa untuk selamanya Hanya bisa berharap semoga DIA selalu memudahkanku

Alunan musik mengiringi tidurku

Seakan larut dalam suasana malamku

Tak sanggup jika aku terus memaksa mencintaimu Walau dalam mimpi dirimu selalu menganggu

Aku percaya, senja yang akan hadir tak seindah ini Tapi aku akan berusaha menghias dengan caraku sendiri

Aku yakin, tanpa kopi malam ini akan terasa sunyi

Tapi tenanglah, takaranku selalu pas untuk dinikmati 


\section{Harapan disaat senja hadir \\ Selalu saja orang dibuat berfikir \\ Mereka tak pernah menyangka \\ Bahwa dunia hanyalah fatamorgana}

Berdo'a kepada-Nya adalah sebaik-baiknya pengharapan

Walau hasilnya selalu saja tak sesuai yang diharapkan Aku yakin, DIA mendengarkan apa saja yang aku sampaikan Walau terkadang aku meminta tanpa menjaga kelakuan

$$
\text { Pelan tapi pasti }
$$

DIA akan memberikan yang aku pinta

Walau aku tahu belum tentu diberi di sini

Yang aku tahu DIA tak pernah mengingkari janji-Nya

$$
\text { Hai senja, }
$$

Maukah kau menemaniku sampai bulan hadir malam ini?

Aku harap "ya" jawabanmu

Terima kasih atas kenangan yang kau hadirkan

Semoga yang baik bisa dikenang

Dan yang buruk bisa segera hilang 


\section{Hargai Dan Jaga Dia}

Dia adalah tulang rusuk pelengkap

Dia adalah penyempurna keimanan

Tak patut jika kamu tak menjaga sikap

Tak pantas jika kamu berani merendahkan

Dia adalah penerang dibalik gelapnya kehidupan

Cinta dan kasih sayang sungguh ikhlas dia berikan Darinya terlahir benih-benih yang berakhlak mulia Sangat suci, sehingga tak ada yang bisa mengotorinya

Dan dia adalah Seorang Wanita

Dia diberikan salah satu anugerah dari-Nya

Rahim adalah salah satu yang dititipkan oleh-Nya Karena DIA tahu, dia mampu bertahan dibalik tekanan Karena DIA tahu, dia akan selalu kuat dalam kesabaran

Apa hak kamu, menjaganya dengan sebuah hubungan?

Apa mengambil adalah cara menjaga kepercayaan? Kamu tak berhak, mengambil dengan dasar sebuah ikatan Jika yang halal saja, kalian menolak untuk mengakadkan

Sekalipun kamu menyakitinya Ingatlah satu hal, dia akan selalu kuat menghadapinya Jika kamu masih merusak kehormatan Ingatlah, dari mana asal kamu dilahirkan

Dia bukanlah tempat pelampiasan nafsu belaka Tapi tempat menyempurnakan ibadah kepada-Nya 
Hargai dia dengan segala kemampuannya

Hargai dia dengan segala keterbatasannya

Jaga dia dengan cara yang benar dan cara yang sesuai

Bukan membangun hubungan yang ujungnya akan bertikai

Jaga dan Hormati dia sebagai saudari muslim kalian

Katakan kepadaku wahai wanitaku

Jika aurat kalian dilecehkan

Jika syariat kalian dijatuhkan

Dan harga diri kalian dipermainkan

Aku siap melindungi kalian

Bahkan nyawa ini akan aku jadikan taruhan

Salam dariku,

Saudara muslim kalian 


\section{Hati itu Satu}

Sebab hati itu satu

Hanya untuk satu hati

Jika dipaksakan memuat dua hati

Aku tak percaya itu bisa bersatu

Kita melakukan sesuatu berdasarkan suara hati

Jika itu buruk maka hati akan berkata buruk

Dan Jika itu baik maka hati akan berkata baik

Tidak bisa kita paksakan apalagi kita khianati

Saking berperannya hati,

Hampir semua aspek kehidupan selalu berhubungan

Saking pentingnya hati,

Sekali dikhianati dia akan susah untuk mempercayakan

Mereka sering bertanya

"Apa kamu mencintaiku?"

Dalam hidupku semua sama

Memiliki posisi masing-masing dalam hatiku

Tak berlebihan apa lagi sampai terlupakan

Akan selalu berantakan jika berlebihan

Maka dari itu, jagalah selalu hatimu

Jangan berikan, jika dirimu belum mampu

Dalam mencintai, hati adalah unsur utama

Beradu dalam kesetiaan untuk sebuah kebahagiaan

"Mengapa hati yang menjadi unsur utama?"

Karena hati, selalu peka dengan lemahnya perasaan 
"Manusia adalah makhluk sosialkan?"

Jadi berbuat baiklah selagi kamu bisa

Karena ketika hatimu baik, baiklah keseluruhan Jika hatimu tak baik, maka tak baiklah semuanya

Menjaga perasaan orang lain itu sangatlah penting Janganlah masuk dalam kehidupan orang lain Jika kamu tak tahu jalan untuk kembali pulang Kamu akan tersesat dan terseret hingga ujung jalan

Terlalu luas jika aku diperintah untuk menjelaskan Jika hatimu selalu kamu pasrahkan kepada-Nya Kelak kamu akan pandai dan peka dalam merasakan “Jika DIA saja kamu abaikan, bagaimana dengannya?"

Jangan terlalu percaya dengan bualan Yang selalu meluluhkan hati dan perasaan Karena itu hanya bersifat sementara dan akan hilang Ketika hilang, dia takkan datang untuk kembali pulang

Kuatkanlah hatimu dengan penuh kesabaran Serahkan semua kepada-Nya

DIA-lah pemilik hati

Jangan merasa tinggi hati, jika ingin dicintai Jangan meremehkan masalah ini Jika kamu tak ingin lagi dilukai

Maka dekati DIA jika kamu inginkan hatinya Dan yakinkan DIA jika kamu benar mencintainya 


\section{Hidayah}

Aku, kamu dan mereka adalah ciptaan-Nya Jangan bangga dengan apa yang sudah dititipkan

Aku, kamu dan mereka adalah hamba-Nya Jangan bangga dengan apa yang sudah dikerjakan

Terkadang kita sering sekali menutup diri Menutup diri dari cerita tak berujung dan penuh dilema

Terkadang kita sering sekali lupa dengan diri Lupa diri dari pekerjaan dunia yang sifatnya sementara

Aku, kamu dan mereka tak bisa memberi hidayah Sebab hanya DIA yang bisa memberi agar bisa berubah Aku, kamu dan mereka adalah jembatan kehidupan Sebab hanya DIA yang mampu memberikan ketenangan

Hidayah adalah hal terindah dalam hidup Tanpa hidayah kita akan menjadi manusia yang tertutup

Tertutup dari semua hal untuk lebih mengenal-Nya Dan menjadi manusia yang kaku dengan kehidupan dunia

\section{Dunia hanyalah fana}

Berhati-hatilah dirimu dalam berjalan Jangan sampai terlena Karena ini ujian terbesar dalam kehidupan

Marhaban Hidayatullah

Bimbing kami selalu di dalam jalan-Mu

Jangan biarkan kami berada di dalam fitnah bernama Dunia 


\title{
Hijrahku
}

Mereka bertanya "Bagaimana hijrahku?"

Wallahi, hanya DIA yang tahu prosesku

Aku tak bisa menjawab itu

Karena aku masih butuh waktu

Tak ada yang singkat dalam sebuah cerita Jika kita hanya membaca tanpa memahaminya Aku tak tahu "apakah aku bisa memotivasimu"

Dengan kata-kata pedas sebagai senjataku

Hijrah itu mudah

Bagi mereka yang mau berubah Inti dari hijrah

Adalah kita harus tetap istiqomah

Seperti membangun sebuah karya

Perlahan tapi pasti demi hasil

Dengan proses yang cukup lama Janganlah terlalu fokus pada hasil

Hijrahku sangat singkat

Kehidupanku terasa sangat cepat

Ambilah pelajaran yang bisa kamu gunakan Jangan berlagak tak peka dengan semua keadaan

\author{
DIA yang membantuku \\ Tanpa-Nya, aku bukanlah siapa-siapa \\ Dan tanpa-Nya, aku takkan bisa kembali kejalan-Nya
}




\section{Hujan}

Dia datang dengan sebuah peringatan Dan aku selalu menikmati setiap tetesan Kehadirannya membuatku sedikit tenang Tenang dengan semua yang dikenang

Dia hadir diwaktu yang tepat Disaat aku memang membutuhkan Itulah tanda dari-Nya agar aku taat Disaat aku sedang lemah dalam iman

Senyuman yang selalu mengawali hariku

Tenang ku rasa saat aku bisa bersamamu DIA menghadirkan mentari dibalik awan mendung Agar diriku bisa kembali berjalan tanpa tersandung

Sudah reda tetesan yang DIA berikan Aku beranikan diri untuk melangkahkan DIA selalu memberi tanpa mengharapkan Tapi tetap saja aku selalu menghiraukan

Semoga aku berada di dalam lindungan-Nya Agar diri ini selalu terjaga dari segala godaannya Lindungan yang paling aman menurut ku Godaan yang bisa kapan saja merusak ku

DIA menghadirkan hujan sebagai pertanda

Pertanda bahwa DIA sangat menyayangi kita Maka jangan lupa untuk selalu bersyukur dan berdo'a Agar kita selalu bersama-sama menuju jalan-Nya 


\section{Ibu}

9 bulan aku berada di dalam perutmu

2 tahun lamanya engkau menyusuiku

Tanpa beban Kau sangat bahagia atas kehadiranku Walau terkadang aku tak pernah mengerti dengan dirimu

4 tahun setelahnya, Engkau memasukkan aku ke jenjang pendidikan

Selama 12 tahun, aku belajar tapi masih saja, Diriku tak pernah mengerti arti sebuah kehidupan

4 tahun kemudian, aku memutuskan untuk melanjutkan pendidikan

Karena aku tergiur dengan gelar yang sering aku banggakan

2 tahun kemudian, aku memutuskan untuk menikah dan meninggalkanmu

Tanpa beban, Kau mengikhlaskan diri ini dengan senyumanmu yang sangat indah

Tapi dengan senyuman itu, masih saja aku terlihat kaku dan bertindak keras kepadamu

Engkau adalah pelitaku yang selalu menerangi jalanku

Dibalik kegelisahan, Engkaulah yang meyakinkanku

Engkau adalah lilin kecil yang selalu menuntunku

Dibalik kesusahan, Engkaulah yang selalu mengingatkanku

Dengan apa aku harus berterima kasih? 
Hartaku saja tak cukup

Waktuku saja takkan mampu

Takkan cukup membalas semua kebaikanmu

Dan Takkan mampu menemani sampai akhir hayatku

Aku tahu ridho-Nya ada padamu

Do'amu takkan tertolakkan

Kasihmu takkan terbalaskan

Aku mohon kepada-Mu jagalah dirinya selalu

Aku tak tahu tulisan apa lagi yang mampu mengekpresikan rasa terima kasihku ini

Sajak yang ku buat, takkan mampu membalas kebaikannya Lagu-lagu yang kuciptakan belum tentu bisa membuatnya bahagia

Hanya Do'a yang bisa ku berikan dan tak lebih dari itu

Ampuni aku Ya Rabb....

Atas semua kesalahanku, yang telah aku lakukan padanya

Semoga aku terus bersamanya sampai akhir usia

Dan kelak aku bisa bersamanya di syurga milik-Mu

Dear Ummi

This is from your son

May Allah always protect you, Always forgive me and you and give you Jannah

Hayati Ya Mama

Aamiin 


\title{
Imajinasi
}

Melayang jauh diantara angan dan cerita Memikirkan jalur yang berbeda dengan dunia Memilih dan memilah semua cerita bahagia Menyentuh tanpa harus membuat terluka

DIA memberikan rasa Cinta

Karena Muhammad adalah Kekasih-Nya Seorang sosok yang berbeda Yang selalu merindu berjumpa dengan umatnya

Tak ada tokoh yang bisa aku imajinasikan Semakin tinggi cerita, semakin jauh perjalanan DIA menurunkan sebaiknya pengajar Muhammad adalah penerang layaknya cahaya fajar

Mencakup semua ras umat manusia Muhammad hadir sebagai penuntun kehidupan dunia Walau terkadang banyak yang tidak menyukainya Berkat-Nya aku, kamu dan mereka bisa mencintainya

Imajinasi tak terbatas ingin berjumpa denganmu Wahai kekasih Allah, yang selalu di rindukan kehadirannya Aku tahu dirimu juga merindukan kami sebagai umatmu Semoga kami bisa bersama dirimu di dalam jannah-Nya

\author{
Engkau bagaikan pelita \\ Dibalik gelapnya jalan kehidupan \\ Allahumma sholli alaa Muhammad wa alaa ali Muhammad
}




\section{Iman}

Sebuah kata bermakna yang harus dimiliki

Tak semua bisa mengerti apalagi memahami

DIA menyampaikan melalui kekasih-Nya

Agar kita bisa belajar dan memahaminya

Terkadang diri kita sering sekali ego dalam berfikir

Hanya bisa berfikir tanpa menggunakan dzikir

Terkadang diri kita sering sekali berlaku sombong

Hanya bisa sombong padahal omong kosong

Menjadi manusia yang sempurna mudah sebenarnya Ikhlas sebagai dasar dan sabar sebagai rasa syukurnya

Jika diri kita lupa karena kehidupan dunia Cukup ingat bahwa kita hanya seorang hamba

Seorang hamba akan rela melakukan apapun Jika kita saja mengabaikan DIA sebagai penuntun

Dan terus beragumen dibalik gelapnya dunia Apakah pantas kita mengharap Syurga milik-Nya?

Iman adalah

Sesuatu yang tak terlihat namun harus kita miliki Iman adalah

Sesuatu yang mengikat sampai kita bertemu Sang ilahi

Jagalah dan Kuatkan selalu imanmu

Karena iman tak terlihat jadi jagalah selalu dari mereka yang terlihat dan jaga selalu dari mereka yang tidak terlihat 


\section{Islam Itu Indah}

Islam itu sangatlah indah

Islam adalah agama yang selalu menyayangi

Hati-hati jika tak tau ke mana arah

Karena ini bukanlah sebuah teka-teki

Mereka sering berkata bahwa Islam itu terbatas

Selama aku hidup, aku selalu merasa bebas

Sebab mereka selalu saja menilai dan berbicara

Dengan bahasa mereka yang tergolong biasa

Sebanyak apapun mereka menjatuhkan Islam

Percayalah Islam takkan mudah jatuh begitu saja

DIA selalu melindungi Islam sampai berpindah alam

Jika kamu tak tahu apa itu Islam, lebih baik diam saja

My Prophet Muhammad told us, Islam adalah sebuah pedoman kehidupan

Tidak bagi mereka yang selalu haus Haus dengan yang namanya ketenaran

Jika ada yang berkata Islam itu teroris Mungkin mereka tak tau siapa yang teriris

Sebab Islam adalah sebaik-baiknya agama Bersiaplah karena selalu ada yang menyerangnya

Mereka berlomba menjatuhkannya

Dan mereka berlomba menginjaknya

Tapi percayalah Islam akan selalu kuat bersama-Nya 


\section{DIA memberi kita pilihan Mendatangkan Muhammad, sebagai suri tauladan}

Islam bukanlah sekedar agama melainkan Pedoman Hidup untuk membawa kita menuju jalan-Nya 


\section{Jaga Dia Di sana}

Ya rabb, aku titip dia pada-Mu

Aku mohon jaga dia selalu

Aku tak bisa melihatnya

Hanya ENGKAU yang mampu, maka sampaikanlah salamku

Aku tak berharap banyak padanya

Karena hanya ENGKAU sebaik-baik pengharapanku

Banyak waktu yang ingin aku bagi bersamanya Menikmati indahnya sunrise dan sunset di sana

Tapi bukan saatnya jika aku terus memaksa Memberi perkataan manis hanya untuk dicinta

Aku tak tahu bagaimana rupanya

Aku tak tahu bagaimana perasaannya

Yang aku tahu cara pandangnya

Dan aku tahu hanya ENGKAU yang dia cinta

Jika diri ini terus menggumam dibalik kesendirian

Maka, akan hadir sebuah rasa kekecewaan

Jaga dia untukku,

Jika memang dia bukan untukku

Maka mudahkanlah dia untuk selalu bersama-Mu

Aku mohon jangan pernah tinggalkan dia

Sebab rapuhnya perasaan membuatnya mudah terluka 


\section{Jalanku}

Aku memaksa kaki untuk slalu bergerak

Tapi sayangnya aku selalu saja tak bisa

Di dalam benak mulai terbayang akan kehidupan kelak Tapi sayangnya diriku tak pernah yakin untuk mencoba

Orang-orang sekitar mengatakan kepadaku "Mengapa kamu selalu melakukan hal tak perlu?"

Bukannya aku mengabaikan pernyataan itu Hanya saja diriku, selalu merasa tak mampu

Tak mampu menanggapi semua pernyataan mereka Tak mampu menjawabnya dengan waktu yang singkat Aku masih butuh waktu untuk semua yang telah ada Dan berusaha menjalankannya agar bisa menjadi taat

Kenangan yang muncul disaat aku tak membutuhkan Dosa-dosa yang ku ingat disaat aku ingin melupakan Membuatku sering sekali bertabrakan

Dengan lemahnya perasaan

Ketika aku melakukan dosa Ayat-ayat-Nya selalu berputar dikepala

Apa itu adalah teguran dari-Nya Untuk membawaku kembali kejalan-Nya?

Dahulu aku hanya merasakan indahnya perbuatan Yang aku paksakan dengan sedikit kotornya perasaan

Dahulu sering sekali aku terjatuh tapi damai kurasa Padahal sudah jelas dia membisikkan perbuatan dosa 
Perbuatan yang akan membawaku masuk kedalam jurang kepedihan

Perbuatan yang akan membawaku masuk kedalam jurang keterpurukan

Sekarang aku paham, Apa keyakinan yang harus aku percaya Sekarang aku tahu, Apa tindakan yang harus aku lakukan

Walau sebenarnya perjalanku terasa lama Dan waktuku kembali terasa amat singkat Aku akan berusaha menjadi manusia yang berguna Bukan orang hebat namanya, jika selalu tak taat Don't stop to always giving itu,
You can't change everything, If you still quite

Selalu berbenah adalah kunci Dengan proses yang harus dijalani

Dengan Basmallah aku awali Dan dengan Hamdallah aku akhiri

Semoga semua bisa termotivasi Setidaknya aku masih bisa berguna 


\section{Jangan Larut}

Aku kamu dan dia sama

Tak ada yang membatasi diantara kita

Aku kamu dan dia berbeda

Berbeda karena kepala kita tak seirama

Seandainya kita mencapai itu

Kita akan mudah untuk menyatu

Sangat disayangkan batas kita miliki

Roda yang berputar pasti akan berhenti

Nikmati alur hidup yang DIA beri

Jangan sampai kita lupa dengan semua ini

DIA menjadikan kita berbeda-beda

Karena DIA tahu suatu saat kita akan bersama

Berbeda jalur pemahaman

Jangan jadikan itu perbedaan

Justru air tak pernah membedakan

Dari mana asal dan kemana tujuan

Aku kamu dan dia adalah milik-Nya

Jangan larut apalagi sampai putus asa

Karena putus asa bukan sebuah keputusan

Melainkan sebuah jalan persimpangan

Persimpangan yang harus dipilih

Agar kita tidak larut di dalam dunia

Yang sifatnya hanya sementara 


\section{Jodohku \\ "Assalamu'alaikum jodohku," "Bagaimana kabarmu?" \\ "Semoga baik-baik saja dirimu"}

Aku, hanyalah seorang yang penuh dengan dosa Aku, hanyalah seseorang yang selalu berbuat dosa Aku harap kamu bisa menerimaku yang tak sempurna Dan dirimu ada, tak lain tak bukan sebagai penyempurna

Untukmu yang sedang menjaga diri untukku Aku harap DIA tak salah memilihku sebagai pendampingmu Do'a yang selalu aku panjatkan, semoga tersampaikan Agar DIA selalu memberikan dirimu kemudahan

Untukmu yang sedang menjaga kehormatanmu untukku Jagalah kehormatan yang sudah DIA titipkan Jangan sesekali rusak hanya karena cinta-cintaan

Untukmu yang sedang menjaga hati untukku Cintailah DIA selalu, jangan sesekali kamu menduakan-Nya

Dan untukmu yang sedang mencari ridho-Nya Aku memang tak sempurna Kekuranganku cukup banyak Dan kelebihanku tak banyak

Semoga kelak kita dipertemukan

Di waktu yang tepat,

Entah di mana di suatu tempat, Yang pasti pilihan-Nya adalah pilihan yang tepat 


\section{Jodohmu}

Kelak akan ada suatu masa

Aku, menerima undangan darimu

Sejujurnya hatiku tak kuasa

Tapi aku harus menerima itu

DIA, yang menentukannya

Siapa yang berhak bersamamu

Jodohmu, adalah pemberian-Nya

Dan aku tak bisa egois kepadamu

Kelak, akan ada suatu waktu

Aku, menerima kabar gembira darimu

Kabar tentang bahagiannya keluargamu

Yang dahulu pernah aku rencanakan bersamamu

DIA, yang memberikannya

Siapa yang sanggup mengubahnya

Jodohmu, adalah ketentuan dari-Nya

Dan aku tak bisa memaksa untuk bersama

Terimalah itu, walau aku tak bisa bersamamu

DIA menghadirkan CINTA karena DIA juga CINTA kepadamu

Wallahi, kebahagian sebenarnya adalah, Ketika kamu bersyukur dengan semua pemberian-Nya

Dan Menerima semua yang menjadi kehendak-Nya 


\section{Jomblo Dan Pacaran}

Jomblo hanyalah sebuah status

Untuk mereka yang tak punya pasangan

Pacaran hanyalah sebuah status

Untuk mereka yang punya pasangan

Aku selalu mengabaikan tentang ini

Sebab ini bukanlah masalah utama

Tapi, dari mereka selalu saling meyakini

Bahwa ini adalah sebuah problema

Mereka yang jomblo selalu dicaci

Mereka yang pacaran selalu mencaci

Seolah jomblo adalah warga kelas dua

Dan pacaran adalah warga kelas pertama

"Apa di dalam hubungan, itu yang jadi masalah?"

Sudah jelas ini adalah hubungan yang salah

Mereka bilang lelah disakiti

Tapi, masih saja tetap dijalani

Entahlah, semua selalu saja rumit

Karena, mereka yang membuat sulit

Terlilit dalam lingkaran batas

Membuat mereka sulit untuk melepas

Mereka akan terus menjadikan ini permainan

Karena hubungan ini hanyalah sebuah kepalsuan

Yang sengaja dibuat indah oleh hiasan-hiasan syaitan 


\title{
Kamu
}

Kamu,

Adalah anugerah terindah dalam hidupku

Mencintaimu seutuhnya, Adalah salah satu cita-citaku

Kamu,

Adalah penggalan do'a yang aku panjatkan kepada-Nya

Dan Kamu,

Adalah objek yang aku jadikan bahan penelitian

Guna melengkapi kesempurnaan imanku dan imanmu

\author{
Rindu, \\ Kata mereka itu berat, \\ Ya, Memang berat, bagi mereka yang tak mampu, \\ Tak mampu menahan beratnya rindu
}

Menurutku, istiqomahlah yang paling berat

Bukan bualan dan cinta sesaat saja yang berat

Jika aku ditanya "kamu tak rindu padaku?"

Jujur saja, Aku rindu kepadamu

Tapi maaf, kamu tak perlu untuk tahu

Dan akupun tak perlu mengatakan rindu itu

\author{
DIA memberikan rasa \\ Karena DIA-lah pemilik rasa
}

Cukup DIA yang tahu jika diri ini merindu padamu

Aku hanya tak ingin rindu ini, menjadi dosa untukmu

Lewat lantunan do'a disetiap sujudku

Semoga DIA selalu menjagamu dan memberi kemudahan kepadamu 
Aku tahu, belum halal bagiku jika sekarang aku memaksa diri untuk mencintaimu

Aku tahu, rasa rindu ini takkan tersampaikan jika aku tak mengatakan kepadamu

\section{Diam,}

Adalah cara mencintaiku

Tak penting jika rasa ini aku sampaikan kepadamu

Yang saat ini belum halal untukku

Semoga kamu tetap bersabar di dalam ke-isqomahanmu

Percayalah, pilihan-Nya adalah yang terbaik untukmu

Aku hanyalah pelengkap yang akan menyempurnakan keimananmu

Aku bukanlah orang hebat seperti kata mereka

Tapi, jika DIA memilih diri ini sebagai pendampingmu

Aku pasti siap,

Semoga hatimu terjaga selalu

Dariku untukmu yang selalu menjaga diri untukku 


\section{Kamu (Seseorang)}

Kamu,

Adalah seseorang yang membangkitkanku Walaupun rintangan selalu menghadangku

Kamu, selalu hadir memberikan motivasimu

Kamu,

Adalah seseorang yang mencintaiku

Walaupun banyak yang mencintaiku

Kamu, selalu mencintaiku sepenuh hatimu

Kamu,

Adalah seseorang yang menyadarkanku

Walaupun buruk sekali tingkah lakuku

Kamu, selalu tabah menghadapi kelakuanku

Kamu,

Adalah seseorang yang setia mendengar ceritaku

Walaupun tak pernah usai tulisan usangku

Kamu, selalu menikmati tanpa beban di pundakmu

Dan Kamu,

Adalah seseorang yang membawaku kepada-Nya

Walaupun sering lalai dengan indahnya dunia Kamu, selalu mengingatkan akan semua nikmat-Nya

Kamu, aku berharap itu kamu

lya, kamu yang akan menjadi ibu dari malaikat kecilku

Dan menjadi pelengkap dalam kehidupanku 


\section{Karena DIA Sebaik-baiknya}

Allah adalah dzat yang abadi

Tak ada yang mampu menandingi

Allah adalah dzat yang selalu menepati janji

Tak seperti makhluk-Nya yang selalu mengingkari

Mencoba untuk tetap kuat

Tetap kuat menghadapi ujian

Berusaha untuk selalu taat

Taat demi sebuah kebahagiaan

Allah adalah dzat yang maha pengasih

DIA selalu ikhlas memberikan kasih

Allah adalah dzat yang maha penyayang

DIA tak pernah memilih siapa yang ingin disayang

Karena Allah sebaik-baiknya

Dan hanya Allah satu-satunya

Jika kamu masih berfikir Allah tak adil

Aku rasa kamu masih dalam kondisi labil

Karena Allah sebaik-baiknya

Dan hanya Allah yang bisa

Jika kamu berlebih mencintai makhluk-Nya

Aku rasa kamu harus belajar makna cinta sebenarnya

DIA pengasih, DIA penyayang

Dan DIA-lah yang paling sempurna

Aku harap kamu selalu mencintai-Nya 


\section{Karya Ataukah Sampah}

Sejenak aku coba buat sebuah sajak Untuk meyakinkan diri bahwa jaman sudah berubah

Tapi apa dayaku, selalu saja karyaku diinjak Mereka menganggap semua karyaku layaknya sampah

Ketika dibuang baunya menjalar kemana-mana

Dan mereka mulai mempersoalkan hal itu Padahal mereka sendiri yang membuangnya

Tapi mereka tak pernah sadar akan hal itu

Karya yang aku buat memang tak sebagus para penyair Karena, aku lebih senang menikmati waktu yang bergulir

Hehe, aku tahu itu bukanlah hal penting bagi mereka Tapi salahkah jika karya ini aku jadikan sarana Bukan memaksa untuk mengerti

Tapi sedikit memaksa untuk kembali

Kembali kejalan-Nya yang sudah pasti

Yang akan membuat mereka lebih berinovasi

Berinovasi dalam hal yang positif Bukan hal yang berujung negatif

Ingatlah kamu itu pandai Jadi, tetaplah berlaku pandai

Stop berlaku bodoh Kalau dirimu itu tidak bodoh Bodoh dalam hal kelakuan Bahkan dalam hal kesopanan 
Maka jadilah orang yang pandai dalam segala hal

Aku tak meminta pujian apapun atas karyaku Bahkan karyaku bisa menjadi sampah jika kamu mau Aku tak meminta dianggap hebat atas karyaku Karena dengan menghargai itu sudah cukup bagiku

Aku membuat ini bukan karena aku benci padamu Aku membuat ini bukan karena aku iri hati padamu Lebih baik aku menyadarkanmu dengan Tamparan Sebelum DIA yang mengingatkanmu dengan Teguran

Hargai karya orang lain dan jangan coba mengkritik Hargai perbuatan orang lain dan jagalah selalu kode etik Aku hanya berusaha menegur dengan tamparan kecil melalui karyaku

Semoga ini, bisa mengingatkanmu akan diri-Nya bukan diriku 


\title{
Arti Sebuah Kebahagian
}

Kebahagiaanku adalah kebahagiaan-Nya juga

Jika memang aku bahagia dan DIA tidak

Apa gunanya aku hidup didunia milik-Nya?

Hanya menghabiskan waktu untuk bertindak

\author{
Milikku adalah milik-Nya \\ Jika DIA mengambilnya \\ Aku harus bisa mengikhlaskan \\ Dan aku harus bisa merelakan
}

Kita diciptakan untuk beribadah kepada-Nya Jika dengan-Nya saja kita selalu menghiraukan

Tak ada gunanya kita bahagia didunia milik-Nya Karena dunia takkan mampu memberi kebahagiaan

Kehidupan masa depan yakni akhirat Dan kebahagiaanku sempurna jika berhasil taat

Akhirat yang menjadi kehidupan terakhir Dan taat sampai dunia benar-benar berakhir

Sudah banyak sajak tentangnya Kelak akan aku buat sajak tentang-Nya DIA yang membuat aku selalu bahagia Dan kebahagiaan itu tak ada batas jika selalu bersama-Nya

Terima kasih, ENGKAU selalu memberiku kemudahan untuk mencapai semua kebahagiaanku

Semua hanya untuk-Mu tak ada yang lain selain diri-Mu 


\section{Kebersamaan}

Bersamamu adalah bukti hidup itu berdampingan Mengapa kamu tak duduk sejenak ceritakan kenangan?

Hujan turun begitu deras meluapkan emosinya Seharusnya kamu tahu saat aku rindu duduk bersama

Kebersamaan yang aku nikmati tak hanya denganmu

Tapi kebersamaan bersama keluargaku

Kebersamaan saat bersama temanku

Dan bersama orang yang penting dalam hidupku

Banyak cerita yang aku dapatkan

Saat aku memutuskan untuk duduk bersama

Tak hanya darimu aku dapatkan pengalaman

Tetapi saat bersama siapa saja aku bercerita

Waktu berjalan begitu pelan

Dan kusadari semua telah terjadi

Mencoba menahan beratnya beban

Lalui semua dengan motivasi diri

Semua berlalu begitu cepat

Dahulu aku hanyalah pendengar setia

Tapi sekarang aku pembicara yang hebat

Dengan cerita klasik yang bisa menghibur semua

Dari kalian semua, aku belajar Akan arti dari kebersamaan

Dari kalian semua, aku ikhtiar Akan do'a yang aku panjatkan 
Lagu yang ku dengar takkan berarti

Jika aku tak memahami liriknya

Tulisan yang ku buat takkan di mengerti

Jika aku tak memaknai setiap kalimatnya

Aku rindu saat pertama, bertemu dengan kalian Kalian menyambutku dengan penuh kehangatan Aku rindu saat bersama, bercerita demi hiburan Kalian membuat cerita demi sebuah candaan

Terima kasih atas kebersamaan

Yang kalian beri kepadaku Itu semua takkan terbalaskan Walau sampai habis waktuku

Semoga DIA selalu melindungi kalian semua

Semoga DIA selalu mengampuni kalian semua Dan semoga kita takkan terputuskan sampai akhir usia 


\section{Keindahanmu}

Aku berjalan menuju jalan utama

Tak ku sangka bulan menyambutku

Padahal matahari sudah ingin menyapa

Tapi kurasa, bulan belum puas menemaniku

Keindahanmu tak terkira dan tak bisa aku gambarkan

Bagai sebuah melodi yang selalu berirama

Dirimu begitu indah, dan membuatku terus memikirkan

Terlintas dibenakku untuk bisa bersama

Tersenyumku melihat dirimu

Tapi, sekedar kagum saja denganmu

Ada niat untuk membangun hubungan

Tapi aku rasa, diriku belum bisa meyakinkan

Entahlah ini hanyalah perasaan saja

Untuk apa aku terus-terus memaksanya

Cukup berdiri tegap dan terus menatap tujuan

Aku takkan bisa maju jika terus membawa perasaan

Berbicara BAPER, diriku sering sekali melakukan Aku BAPER bukan untuk menghabiskan waktu dengan itu

Tapi dengan BAPER, aku bisa mengekspresikan Bilamana tak tersampaikan, itu bisa menjadi sebuah pelajaran buatku

Memang keindahannya tak tergambarkan Bukan berarti semua itu untuk dinikmati Melainkan kita harus terus menjaganya Dengan ketulusan dan cara yang semestinya 


\section{Kekuatan Cinta}

Percaya atau tidak kamu pasti tidak sadar

Alam bawah sadarmu mengatakan

Perasaan yang terus menerus menjalar

Hingga menjadi sebuah ungkapan

Ungkapan yang saling terkait

Terkait antara satu dengan yang lain

Sangat rentan membuat hati menjadi sakit

Karena permainan yang saling membuat yakin

Tak pernah terbayangkan sebelumnya Terbayang karena slalu saja menjadi kenangan

Sekarang aku dan kamu sedikit membuka Walau dahulu pernah aku dan kamu berbagi perasaan

Kekuatan CINTA yang sebenarnya Adalah CINTA dari Sang Pencipta Tanpa ada yang dibuat kecewa Dan tak ada yang dibuat tersiksa

Kita memberikan CINTA secara berlebihan Itu akan menjadikan tak baik buat kehidupan kita DIA memberikan CINTA secara berlebihan Akan tetapi kita tak sadar akan kehadiran-Nya

Wallahi, aku menyakini kekuatan CINTA Dan aku yakin jika aku mencintai-Nya, DIA akan mencintaiku juga 


\section{Kenapa Dirimu Tak Bahagia}

Seperti kata mereka bahagia itu sederhana

Memang sederhana jika kita menikmatinya Lantas apa yang kita pikirkan tentang bahagia? Kenapa kita tak bahagia dengan kehidupan dunia?

DIA menciptakan rasa syukur untuk kita nikmati Terkadang kita saja yang kurang dalam mensyukuri

DIA memberikan apa saja yang kita ingini Hanya saja kita selalu memburu demi nafsu duniawi

Dirimu tak bahagia sebab dirimu tak merasa bahagia Dirimu tak mengerti apa makna bahagia sebenarnya Lapangnya dada adalah cara kita mensyukurinya Lepaskan semua yang seharusnya bukan wilayah kita

Ada batasan di mana itu wilayah kita Dan batasan di mana itu adalah wilayah-Nya Seharusnya bahagia itu tak ada yang menyiksa Hanya saja kita mencari dengan jalan terpaksa

DIA memberikan nikmat iman DIA memberikan nikmat hidup Itu adalah jalan kebahagian Jangan buat dirimu jadi tertutup

Jika kamu bersyukur kata Allah, niscaya Allah akan menambahkan nikmat kepadamu 
Mereka selalu ada buatku Membuat lembaran baru dalam kehidupanku

\section{Mereka selalu ada waktu}

Menemani menghabiskan waktu bersamaku

Terima kasih untukmu, sudah menjadi bagian dalam hidupku

\section{Dan Pada-Nya aku berdoa}

"Jagalah mereka selalu di manapun mereka berada karena mereka adalah keluargaku"

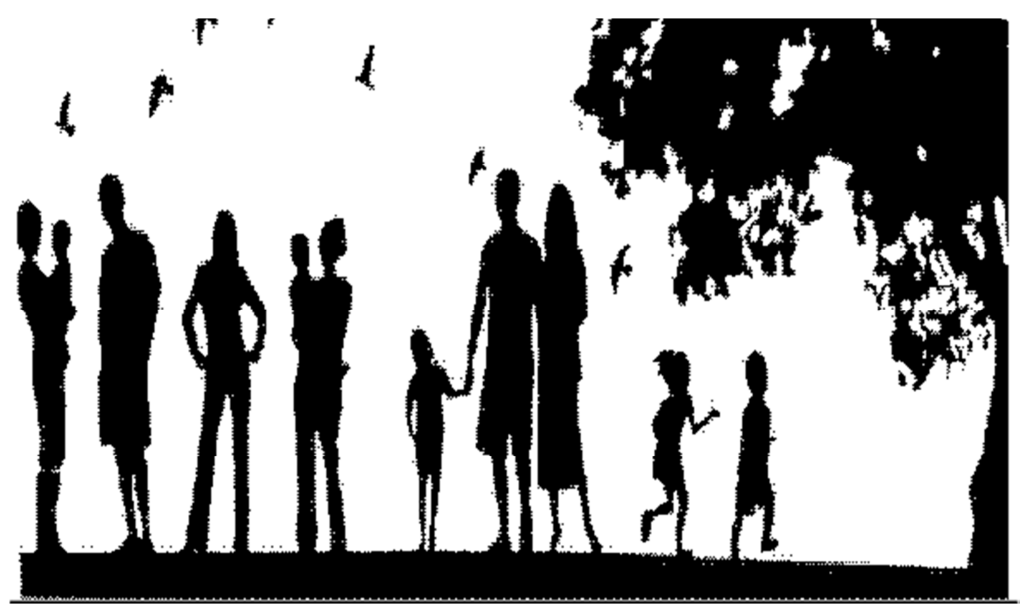




\title{
Kau Harus Tahu
}

Keinginan diriku takkan kau tahu

Keinginan hatiku takkan kau pahami

Jika kau selalu menimbulkan pilu Aku yakin kau takkan mudah mengerti

\author{
Kau harus tahu \\ Diriku adalah diriku \\ Jangan kau ubah sesuai keinginanmu \\ Karena aku tahu, apa yang baik untukku
}

Orang lain datang dikehidupanku Karena itu sudah tepat disuatu waktu Allah mendatangkan aku dan kamu Untuk saling berbagi mengisi waktu

Kau harus tahu

Sesuatu hal yang kamu tak tahu Kamu harus paham

Semua itu memiliki makna yang dalam

Aku menyampaikan satu

Belum tentu kamu mengerti itu

Aku menyampaikan dua

Belum tentu kamu percaya

Percayalah, Allah tahu semua itu

Aku tentu tak bisa memaksamu Karena kamu pasti punya tujuan tertentu

Yang tak pernah aku tahu apa itu 


\section{Kepercayaan Dirimu}

Yakinkan dirimu bahwa kau mampu Janganlah putus asa dengan keputusanmu

Yakinkan dirimu bahwa kau kuat Nikmati semua, jangan ada yang terlewat

Terkadang sering kali keraguan muncul Dan menurutku itu sangat mengganggu Bergeraklah cepat seperti macan tutul Tak banyak diam dan terus menunggu

Yakinkan mereka bahwa itu adalah pilihanmu Pilihan yang akan menjadi batu loncatan buatmu Yakinkan mereka yang selalu mengasingkanmu Mengasingkanmu karena kau selalu saja ragu

Menerima tantangan yang baru Itu sangat berguna buat dirimu Semakin kau latih keyakinan dalam dirimu Semakin sanggup kau mengendalikan dirimu

Adalah kekuatan dalam diri

Yakni kepercayaan itu sendiri

Ditambah dorongan dari orang sekitarmu Lengkap sudah semangat yang hadir untukmu

Kepercayaan diri memang utama Tapi padukan semua dengan yakin juga kepada-Nya Sebab DIA yang selalu berperan dalam kehidupanmu 


\section{Kita}

Kita adalah perpaduan antara aku dan kamu Karena DIA yang membuat aku dan kamu menyatu

Kita adalah anugerah terbesar dari-Nya Dan karena itu juga bagian kasih dan cinta-Nya

Kita menyatu dalam satu masa depan

Kita melangkah dalam satu tujuan

Tanpa-Nya semua takkan bisa berjalan

Dan tanpa-Nya semua takkan bisa terselesaikan

Lewat do'a aku sampaikan

Agar aku bisa mendapatkan

Sampaikan semua keinginan

Mendapatkan semua kebahagiaan

Yang menjadikan Kita adalah DIA

Sebab DIA ingin aku dan kamu bersama

Jika nanti, aku tak bisa bersama

Cukup syukuri saja apa yang ada

Karena dengan mensyukuri kita merasa bahagia Dan bahagia yang sebenarnya adalah saat bersama-Nya DIA memberikan apa yang kita inginkan Maka bersyukurlah demi kebahagiaan

Aku harap kita saling mendo'akan Agar apa yang kita inginkan dapat tersampaikan Berdo'a dengan penuh kesabaran dan keikhlasan Agar apa yang kita harapkan dapat tercapaikan 


\section{Kita Harus Tuli}

Terkadang telinga kita memaksa untuk mendengar

Terkadang bibir kita berucap untuk berkomentar

Ada satu hal yang tak perlu kita tanggapi

Ada banyak hal yang perlu kita klarifikasi

Terkadang tuli dibutuhkan untuk membatasi dilema Dilema yang dibuat dengan sengaja agar hati bisa gembira Terkadang tuli dibutuhkan untuk menguatkan keyakinan Keyakinan yang sering patah ketika berada ditengah jalan

Kita tak harus mendengar komentar orang Karena komentar mereka hanya sebatas perkataan

Kita harus tuli dengan semua komentar orang Yang selalu menganggu dan merusak keadaan

Terkadang kita memang harus mengabaikan Mengabaikan semua perkataan orang lain Karena mereka selalu asik membandingkan Membandingan antara satu dengan yang lain

Ada komentar yang bermanfaat dan ada juga yang tidak Jadi manfaatkanlah komentar itu sebaik mungkin Jangan memvonis, cukup lakukan dan lekas bertindak Jadilah dirimu sendiri dan jangan menjadi orang lain

Allah menciptakan lisan untuk berkata yang baik Allah menciptakan telinga untuk mendengar yang baik Kita harus tuli ketika orang berbicara hal yang tidak baik Karena itu bisa membuat diri kita menjadi tak baik 


\title{
Kita Yang Berbeda
}

Tak pernah aku bayangkan secepat ini Yang aku takutkan benar, terjadi adanya Perbedaan yang mengalahkan rasa ini

Dan kita menyerah kalah, pada segalanya

\author{
Kamu memutuskan untuk pergi \\ Melepaskan segala cerita \\ Menghilang disaat datangnya pagi \\ Dan hadir, ketika tiba senja
}

Pekat malam jangan membuat resah Hadapilah ini sebagai pelajaran hidup Masih saja kamu menganggap ini susah Memaksa melihat dengan mata tertutup

Tuhan kita hanya Satu

Berbeda pendapat adalah biasa

Mungkin memang tak bisa menyatu

Biarlah rasa ini menua hingga akhir usia

Perbedaan yang memisahkan kita

Mungkin DIA tak inginkan aku dan kamu bersama

Biarlah, cukup aku pasrahkan semuanya

Walau kita berbeda, aku tahu perasaan itu tetap sama

Kita saja yang berbeda

Mungkin karena kita tak mau saling menerima

Menerima semua yang telah diberikan oleh-Nya 


\section{Ku Cinta Kau, Kau Cinta Dia}

Sungguh berat ku rasa

Beban pikiran saat ini

Entah mengapa aku memaksa

Mungkin ini hanya masalah hati

Sebagai mana pemandangan yang ku lihat

Selalu saja ada objek yang menghalangiku Aku hanya bisa diam dan hanya bisa mengumpat

Mungkin kelak kamu akan mengerti diriku

Aku tak peduli kamu bersamanya Aku tak peduli kau menghabiskan waktu dengannya

Yang aku takut, praduga dari mereka Yang akan membuatmu kelak menyesalkannya

Bukannya aku takut akan kehilangan dirimu

Tapi aku tak ingin melihatmu terluka Mungkin saja saat itu kamu tak melihatku

Karena kamu tak pernah merasa peka

Ini hanyalah bualan saja, Jangan kamu anggap aku serius

Ini hanyalah perasaan saja, Jangan kamu anggap aku tak tulus

Waktu berjalan begitu pelan

Bagai roda yang terus berputar

Kamu pun berlalu meninggalkan beban

Perlahan rasaku ini akan memudar 
Berharap kamu tak salah memilihnya Dan aku harap tak ada kecewa di akhir cerita

Karena aku tahu kamu mengenangnya Anggap saja aku dan kamu pernah menjadi kita

\author{
Mencintaimu adalah hal terindah \\ Yang pernah aku rasa dalam kehidupan \\ Dirimu adalah sebuah anugerah \\ Dari-Nya yang takkan terlupakan
}

\author{
Aku mencintaimu \\ Dan kamu mencintainya \\ Itu bukan masalah bagiku \\ Selama kamu bahagia dengannya
}

Cerita Indah Namun Tiada Arti

Mungkin nanti kamu akan segera mengerti

Harapanku, jagalah selalu hatimu

Abaikan saja hati yang lewat dihadapanmu

Karena untuk saat ini, belum saatnya untuk itu

Maaf aku telah menitipkan rasa secara diam

Cukup aku simpan perasaan ini dalam-dalam 


\title{
Kuasai Dirimu
}

Sebagai salah satu makhluk

Dirimu adalah ciptaan-Nya yang sempurna

Jangan lemah apalagi takluk

Sebab dirimu telah diberi pilihan oleh-Nya

\author{
Sebagai seorang hamba \\ Dirimu adalah salah satu cinta-Nya \\ Jangan rapuh apalagi putus asa \\ Sebab dirimu telah diberi kekuatan oleh-Nya
}

Sebagai seorang yang penuh dengan nafsu Dirimu bisa lebih rendah dari mereka yang tak berakal

Jangan hilang akal apalagi tak punya malu Sebab dirimu telah diberi oleh-Nya cinta yang kekal

Jika dirimu tak bisa mengatasi dirimu

Dirimu akan terbawa suasana dan hanyut

Layaknya bunga yang sedang layu

Nikmati proses boleh saja, asal jangan larut

Kuasai dirimu

Sebagaimana DIA menjagamu selalu

Kuasai dirimu

Sebagaimana DIA memberimu ilmu

Tak ada manusia yang luput dari dosa

Tak ada manusia yang lepas dari dunia

Jadi bawalah DIA disetiap langkahmu, untuk membantumu berjalan di dalam gelapnya lorong kehidupan dunia 


\section{LAA ILAAHA ILLALLAH}

Saat itu aku sedang mendapatkan musibah

Di mana seorang yang aku cintai pergi meninggalkan

Saat itu aku merasakan yang namanya gundah

Di mana diriku benar terombang ambing oleh perasaan

DIA membantuku bangkit melalui ayat-Nya Entah kegundahan itu hilang seketika

Seperti angin yang datang lalu pergi begitu saja Seperti perasaan yang dititipkan namun hilang dan sirna

Tidak ada Tuhan selain ALLAH

Kalimat tauhid yang menjadi kekuatan sebuah kisah

Jika aku sombong dengan semua ini

Lantas apa tujuan DIA menciptakan ini?

DIA menciptakan ini hanya untuk beribadah Aku tak pantas membanggakan semua yang dititipkan Jika aku bersikap di dunia seolah terserah Apa dunia ini akan ku bawa di hari kemudian?

Tidak Ada Tuhan Selain Allah Karena hanya DIA yang berkehendak atas semua Sekalipun dunia ini aku kuasai sepenuhnya Itu takkan menurunkan sedikit kekuasaan-Nya

DIA menciptakan malaikat, jin dan manusia Dan DIA juga yang akan mengambil semua "Inna lillahi wa inna ilaihi raji'un"

(2:156) 


\section{Lakukan Sesuai Keinginan Hatimu}

Dahulu, kamu pernah melakukan hal seenaknya Tanpa berfikir apakah orang lain menyukaimu atau tidak Dahulu, kamu pernah melakukan hal diluar logika Tanpa berfikir apakah orang lain nyaman atau tidak

Kembali kamu disadarkan oleh perkataan mereka Sakit sih, tapi kamu pasti tahu itu demi kebaikanmu

Perkataannya bukan untuk membuatmu terluka Tetapi membuat lebih baik kehidupan di masa depanmu

Terkadang kamu melakukan tanpa memikirkan hatimu Terkadang kamu melakukan tindakan diluar logikamu Ayahku pernah berkata, Lakukan saja keinginan hatimu Walau berat, aku yakin kamu bisa mengerti hatimu

Sebelumnya, aku ucapkan terima kasih kepadamu Kamu sudah selalu setia dalam mengingatkanku Walau sebenarnya aku selalu menghiraukanmu Aku janji kepadamu, akan aku lakukan semua itu

Lakukan saja, keinginan hatimu, jika baik itu akan berbuah baik, jika keluarannya buruk maka tinggalkanlah Aku, kamu, dan mereka, ada atas keinginan-Nya Terimalah, itu semua sudah diatur oleh-Nya

Lakukan saja keinginan hatimu Jika ragu mundurlah selangkah dan majulah 2 langkah Sebab dirimu tahu mana yang baik untuk dirimu sendiri 


\title{
L.D.R
}

Jarak yang menjadi masalah di sini Jujur saja, banyak yang tak mampu

Setia yang selalu memaksa diri Percayalah, itu semua hanyalah palsu

Semua bermula dari tatap matamu Yang membuat aku membuka hatiku

Bukan memaksa untuk mencintai

Tapi beginilah, tak bisa aku pungkiri

\author{
L.D.R itu \\ Long Distance Relationship \\ Itu kata mereka yang mencoba bertahan di balik kepalsuan \\ Itu kata mereka yang mencoba memaksa demi kekecewaan
}

Singkat cerita aku berjalan meninggalkan Meninggalkan semua yang selalu hadir di dalam angan Apa yang aku pikirkan selalu saja berubah Apa diriku ini harus benar-benar berbenah?

Jaminan kesetiaan takkan mudah aku dapatkan Jika aku sendiri tak pernah berusaha mendekatkan Yang aku tahu DIA yang selalu setia denganku Setia dalam menemani dan membimbingku

Aku tak keberatan jika kamu harus ku tinggalkan Maafkan jika hubungan berjarak ini hanya bualan Aku tak bermaksud untuk menyakitimu Hanya saja aku dibutakan oleh nafsuku 
Mencintaimu adalah menenangkan Tapi aku tak ingin kebahagiaan itu hanya sementara

Kesetianmu sungguh menyakinkan Tapi aku tak ingin yakinmu lebih daripada-Nya

\author{
Akhirilah hubungan jarak jauh ini \\ Aku tak ingin, kita saling menyakiti \\ Percayalah, jika memang ditakdirkan \\ DIA akan memberikan dengan kemudahan
}




\title{
Lucunya Negeriku
}

Ributnya politikus membuatku pening Pening dengan segala statement dan perkataan

Tertawa hanya karena permainan intuisi Keadaan bodoh dibuat demi membuat rakyat berselisih

Kepintaran yang diadu karena merasa diri hebat Kebodohan yang muncul karena adanya kompetesi debat Membuat kebodohan semakin terlihat dibalik kepintaran

Dan membuat semakin menginjak kesengsaraan

Kita tertinggal jenjang pendidikan yang sangat jauh Karena yang pintar berbicara, yang akan berkuasa

Tarik ulur yang tiada habisnya karena kekuasaan

Membuat mereka buta melihat keadaan

Kurangnya kepekaan karena tak pernah merasakan Selalu menyalahkan padahal semua sudah di jelaskan

\author{
I pray for everyone \\ Begitulah politik kita, \\ Ribut tapi tak ada penyelesaian \\ Hanya bertikai demi seorang pemenang
}

Welcome to Indonesia

Di mana orang benar diinjak, dan orang salah disanjung

Di mana orang benar dibiarkan, dan orang salah di utamakan

Seandainya mereka yang bermain kotor mempunyai hati Aku yakin mereka takkan melakukan hal bodoh seperti ini 


\section{Luka}

Aku melihat luka dibalik senyummu Tapi kamu tak pernah mengakuinya Aku tak bisa melihat kamu seperti itu Jadi katakan jika kamu ingin bercerita

Ada cerita di dalam rasa

Kamu bisa menceritakan semua kepadaku

Sehingga kamu bisa kembali merasa Semua yang nyata telah mewarnai harimu

Mungkin, kamu tak bisa lupakan dirinya Mungkin, aku tak mampu mengganti hadirnya Namun aku bisa buat kamu rasa Semua yang ada didepanmu

Biarkanlah diriku, Bersamamu selalu Berikanlah senyummu, Dan hapuskan sedihmu

Sebenarnya luka itu memang tak berdarah Tapi dengan itu kamu sangat dibuat patah Aku bisa mendengar apa saja ceritamu Tapi kamu tahu, aku tak selamanya untukmu

Bersabarlah, lukamu akan segera hilang bersama waktu

Selama DIA, kamu jadikan tempat bergantungmu

Mungkin sembuhnya luka itu butuh waktu

Tapi percayalah, lukamu itu adalah salah satu cara-Nya untuk menguji dirimu Jadi, kuatkanlah dirimu selalu 


\title{
Maafkan Aku
}

Aku yang bersalah dalam cerita ini Aku terlalu membuatmu mencinta

Maafkan aku, jika memaksa hati Membuat kecewa dan membuat dilema

Aku tahu dirimu yang paling setia Aku tahu dirimu yang paling berkorban Maafkan aku, jika rasamu menjadi sia-sia Membuat keputusan yang sangat menyakitkan

Mungkin panah yang aku tancapkan terlalu dalam Sehingga dirimu sulit melepaskan dengan kerelaan

Maafkan aku, jika kisahmu menjadi kelam Membuat sayatan sehingga kamu pun kesakitan

Dirimu sangat menginspirasiku

Kisah cinta ini menurutku indah

Maafkan aku, jika aku merusak ceritamu

Dengan membuat abstrak sehingga membuatmu resah

\author{
Aku hanya berharap \\ Kamu memaafkan aku \\ Aku berjanji takkan membuatnya gelap \\ Agar kedepannya aku bisa memperbaiki diriku \\ Jika DIA saja mampu memaafkan, maka maafkan aku \\ Walau janjiku belum bisa dipastikan \\ Aku akan berusaha memperbaiki demi kepastian
}




\section{Manusia dan Alam}

Aku pernah diberi tahu ayahku Bahwa alam pun sama denganku Sama-sama makhluk ciptaan-Nya Dan sama-sama harus dijaga

Terkadang kita lupa memberi makan tubuh kita Sehingga kitapun mudah melupakan-Nya Alam yang kita tempati pun lupa kita jaga Dan mengabaikannya hancur begitu saja

Allah menciptakan alam sebagai penyeimbang kehidupan

Bukan malah dirusak demi sebuah keuntungan Allah menciptakan alam sebagai pelengkap kehidupan Seharusnya kita menjaga bukan malah mengabaikan

Setelah pertemuanku dengan aktivis alam

Semua jadi terbuka lebar siapa yang salah Walau harapan mereka selalu saja tenggelam Setidaknya mereka berusaha untuk mengubah

Diri kita sendiri yang selalu lupa Merasa makhluk yang paling sempurna Kita lupa bahwa Alam juga perlu kita Agar kehidupan selalu berjalan seirama

Ya Allah ampuni kami Yang selalu merusak ciptaan-Mu Dan merusak semua tatanan-Mu 


\section{Masa Lalu}

Masa lalu adalah masa di mana ada kenangan di sana Setiap orang memiliki masa lalu yang berbeda pastinya

Termasuk aku sebagai penikmat kenangan

Tapi sangat mudah untuk ku lupakan

Suramnya masa lalu terkadang membuat jenuh

Jenuh menjadikanku semakin berkeluh

Keruhnya masa lalu semua karena berisi dosa

Membuatku tak yakin bisa menuju syurga

Adalah diriku yang terlalu bajingan di masa lalu Merusak semua tanpa harus berfikir dahulu

Maafkan diriku yang telah lalu Karena selalu dibutakan nafsu

Berkali-kali aku mengingatkan mereka Agar kisah masa laluku tak terulang lagi Tapi selalu saja mereka tak mau percaya Dengan cinta palsu yang selalu tak pasti

Aku bingung mereka pun sering mencaciku

Dengan sumber dari kisah di masa laluku Apa dengan itu mereka bisa menjatuhkanku?

Tentu tidak, semua tergantung dari prinsipku

Seberapa kuat dirimu menginjakku

Dengan kisah di masa laluku, silahkan lakukan saja Ketika kamu lelah menginjakku, jangan lupa beritahu aku 


\section{Masa Lalu Ku}

Mungkin masa lalu ku begitu suram

Mungkin juga masa lalu ku begitu kelam Jika ingin menjatuhkan dengan kisah dimasa lalu ku

Silahkan lakukan dengan sekuat tenaga milikmu

Aku menjadikan masa lalu sebagai temanku

Tak ada manusia yang tak memiliki itu

Setiap masa lalu akan memiliki pelajaran

Yang sangat berguna dalam kehidupan

Berteman dengan masa lalu

Menjadikan diriku semakin dewasa

Karena apa yang telah lalu

Membuatku semakin kuat menghadapi dunia

Move On dari masa lalu memang sulit

Tapi aku tak ingin ini menjadi penyakit

DIA yang membantuku untuk bergerak

Agar aku tidak sembarang dalam bertindak

Mungkin kamu bisa menutupi masa lalumu Tapi masa lalu itu takkan mudah terlupakan olehmu Jadikan masa lalumu sebagai batu loncatan Agar kelak, kamu mudah menjalani kehidupan

Anggap saja sajak ini saling berhubungan Jika kamu masih saja membayangkan Habislah waktumu hanya karena memikirkan 


\section{Masih Ada Senyummu}

Aku sengaja duduk di tempat di mana aku biasa duduk

Terlihat raut wajahmu seperti bunga yang layu Aku hanya bisa terdiam dan hanya bisa menebak Aku tak tahu, apa yang terjadi pada dirimu

Berharap senyummu kamu lemparkan kepadaku

Tapi nihil, karena sedang tak baik kondisimu

Sepertinya kamu sedang merasakan sedih yang berarti Entah laki-laki mana yang berani membuatmu tersakiti

Aku mencoba membangkitkan semangatmu Dengan candaan murahan yang menjadi senjataku Dan akhirnya kamu pun tersenyum dengan lepas Begitu yang aku rasakan saat sedihmu mulai terbebas

Bahagia yang tak terbatas yakni

Saat aku bisa bersamamu menghabiskan waktu

Walau itu hanyalah khayalan di hati

Tak menutup kemungkinan kamu akan memilihku

Ekspresi yang aku tunggu dari raut wajahmu Yang menambah semangatku untuk terus berjuang Senyummu saja mampu menggetarkan hatiku Menambah semangat dikehidupan yang akan datang

Senyummu membuatku sulit untuk tidur Aku takkan bisa lepas dan mudah untuk kabur Senyummu selalu menghantui tidurku

Dan selalu datang disaat aku membutuhkanmu 
Walau tatapan sinismu selalu membuatku takut

Tapi aku tahu, bukan itu maksudmu

Dengan hati dan perasaan yang sangat lembut

Kamu selalu mengalihkan duniaku

Berharap DIA menjagamu selalu

Berharap DIA mempertemukanmu dengan sebagian

dari dirimu

Dan berharap DIA selalu bersamamu, menemanimu disaat sedih melanda hatimu 


\section{Diriku adalah Diriku Hanya diriku dan DIA yang mengetahuinya}

Kepercayaan diri menjadi faktor utama untukku

Dan masa lalu adalah kenangan terindah buatku

Banyak pembelajaran dari mereka yang aku dapatkan Akan aku terapkan sebaik mungkin di dalam kehidupan Jadi, Cukup do'akan saja diriku

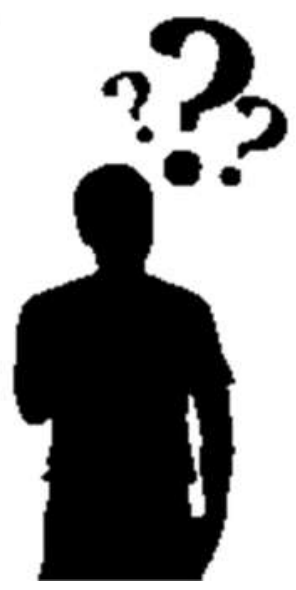




\section{Melampaui Batas}

Malaikat adalah makhluk yang selalu patuh pada-Nya

Jin adalah makhluk yang ingkar atas nikmat-Nya Manusia adalah makhluk yang selalu dicintai oleh-Nya Bagaimana bisa DIA dikatakan tidak adil atas semua?

DIA menciptakan semuanya berangsur-angsur

Atas dasar cinta Nur kekasih-Nya DIA tidak mungkin menciptakan sesuatu dengan ngawur Karena DIA memiliki tujuan atas semua ciptaan-Nya

Kita sebagai golongan Manusia Masih saja sombong atas yang dimiliki

Malaikat saja tidak pernah membantah-Nya Kenapa kita selalu mengabaikan perintah yang diberi?

Merasa memiliki dunia Sudah lupa untuk mengingat-Nya Melakukan sesuatu melewati batasnya Manusia akan terus hina jika tak memiliki taqwa

Iman sebagai pembatas Agar kita tidak melampaui batas

Manusia diberi pilihan itu sudah tentu Lakukan apa saja selagi kamu tak punya malu

DIA menghadirkan kita untuk taat kepada-Nya Bukan malah mengingkari semua yang diberi oleh-Nya Jangan melampaui batas, jika kamu ingin balasan dari-Nya 


\section{Melepaskanmu}

Melepaskanmu bukan karena aku tak mencintaimu

Melepaskanmu bukan berarti aku membencimu

Aku melepaskanmu karena aku ingin menghargaimu

Aku melepaskanmu karena aku takut menyakitimu

Aku mencintaimu dengan segenap rasaku

Rasa yang ku berikan sepenuhnya kepadamu

Tapi aku tak ingin ini, menjadi dosa untukmu

Maafkan aku, karena harus melepaskanmu

Tenanglah dan jaga dirimu di sana

Yakinkan dirimu selalu kepada-Nya

Kamu pasti tahu maksud dan tujuanku

Aku hanya tak ingin kamu terluka karenaku

Melepaskanmu dengan penuh kerelaan

Dengan jalan agar ini bisa diikhlaskan

Belajar dewasa dari sebuah perpisahan

Semoga kita selalu berada di dalam lindungan

Aku tak memaksa, jika dirimu membenciku

Itu adalah hak yang menjadi pilihanmu Jika dengan membenciku kamu bisa melupakanku

Silahkan lupakan dan kenang selalu aku

Mungkin kamu bisa kapan saja melupakanku

Tak apa, asal jangan kamu lupakan Tuhanku

Karena DIA telah membahagiakan hidupku dan hidupmu 


\section{Melupakanmu \\ (Butuh Proses)}

Melupakanmu bukanlah hal yang mudah buatku

Menurutku butuh proses yang cukup lama

Tak mudah karena aku selalu mengenangmu Butuh proses karena aku selalu membuat kecewa

Aku telah salah mencintai

Seharusnya DIA yang aku yakini

Bukan dirimu yang pasti akan meninggalkan

Bukan juga dirimu yang pasti akan mengecewakan

Di dalam cerita ini aku yang bersalah

Memaksa hati untuk saling mencinta Jujur saja untuk menyakiti aku tak pernah Karena aku dilahirkan oleh seorang wanita

Aku akan melupakanmu nanti

Maaf jika itu butuh proses yang lama

Aku akan berusaha tidak mengulangi lagi

Dan akan berusaha tidak lagi membuat dilema

Melupakanmu memang menyakitkan

DIA membuatku sadar akan kesalahanku

Tapi, dengan itu akan aku jadikan pelajaran Dan DIA adalah harapan baru dalam kehidupanku

Aku hanya bisa berharap DIA selalu menjagamu di sana 


\section{Mencintai Dalam Diam}

Aku pernah ditanya seseorang

Seberapa besar cintaku kepadanya

Kita bercerita hingga senja datang Dan jawabanku "cintaku sebesar cintanya"

Aku tak ingin melebihkan cintaku kepadanya Karena aku takut membuat DIA menjadi kecewa

Maka cintaku sama seperti cintanya

Dan DIA adalah komponen utama

Mencintai dalam diam

Banyak yang berkata itu menyenangkan

Walau sering sekali tenggelam

Jujur saja aku merasakan kebahagiaan

Siapa yang tahu keputusan-Nya

Dengan siapa dan bersama siapa

Itu merupakan sebuah rahasia

Dan hanya DIA yang mengetahuinya

Cinta tak butuh nekat

Tapi cinta itu butuh tekad

Walau selalu ada konflik dibalik itu

Perlahan aku pasti akan mengerti dirimu

Aku mencintai dirimu

Tapi maaf tak perlu ku sampaikan padamu Cukup DIA saja yang tahu semua rasaku ini untukmu 


\section{Mencintaimu Menenangkan}

Mencintaimu, menenangkanku Walau kamu tak berhak untuk tahu

Rasa ini akan selalu tersampaikan Lewat do'a yang selalu aku lantunkan

Merindukanmu, menyusahkanku

Karena aku harus bergerak mencarimu Walau aku bertemu dia sudah bersamamu Tegur aku, karena aku masih tetap temanmu

Biarkan saja semua itu berlalu Karena ini hanya masalah waktu Semoga saja kau bisa dapatkan bahagiamu Jika memang dia adalah salah satu pilihanmu

Aku selalu memujimu

Ketika aku bersama-Nya Tapi tak ada niat untuk bersamamu Karena DIA berkata biarkan saja

Mungkin terlalu berlebihan diriku Iya sudahlah, cukup tenang diriku Berharap DIA tak membutakan hatiku Dan semoga DIA selalu bersamaku

Aku bersyukur ada DIA dalam hidupku Dan aku bersyukur DIA menghadirkan dirimu 


\section{Menikmati Pilihan}

Kali ini pantai aku jadikan tempat pelampiasan

Cukup banyak juga waktu yang aku habiskan

"Apa sepadan dengan yang aku dapatkan?"

Sayangnya hanya hati yang bisa mengungkapkan

Rintik air hujan mulai membasahi diri

Tak marah ketika dia menghampiri

Mungkin mereka yang marah tak sadar diri

Tak pernah bersyukur, walau sebenarnya sudah diberi

Banyak momen yang aku ambil dari perjalanan ini

Perjalanan asik yang sangat menguras energi

Sebagian dari mereka kurang mensyukuri

Dari situ, maka timbulah penyakit iri

Membuat ini bukan hal yang mudah

Karena pensilku selalu saja patah

Aku tak meminta di puji atas semua karyaku

Karena menghargai, itu sudah cukup bagiku

Aku berjalan di temani rintik air hujan yang sama

Tenang kurasa jika dia berkenan untuk bersama Berharap DIA segera memudahkan dengan cara-Nya Sayangnya diri ini selalu saja memaksa untuk mencinta

Lari dari kenyataan yang mengikuti

Lari karena selalu saja di tanya soal bukti

Diri ini sulit dalam bersyukur atas semua ini Karena tak pernah mau belajar dari pengalaman diri 
Kebanyakan dari mereka lebih menyukai

Memaksa hati untuk saling mencintai

Padahal tak ada esensinya sama sekali

Hanya saja mereka beralasan butuh hiburan hati

Masih saja dari mereka terus berjuang

Bahkan apapun akan mereka berikan

Mungkin karena takut bagian dari mereka hilang

Demi perasaan tanpa logika, mereka akan bertahan

Bodoh memang, tapi apa mau di kata Sebenarnya tak ingin, semua karena terpaksa

Mereka juga takkan bisa menghindarinya

Karena sudah ada pilihan dari itu semua

Menikmatinya adalah pilihan yang sering di ambil Karena harapan yang menurut mereka itu adalah hasil

Tanpa berfikir siapa yang berhak atas semua Mereka mengabaikan, seolah tak mengetahuinya

Beri sedikit waktumu untuk-Nya

Dan janganlah sesekali kamu menjauh dari-Nya DIA akan selalu hadir di saat kamu membutuhkan-Nya Itulah kenapa, DIA adalah dzat yang akan selalu setia

Coretan-coretan ku sangat tak rapi

Menjadi sebuah abstrak yang sulit di mengerti Hanya DIA yang mampu untuk menemani Semua sudah jelas, jadi jangan banyak bertanya lagi 


\section{Menyapa Dirimu}

Pagi ini begitu dingin kurasa

Dan hujan pun hadir mengolah rasa

Ingin sekali diriku menyapamu

Sayangnya tembok itu menghalangiku

Dia, selalu membuatku tersipu malu

Tersipu dengan datarnya pembicaraan

Dia, bukan sekedar cinta buatku

Cinta yang membuatku sulit melupakan

Dicintai dirimu aku merasa sempurna

Walau aku tau ini hanya sekedar rasa

Terlalu besar cintaku kepadamu

Hingga kamu tak tau tentang rasaku

Bisa menyapamu adalah keinginanku Tapi selalu saja waktu tak berpihak padaku

Entah bagaimana cara menyapamu Mungkin sapaanku, belum pantas untukmu

Senyummu yang membuatku sulit tidur Dan bayangmu selalu saja menggangguku Ingin sekali diri ini menjadi sebuah kapur Menulis nama indahmu disudut kamarku

Tak apa diriku tak kau sapa Asal DIA jangan kau lupakan

Karena DIA selalu mengingatmu 


\section{Mereka Melupakan-Nya}

Aku tak tahu apa yang ada dipikiran mereka Mereka selalu saja mengabaikan semua perintah-Nya Aku tak tahu apakah teguran itu menyadarkan mereka Mereka selalu saja ingkar dengan semua nikmat-Nya

Apa karena kesuksesan, yang mereka ingin di dunia? Ataukah karena keinginan, hanya demi kepuasan?

Mereka buta dengan semua yang diberikan oleh-Nya Itulah faktor utama untuk melampiaskan keinginan

Setiap hari aku disuguhkan materi yang berbeda Tanpa satupun yang aku lewatkan untuk memilikinya Tapi mereka selalu saja tak pernah ingin peka Dengan semua materi yang sudah diberikan oleh-Nya

Mungkin karena tahta yang dijanjikan

Mungkin karena harta yang meyakinkan Mungkin juga karena wanita dengan kesetiaan Atau mungkin itu karena sebuah kesenangan

Pusing kepala ini jika aku harus terus menyelidiki Jika aku diamkan itu akan menjadi penyakit hati Berusaha diri ini menegur dan memberi materi

Tapi dari mereka selalu saja bertikai sendiri

Mungkin tamparan kecilku tak mampu untuknya

Biarlah, aku hanya bisa berdo'a kepada-Nya Agar yang diberikan kasih-Nya dan bukan teguran-Nya 


\title{
Mereka Yang Tak Belajar
}

Aku bertanya pada diriku sendiri

Sebenarnya apa yang sedang terjadi?

Bukannya aku sedang bingung

Tapi, diriku seringkali dibuat linglung

Semua yang aku inginkan selalu saja diberi batasan Sebenarnya aku tak menyalahkan, hanya saja mereka selalu mengutamakan keegoisan

Berusaha menenangkan diri memang sulit

Karena akupun memiliki keegoisan

Berimajinasi sampai jiwa ini terlilit

Tanpa satupun ada yang bisa tersampaikan

Aku tak ingin dijatuhkan

Tapi, seolah diri ini diremehkan

Aku tahu diriku selalu membuat kecewa

Tolong beri aku kesempatan sekali saja

\author{
Di dalam hati kecilku menangis \\ Berharap DIA membimbingku kembali \\ Ya Rabb, kuatkan hati yang teriris \\ Yakinkan mereka yang tak percaya pada diri ini
}

Salah memang jika diri ini berdebat dan terus membantah Jika hanya diam, aku selalu dianggap rendah seperti sampah

Seperti kataku dahulu

Menjatuhkan mental memang hal yang mudah

Tapi, apakah kamu bisa kembali membangkitkannya? 
Tersisihkan karena materi yang tak pernah didapat Sebab lemahnya diri ini karena kurangnya rasa taat

\author{
Aku tak menyalahkan mereka, \\ Tapi dilihat dari cara mereka memberikan masukan \\ Aku selalu tertatih diujung cerita \\ Hanya bisa duduk diam dan menenangkan perasaan
}

Akan berbeda jika mereka hanya membandingkan Karena menurut mereka itu yang harus aku jalankan

\author{
Inilah catatanku, Jangan kalian heran \\ Karena beginilah caraku mengekspresikan \\ Maaf jika bahasaku tak layak dipublikasikan \\ Karena ini hanyalah salinan dari sebuah perasaan
}




\section{Move On}

Waktu berlalu begitu pelan

Dan aku sadari semua telah pergi

Mencoba menahan beratnya beban

Lalui hari-hari dengan-Nya di sini

Takkan aku hiraukan semua ucapan

Berharap DIA tak meninggalkan ku

Tentukan tujuan dan terus berjalan

Menatap kedepan demi masa depanku

Sakit hati itu pasti

Tapi Move On itu harus

Kau sering berkata Move On itu sulit Itu karena kau yang memilih untuk terlilit

Sulit karena kau tak melihat arti dari tujuan Dan terlilit karena semua ucapan dan harapan

Jadikanlah masa lalu sebagai pembelajaran Jangan kembali jika memang tak tahu jalan pulang Masa lalu memang indah dan penuh kenangan Jangan kau pasrahkan diri untuk selalu dikekang

Buka mata dan buka pikiran Jika aku bisa, kenapa kau tidak bisa melakukan?

Lihatlah pelajaran dalam kehidupan Ambil dan jadikanlah semua sebagai patokan Dan ingatlah, bawalah DIA di setiap permasalahan 


\title{
Parasmu
}

\author{
Indahnya dirimu \\ Aku selalu terbayang wajahmu \\ Maaf jika dirimu tak aku puja \\ Sebab dirimu hanyalah ciptaan-Nya \\ Terima kasih ku ucapkan kepada-Nya \\ Sebab DIA begitu sempurna \\ Menciptakan dengan sepenuhnya \\ Tanpa kurang satu hal yang membuat luka

\section{Parasmu,} \\ Begitu indah \\ Sampai diriku menjadi gundah \\ Dan mulai kehilangan arah \\ Jangan bangga dengan keindahanmu \\ Jangan bangga dengan kelebihanmu \\ Semua tak ada yang berbeda \\ Hanya IMAN yang tak sama
}

DIA merencakan sebelum dunia ini ada

Jika kamu tidak bersyukur maka rugi hidupmu DIA yang mengatur semua yang ada di dunia Jika kamu hanya mengeluh maka rugi umurmu

Bersyukurlah DIA menyempurnakanmu

Bersyukurlah DIA tak menuntutmu

Karena DIA mencintaimu, maka cintailah dirimu 


\title{
Pasanganku
}

Pasangan adalah teman hidup

Tapi selalu saja membuatku gugup

Yang aku tahu itu pasti pemberian-Nya

Dan aku tahu itu terbaik untukku dari-Nya

Siapa kelak pasanganku

Aku pun tak tahu hal itu

Mereka berkata akan seperti diriku

Dan aku selalu percaya dengan hal itu

\author{
Jika aku baik \\ Maka baik pula pasanganku \\ Jika aku buruk \\ Maka buruk pula pasanganku
}

Entah di mana kita dipertemukan

Entah itu kawan baru atau kawan lama

Itu bukanlah sebuah permasalahan

Yang ku perbuat saat ini hanyalah berusaha

Berusaha menjadikan diri yang terbaik

Buat diriku dan buat pasanganku

Berusaha menjadikan diri orang baik

Buat semua orang dan keluargaku

Bersamamu adalah salah satu cita-citaku

Bersabarlah menunggu dan teruslah melangkah

Jangan sampai, cinta sesaat yang membuatmu patah 


\section{Palestine Will Be Free}

Menangis dibalik kebahagiaan yang sedang terengut Apakah mereka selalu merasa kesusahan dengan itu? Sakit yang terlihat bahkan berbekas sampai relung jiwa Apakah mereka selalu merasa sedih dengan itu? Selalu diinjak dan di remehkan harga diri mereka Apakah mereka selalu merasa tersiksa dengan itu?

The question is, "Why, we can't like that?"

Mereka berusaha bangkit dibalik keterpurukan Sedangkan Kita?

Berusaha bangkit dari percintaan saja tak bisa Mereka berusaha berdiri dibalik egoisnya kekuasaan Sedangkan Kita?

Berusaha bangkit dari keterpurukan saja tak bisa

Apakah mereka meminta kita untuk mengasihani mereka? Tidak!!!

Mereka akan selalu kuat tanpa rasa kasihan dari kita

Mereka selalu memberikan motivasi kepada kita Kita sendiri yang tidak mengambil untuk perubahan Mereka selalu mengajarkan kita akan arti perjuangan Kita sendiri yang gak peka dengan semua teguran-Nya

DIA selalu memberikan kekuatan pada hamba-Nya yang berusaha untuk berubah

Mereka adalah sederat orang yang benar-benar mengabdi kepada-Nya 
DIA selalu memberikan kebahagian pada hamba-Nya yang

sedang di landa kesedihan

Mereka adalah sederet orang yang benar-benar akan merasakan selamanya kebahagiaan

Mereka terluka hanya di dunia

Kita hanya terluka hati saja, sudah tak mau menyapa

Mereka selalu berada di dalam keterpurukan

Kita karena cinta saja sudah menyerah dan putus asa Mereka tak mengenal putus asa, karena DIA adalah alasan mereka untuk hidup

Sadarlah, kita yang selalu jatuh di dalam keterpurukan

Sadarlah, kita yang selalu jauh dari jalan-Nya

Sadarlah, kita yang selalu sedih dengan kekecewaan

Sadarlah, kita yang tak berbenah untuk diri kita sendiri

Bulatkan tekad kita seperti semangat mereka Ibadah, Hidup, dan Mati kita hanyalah untuk-Nya

Ya rabb, ENGKAU maha kuasa atas segalanya maka berikan pertolongan kepada saudara-saudari kami di sana Ya rabb, ENGKAU maha kuasa atas segalanya maka kuatkan mereka untuk terus berjuang demi nama-Mu

Saudaraku, perjuanganmu akan selalu terbalaskan dan syurga sebaiknya tempat terakhirmu

Maafkan kami yang tak bisa ikut serta dalam perjuanganmu Hanya do'a di setiap sholat kami yang bisa kami sampaikan Memohon pada-Nya agar dirimu selalu dalam penjagaan I pray, may Allah always protect all moslems in this world Aamiin 


\section{Pendidikan Yang Terlupakan}

Pendidikan adalah aspek penting kehidupan Tanpa pendidikan kita akan menabrak ketika berjalan Bayangkan jika kita buta dalam berjalan Apa kita bisa sampai menuju masa depan?

Pemikiran labil dan selalu mengabaikan Membuat kita selalu saja bertentangan Sembunyi di balik banyaknya pertanyaan Yang seharusnya membutuhkan sebuah jawaban

Tuntutlah ilmu sebanyak penamu menulis kata Tapi bagaimana caranya, jika kita terus menghiraukan Permasalahannya, selalu saja menjadi cerita Karena tempat ini selalu saja terlupakan

Aku sedih jika melihat kondisi ini "Tapi apa caraku, memperbaiki ini?" Aku sudah berusaha membuat mereka sadar Sayangnya mereka hanya diam tanpa komentar

Negeriku takkan bisa maju jika terus begini Sebagai pemuda yang haus akan pendidikan Kita selalu tak belajar dari sebuah pengalaman Akhirnya itu membuat kita jadi seperti ini

Pendidikan di negeriku selalu terlupakan Walau banyak dari mereka mengukir prestasi 
Di dalam suatu bagian akan selalu terabaikan

Pemerintah tak melihat itu semua

Karena patokan mereka yang sudah menjadi kebanggaan

Pemerintah tak merasakan itu semua

Karena mereka hanya melihat lalu pergi meninggalkan

Aku tak menyalahkan pemerintah

Tetapi selalu saja mereka lemah dalam menjalankan

Yang terabaikan akan semakin resah

Yang di utamakan akan selalu di kembangkan

Profesionalitas adalah bukti sebuah pendidikan

Tapi mereka selalu saja sombong dan mengabaikan

Loyalitas adalah bukti sebuah keikhlasan

Tapi mereka selalu saja bangga dan merendahkan

Aku tahu kalian mampu

Tapi jangan sampai kemampuanmu itu menjatuhkan mereka

Aku tahu kalian hebat

Tapi jangan sampai kehebatanmu itu kalian gunakan untuk membuat orang lebih terinjak

Aku hanya bisa bersuara melalui tulisan

Jika kalian menerima pesanku ini

Tolong sampaikan, bahwa aku akan selalu ada di sini 


\section{Penjara Dunia}

Aku pernah bersalah

Tapi, apa itu membuatku patah?

Dengan beban aku meminta maaf

Berharap semua bisa memberikanku maaf

Penjara dunia, di mana semua terkurung rapat

Tanpa ada sedikit celah untuk bisa melihat

Aku tak tahu jika diri ini bersalah kembali

Apa aku mampu menerima hukuman yang di beri?

Jujur saja, penjara dunia ini tak seberapa Dengan hukuman yang aku terima di akhirat kelak Ku kira itu seadil-adilnya adalah hukuman-Nya Aku tak mampu jika harus membayangkan di benak

DIA berkata inilah neraka jahanam Jika diri ini terus durhaka kepada-Nya Aku bisa kapan saja masuk kedalam Jika terus -menerus mengabaikan-Nya

Pedih jika aku bayangkan

Tak mampu jika itu di timpakan Baru saja aku di tegur dengan kehilangan Masih saja diri ini memaksa menjalankan

Ya, Rabb lindungilah selalu kami semua dari neraka-Mu Bimbing kami agar terhindar dari godaan syaitan Yang menghasut kami untuk masuk kedalam neraka-Mu 


\section{Percayalah}

Baru saja aku tinggalkan untuk melanjutkan tulisanku

Tak ku sangka terjadi gemuruh di dalam rumahku Suasana berubah menjadi sunyi dan senyap seketika Aku ikut terdiam dan tak tahu yang terjadi sebenarnya

Ketika aku bertanya "sebenarnya apa yang terjadi?" Dengan nada cemas dia berkata "sudahlah lupakan" Aku pun mengabaikan dan mulai menyelidiki Sebenarnya apa yang sudah aku lewatkan

Aku tak mendengar semua begitu jelas Mungkin karena musik ku terlalu keras Tapi dari caranya berbicara, dia sedang dimarahi Dengan senyum aku menggelengkan kepala ini

Ternyata permasalahannya adalah sebuah kecemburuan Cemburu akan hadir karena itu bagian dari kepercayaan

Aku tak tahu dan aku mulai mengabaikan Ketika bicara tentang kepercayaan dan kecemburuan Kalau sudah pacaran Takkan ada namanya kepercayaan

Yang selalu ada adalah praduga di luar logika Yang muncul seolah mempengaruhi jiwa dan raga

Ketika aku setia dengan mudah aku disakiti Ketika aku percaya dengan mudah aku dikhianati

Entahlah, hubungan itu selalu saja rumit Mau diapakan lagi selalu saja menjadi sulit 
Karena di dalam situ akan selalu ada praduga Yang hadir tanpa memikirkan realita yang sudah ada

Mulutnya keras seperti pinggiran asbak Percuma kalau berjanji jika selalu di ingkari Sampai jantung berhenti dan mata terbelalak Takkan mudah untuk mereka percaya kembali

Percayalah kepada-Nya yang selalu mendampingi

Percayalah kepada-Nya yang pantas di yakini

Percayalah kepada-Nya yang selalu memberi

Percayalah kepada-Nya yang selalu menyayangi

Tapi sayangnya kau selalu mengingkari

Semua yang telah DIA beri

Ketika kita terlalu percaya kepada mereka yang tak memiliki kuasa

Sadarlah dan segera kembali Jangan sampai DIA memberi teguran kepadamu

"Dan diantara manusia ada orang-orang yang menyembah tandingan-tandingan selain DIA; mereka mencintainya sebagaimana mereka mencintai DIA.

Adapun orang orang yang beriman amat sangat cintanya kepada DIA. Dan jika seandainya orang-orang yang berbuat dzalim itu mengetahui ketika mereka melihat siksa (pada hari kiamat), bahwa kekuatan itu kepunyaan DIA semuanya, dan bahwa DIA amat berat siksaan-Nya (niscaya mereka menyesal)"

$(2: 165)$ 
Perkataan mereka memang pedas

Tapi ingatlah, itu sebatas didunia saja

Tak perlu kau dengarkan itu semua Ambil saja jika itu perlu dan buanglah jika itu tak perlu

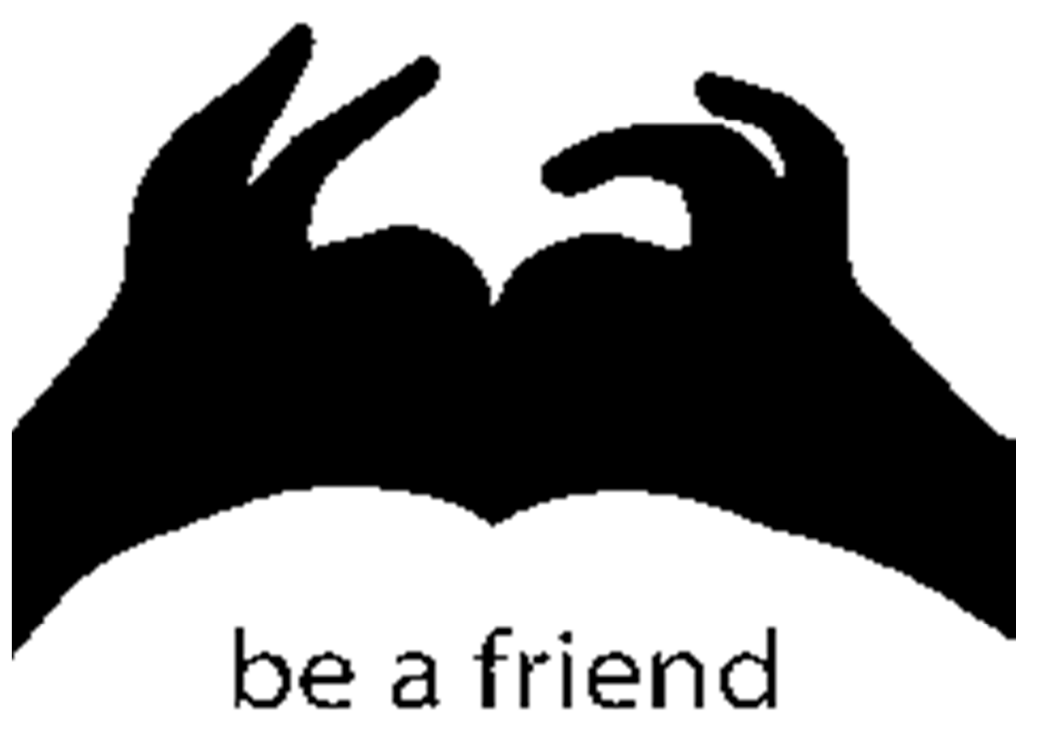




\section{Pernikahan}

Sebab pernikahan adalah suci

Janganlah kamu menyulitkan diri

Selalu saja kita dibuat riwuh dengan ini

Dengan alasan, ingin menjadi momen inti

Aku tak tahu maksud mereka membuat ini

Mereka melakukan semua dengan sepenuh hati

Tapi, apa endingnya dari pernikahan ini?

Berkesan tidak, malah akan selalu membuat iri

Pernikahan itu sangatlah mudah

Tapi kita sendiri yang membuat susah

Mereka berkata "kamu kan belum menikah?"

"jadi jangan sesekali bilang itu mudah"

Sayangnya mereka tidak mengambil cermin

Untuk berkaca melihat yang sudah terjadi

Mereka selalu berlomba menjadi orang lain

Dan takkan bisa menjadi diri mereka sendiri

Menikahlah ketika kamu siap untuk menikah Jangan berlagak, kalau memang belum siap menikah

Apa pelajaran dari sebuah pernikahan?

Jika kamu sendiri bingung cara menjalankan

Jangan lagi kamu membuat itu menjadi sebuah beban Satukan jalan demi satu tujuan, ingat ini bukanlah sebuah permainan yang dijadikan ajang pameran 


\section{Perselingkuhan}

Sebab cinta itu rapuh

Jadi jangan di buat riwuh

Ini juga termasuk problem dalam cinta Jelas akan ku bahas sampai ke akarnya

Berbicara tentang perselingkuhan "Kenapa itu bisa terjadi dalam hubungan?" Sebab perselingkuhan hanyalah permainan Yang diciptakan demi sebuah kepuasan

Pelakor dan Pebinor, Mereka adalah spesies baru dalam hubungan Jika kita tak benar-benar, maka tinggalkan Bukan malah melakukan perselingkuhan Itu hanya akan memberikan kekecewaan

Janganlah membangun hubungan Jika hati masih saja terbayang akan kesenangan Janganlah membina hubungan Jika hati kita saja masih suka membayangkan

Melihat yang lebih indah dari miliknya Itu sudah biasa terjadi dan menjadi problema Itulah sifat manusia yang harus dikendalikan Bukan dengan itu kita malah membuat permainan

Babak baru dalam percintaan yang palsu Dengan alasan tidak puas dalam hubungan itu

Perselingkuhan bukan hanya problema Melainkan itu sebuah penyakit cinta 
Melihat drama dalam perselingkuhan saja Membuatku lupa bahwa itu hanyalah fana Mereka yang masih suka melakukan itu Takkan bisa puas jika mereka terus begitu

Sebab kepuasan cinta Adalah saat kita bisa bersama Yang pastinya dengan mereka yang kita cinta Dengan ketulusan tanpa ada yang memaksa

Jagalah hatimu dari keinginan ini

Sebab hanya hati yang bisa menjauh Logika takkan pernah bisa mengerti Sebab kepada hati kita harus patuh

Maka setialah dirimu kepada-Nya sang pemilik cinta Jika kau setia pada-Nya, pasanganmu pun begitu Tapi ingat, ini bukan untuk pemuda yang dilanda cinta Melainkan untuk mereka yang sudah berani bersatu

Bersatu dalam mahligai pernikahan Maka hindarilah sebuah perselingkuhan Jangan percaya dengan bualan syaitan Yang mengajak buruk dalam hubungan 


\section{Pertemuan Singkat}

Di persimpangan jalan aku bertemu Kamu melempar senyum dan aku membalas

Di suatu waktu aku memikirkanmu Berharap kamu sesegera mungkin membalas

Pertemuan singkat itu membuatku terbayang

Timbul satu pertanyaan dalam benakku "Apa aku bisa bertemu di waktu yang akan datang?" Mungkin hanya waktu yang bisa menjawab itu

Pandangan pertama yang membuatku terkesima Dengan keindahan dirimu yang sangat sempurna

Maaf aku tak bisa memuji keindahanmu Karena DIA yang pantas mendapatkan itu

DIA sebaik-baik pencipta Rugi jika kita masih jauh dengan-Nya Selalu saja kita memuji ciptaan-Nya Dan sedikit bersyukur kepada-Nya

Pertemuan singkat itu akan ku kenang selalu

Takkan ku lupa walau sudah lama berlalu Senyuman yang hangat dari dirimu Menambah semangat dalam hidupku

Semoga bisa terulang kembali di suatu waktu Entah di mana kita akan bertemu Aku harap kamu masih sama seperti yang dahulu 


\title{
Pikiran Mereka
}

Jika aku ditanya "dari mana sumber pikiran itu?" Pikiran yang selalu diikuti oleh perbincangan syaitan Aku menjawab "tentu saja dari pola berfikirmu" Karena pola berfikir yang membangun percakapan

\author{
Jangan sampai karena pikiran itu \\ Membuatmu semakin jauh dari-Nya \\ Berbicara baik takkan merugikanmu \\ Jadi belajarlah selalu karena-Nya \\ Pikiran setiap orang berbeda-beda \\ Tapi jangan jadikan itu problema \\ Satukan dengan satu tujuan \\ Dan jadikan satu keinginan
}

Mereka selalu saja menyalahkan materi Materi yang dibahas dalam berbagai sisi Aku merasa lucu dengan hal itu Sangat tak berguna buat diriku

Sejauh mungkin menghindar Selalu saja aku dibuat buyar Pelan-pelan akan ku ubah pemikiran mereka Yang selalu berbicara hal yang tak ada esensinya

Sumber pikiran yang bisa mengatur pembicaraanmu Jadikanlah itu hal yang berguna

Sebab Diam itu emas dan berbicara baik itu Berlian 


\section{Pilihan-Nya}

Di saat mentari hadir aku berdo'a Berdo'a agar DIA memilihmu untukku

Walau do'aku sedikit memaksa Apapun pilihan-Nya itu terbaik untukku

Jika kelak aku tak bersamamu Itu bukan masalah buatku Aku tahu itulah yang terbaik untukku Dan yang pastinya terbaik untukmu

Jika kelak kamu tak bersamaku Itu bukan masalah buatku

Aku tahu bahagiamu, bahagiaku juga Untuk apa aku merasa kecewa dengan-Nya

Pilihan-Nya akan selalu yang terbaik Sekalipun itu sulit, tapi untukmu itu baik Jika kamu ragu denganku itu hal yang biasa Karena aku hanyalah salah satu ciptaan-Nya

Jangan sesekali kamu mengambil pilihan Yang selalu bertentangan dengan suara hati Curhatlah kepada-Nya jika itu meragukan Meragukan keputusan yang kamu ambil nanti

DIA selalu memberi sebelum kamu meminta Maka yakinkan DIA, jika kamu ingin diriku Dan aku akan meyakinkan-Nya bahwa ku menginginkanmu 


\title{
Rahasia Allah
}

Ada jalur di mana kamu tak berhak menjangkaunya

Yaitu iman kepada qada dan qadar

Allah tak pernah memaksamu untuk tunduk pada-Nya

Hanya saja kamu harus peka dan sadar

\begin{abstract}
Rahmat Allah itu sudah pasti
Sedangkan kamu masih kalah dengan hati

Hatimu selalu kamu berikan untuk makhluk-Nya

Tak pernah sedikit saja kamu luangkan untuk-Nya
\end{abstract}

Aku memilih sendiri bukan berarti aku sendiri

Sebab DIA akan selalu menemani hati yang sepi

Rahasia Allah selalu menjadi pernyataan hati

Karena hanya hati yang dapat menerima dan mengerti

Jika kamu sedang sendiri

Percayalah dirimu tak pernah sendiri

Jika kamu sedang ragu

Percayalah dan kuatkan selalu yakinmu

Rahasia Allah terletak pada kepuasan hati

Ketika kamu merasa lapang dan bahagia

Rahasia Allah terletak pada kekuatan hati

Ketika kamu merasa DIA sebaiknya pencipta

Aku berbicara seperti ini karena aku sama sepertimu

Selalu lemah dan rapuh jika hanya memuaskan nafsu

Aku berbicara seperti ini bukan karena aku sempurna Hanya saja aku dan dirimu akan selalu sama di mata-Nya 


\section{Rasaku}

Rasaku,

Perasaan itu selalu menyiksa

Menyiksa karena selalu memaksa

Dan memaksa karena ingin dilihat mata

Rindu mungkin nama samaranmu

Tapi aku sering menggunakan itu

Ketika kamu datang menyambutku

Untuk sejenak bercerita tentang waktu

Rasaku,

Hati selalu saja berbenturan

Berbenturan dengan pemikiran

Dan merusak semua tatanan kehidupan

Menghindar, mungkin caramu

Tapi cara itu salah menurutku

Ketika kamu datang kepadaku

Untuk sejenak melepas beban hidupmu

Aku sampaikan rasaku ini hanya kepada-Nya

Karena hanya DIA-lah pemilik segala-Nya

Semoga DIA selalu mendengar apa do'aku

Dengan itu aku dapatkan kebahagiaanku

Rasaku takkan tersampaikan

Jika aku hanya berdiam diri dengan penuh harapan

Berusaha akan aku lakukan dan akan aku jadikan DIA

sebagai tempat pengharapan 


\title{
Rezeki Yang Terlupakan
}

Sempat terfikir untuk meninggalkan

Tapi sayangnya aku masih dibutuhkan

Membantu mereka menuju jalan-Nya

Tapi sayang selalu ada kesulitannya

Kita tak pernah berfikir atas nikmat dari-Nya

Yang kita fikirkan hanyalah nikmat lainnya

Kita tak pernah berterima kasih kepada-Nya

Karena selalu merasa kurang atas pemberian-Nya

Begitulah manusia, selalu lalai dalam kehidupan

Mereka tahu dunia ini hanyalah fatamorgana

Tapi mereka selalu saja melupakan

Dengan semua pemberian dari-Nya

\author{
Nikmat sehat \\ Nikmat Iman \\ Adalah rezeki yang terlupakan \\ Dan selalu saja diabaikan
}

Tanpa terima kasih kita ucapkan

Selalu saja memohon minta diberikan

Selalu meminta karena ketidakpuasan

Padahal selalu lupa dengan kewajiban

Beruntung DIA maha baik, maha penyayang

Seandainya DIA tak baik, kepada siapa kita meminta?

Bersyukurlah dirimu, selagi kamu mampu mengatakannya 


\section{Sa ada Karena DIA}

Sa cuma punya satu hati

Karena itu yang mampu sa beri

Dengan rasa yang suci

Sa mohon ko bisa pahami

Walaupun, DIA adalah segalanya

Namun sa minta pada-Nya agar rasa ini selamanya

Dengan penuh kemudahan

Yang pasti tanpa kekecewaan

Berjuang tetap banggakan ko

Hanya karena itu, sa ada untuk ko

Cinta bukan harus torang liat dari fisik

Hanya sebatas pilihan bukan harta yang berbisik

Sementara sa pu harap mengalir

Sa banggakan ko setiap awal dan akhir

Sa bermimpi, torang hidup bahagia

Seindah malam ini, ko adalah karunia

Ko jadi motivasi agar trus menata Jika bukan baik, harap ko bisa buka mata

Cinta bukan pandangi derajat dan harta

Tapi hati, buat air keluar dari mata

Sa hidup sempurna karena ada DIA

Tapi, sa rasa kurang, kalau ko tidak ada

Jadi sa berdo'a biar sa dan ko bisa bersama 


\section{Sakit Tapi Tak Berbekas}

Terbayang akan dirimu yang jauh di sana Menyakiti dengan kejamnya tanpa logika Aku bingung saat kamu menyakitiku Bingung dengan tujuan dan maksudmu

Sejujurnya luka ini memang tak berbekas Tapi, sungguh sakit sampai ke relung jiwa Sejujurnya luka ini memang tak berbekas Tapi sungguh, kamu takkan bisa ku percaya

Berjalan ditengah malam tanpa bintang Bulan pun terlihat sembunyi dibalik awan Aku memanggilmu tapi kamu tak datang Akhirnya aku terpuruk dalam kesendirian

Sejujurnya, aku bisa saja menyakitimu lebih dari ini Tapi sayangnya aku tak mampu menyakitimu Sejujurnya, aku bisa saja lebih kejam dari pada ini Tapi sayangnya hatiku selalu menentangku

Kamu bagaikan bunga di ujung jurang Jika ku ambil, resiko berat menjadi pilihannya

Kamu bagaikan buih di dalam gelombang Jika ku ambil, maka aku akan hilang ditelannya

Sering sekali kamu membuatku sakit hati Tapi aku tahu, memang salah hubunganku ini Aku hanya sedikit kecewa dengan dirimu Tapi perlahan aku akan mulai melupakanmu 
Sakit ini memang tak berbekas

Tapi kelak akan menimbulkan bekas

Berbekas karena mengingat kenangan

Tapi tenanglah, aku akan berusaha melupakan

Jika ditanya "apa sakit ini bisa hilang?" Hanya hati dan perasaan yang bisa mengatakan Jika ditanya "bagaimana caranya bisa hilang?" Mungkin hanya DIA yang bisa menjadi alasan

DIA yang selalu membantuku menyembuhkan luka Jadi tanyakan saja pada-Nya, jika kamu ingin tahu caranya

\author{
Maafkan aku, \\ Karena aku selalu salah dalam membina hubungan \\ Maafkan aku, \\ Karena aku selalu tak peka dengan semua teguran
}

Terima kasihku pada-Nya

Akan selalu terucap

Karena berkat-Nya, aku kembali 


\section{Sedih dan Bahagia}

Sebuah rasa di dalam hati yang sulit diceritakan Membuat kita terkadang selalu ingin menceritakan

Terkadang kita berusaha mencari kebahagiaan Padahal, bahagia itu selalu ada dibalik kesedihan

Allah adalah dzat yang paling sempurna Karena ikhlas dan sabar adalah kunci bahagia DIA memberikan rezeki sesuai dengan porsinya Kita harus pandai dalam mensyukurinya

Kita selalu menyesal ketika sedih melanda Dan lupa dengan-Nya ketika bahagia menyambut kita

Kita selalu terhenti dalam langkah perjuangan Dan lupa dengan-Nya ketika hasil sudah kita dapatkan

DIA akan selalu mengasihi kita dengan seluruh kasih Kita yang selalu mengabaikan dan terjerat di dalam perih DIA takkan berhenti dalam memberi rezeki-Nya Walaupun kita tidak pernah mau mensyukurinya

Sedih dan Bahagia adalah komposisi

Yang seimbang tanpa lupa di mana posisi

Komposisi dalam meningkatkan keimanan

Dan posisi di mana kita seharusnya merasa nyaman

Mungkin kita merasa nyaman dengannya

Tapi percayalah ketika kita bersama-Nya Kita akan mendapatkan semuanya 


\section{Sebuah Rahasia}

Memendam mungkin tak baik

Tapi begitulah yang aku bisa

Biarlah aku jaga ini baik-baik

Agar kelak tak merusak suasana

Aku bersyukur kepada-Nya

Dan pada akhirnya kita berjumpa

Entah di mana disuatu tempat

Yang pasti aku akan semakin taat

Berjuang menjadi imam yang baik Untukmu, dan semua keluargaku

Belajar menjadi seorang yang terbaik Untukku, dan semua keluargamu

Menahan semua rasa yang ada Hingga waktu yang sudah ditentukan

Berjalan ikhlas dan selalu berdo'a Hingga DIA memberikan keputusan

Sebuah Rahasia memang bersifat rahasia Karena DIA sudah mengatur semua

Ini adalah Sebuah Rahasia

Cukup aku, kamu dan DIA yang mengetahuinya

Cukup aku simpan semua

Dan kelak aku ceritakan kepada anak-anak kita 


\section{Self Reminder}

Sehela nafas yang aku hembuskan adalah nikmat Segelas kopi yang ku teguk juga sebuah nikmat

Panorama yang aku nikmati sangatlah indah Terlalu menikmati sampai membuatku kehilangan arah

Di atas sajadah aku bersujud dan berdo'a Berharap semua akan baik-baik saja

DIA yang menghidupkan

DIA juga yang mematikan

Berikanlah sesuatu jika dia memang berhak Maka Lindungilah sesuatu jika memang itu hak Belajar dari kesalahan membuat kita terlatih Tapi, jangan sampai kita merasa letih

Sampai habis nafasku Sampai habis umurku Aku hanyalah hamba yang berlumur dosa Dan aku tak lebih baik jika berjalan tanpa-Nya

Larangan dari-Nya cukup aku jauhkan

Dan aku lakukan semua yang diwajibkan Berusaha mengubah diri agar menjadi manusia Manusia yang berakhlak baik hingga akhir usia

Jika kalian melihat diri ini begitu patuh kepada-Nya Aku memohon kepada kalian jangan puji diriku Jika kalian melihat diri ini durhaka kepada-Nya Aku memohon kepada kalian jangan caci diriku 
Do'akanlah yang terbaik

Karena apa yang dikatakan orang lain, hanyalah sebatas perkataan didunia saja, takkan bisa membuatmu jatuh sampai jauh kealam sana

Media sosial selalu membuatku depresi

Aku merasa memiliki banyak teman di sana

Tapi realitanya aku selalu merasa sendiri

Bagaimana kehidupanku jika aku tak mencoba

Temanku berkata kepadaku,

Kita tidak bisa mengubah masa lalu

Kita hanya bisa memperbaiki masa lalu

Agar lebih baik di masa depan

Dan tidak terpuruk di hari kemudian

Hiraukan apa yang membuatmu terjatuh di masa lalu Dekatkan dirimu dengan DIA Kelak dirimu akan selalu baik-baik saja

Mungkin kau tidak bisa melupakan masa lalu yang begitu suram

Tapi bukan berarti suram, masa lalu itu tak bisa di perbaiki di masa depan

Bismillah dan patahkan semua halang rintangan itu Yakinkan bahwa dirimu mampu melakukan semuanya 


\title{
Semua Tak Sama
}

\author{
Aku, kamu dan dirinya berbeda \\ Berbeda karena kepala kita memang tak sama \\ Jangan kamu samakan aku dengannya \\ Karena yang aku tahu, aku bukan dirinya
}

\begin{abstract}
Jika dirimu pernah disakiti olehnya
Jangan jadikan bahan untuk menyandung kakimu sendiri

Jika dirimu pernah dikhianati olehnya Jangan jadikan orang lain sulit untuk kembali berbagi
\end{abstract}

Semua tak sama dihadapan

Jika kita selalu memiliki keterbukaan

Semua tak sama disetiap kondisi

Jika kita selalu mencoba untuk mengerti

Aku, kamu dan dirinya

DIA menciptakan kita untuk saling melengkapi

Antara satu dengan lainnya

Kita akan sulit menyatukan persepsi jika menggunakan ego sendiri

Semua tak sama

Karena aku, kamu dan dirinya tak seirama

Bagaimana bisa seirama

Jika selalu mengunggulkan sebuah cerita

Seolah dia adalah orang yang selalu salah

Dan dirimu selalu benar dalam semua kondisi

Aku ingin kita selalu berjalan searah agar tak terpisah

Terpisah hanya karena kita selalu berbeda persepsi 


\section{Setia Itu Berharga}

Sebab setia itu berharga Bukan hanya denganku

Tapi juga setia dengan-Nya Itu yang dibutuhkan dirimu

Jika dirimu hanya setia denganku Jangan berharap kasih dari-Nya Jika kamu setia, aku sama sepertimu Hanya berharap yang terbaik dari-Nya

Bukan hanya di dunia saja Tapi sampai akhir kehidupan Bukan hanya omongan belaka Tapi harus benar di buktikan

Sebab setia itu berharga Janganlah kamu permainkan Kamu harus yakin dan percaya Jika setia ini akan terus bertahan

Belajar dari kisah di masa lalu Kita sering membahas masalah setia Seharusnya itu adalah hal yang tak perlu Jika dengan-Nya kita setia, maka setialah pasangan kita

DIA adalah perantara kita

Janganlah kita ragu dengan keputusan-Nya Setia dahulu kepada-Nya, sebab setia itu berharga 


\title{
Sifat dan Watak
}

Sifat mungkin saja bisa berubah

Contohnya aku yang diperbaiki olehmu Sedang watakku takkan mudah diubah Jika aku tak mau mengambil pelajaran darimu

Allah takkan mengubah seseorang jika orang itu tak mau mengubahnya sendiri

Allah pun selalu memberi hidayah melalui orang-orang yang penting dalam kehidupan ini Sayangnya itu diabaikan dengan mudah, dan beranggapan aku tetaplah aku

\author{
Mungkin benar katanya \\ Kamu akan selalu sama dengannya \\ Entah apa persepsinya \\ Percuma jika aku terus berbicara
}

Aku dahulu seorang yang buruk Kini dia hilangkan watak agar aku tak terpuruk

Aku berterima kasih kepadamu Karena sudah banyak mengubahku

Allah memberikan setiap kepala berbeda Berbeda juga cara berkomunikasi setiap manusia Jika kamu menganggap semua manusia itu sama Kamu tidak akan menemukan yang namanya rahasia

Sifat dan watak

Sepasang kata yang sangat memiliki banyak makna Kenyamanan seseorang bisa diukur dari sifat dan wataknya 


\section{Something on You}

Aku melihat sesuatu di dalam dirimu Yang tidak pernah dirimu tahu sebelumnya Aku yakin itu adalah kemampuanmu Sudah pasti itu semua pemberian dari-Nya

Ada sesuatu di dalam dirimu Jika bercermin kamu tak mampu Bagaimana bisa kamu mengerti kemampuanmu Dan mengerti apa saja yang dibutuhkan olehmu

Ada sesuatu di dalam dirimu

Jika kamu pandai, kamu pasti tahu

Bagaimana bisa kamu tahu tentang dirimu Jika dirimu selalu membandingkan orang sekitarmu

Aku, kamu, dan mereka Memiliki kelebihan dan kekurangan Janganlah kamu memaksa Sebab manusia pasti berbeda tujuan

Sesuatu di dalam dirimu Akan selalu tersembunyi

Jika dirimu tak berusaha mencoba untuk menemukannya Aku yakin, kamu akan terus menatap kehidupan mereka

Allah memberikan lebih dalam kehidupanmu Aku harap, kamu bisa mempergunakan itu Jadilah orang yang selalu bermanfaat Agar mudah menjadi orang yang taat 


\section{Speechless}

Mati gaya ku karenamu

Mati kata ku bersamamu

Itu yang ku rasakan

Sangat sulit dijelaskan

Berkali-kali kepalaku dibenturkan Oleh kata-kata yang sangat menyakitkan Tapi aku tahu, tujuannya adalah kebaikan Agar diriku selalu baik di masa depan

Berkali-kali aku dibuat terdiam Karena statement tanpa pertanggungjawabkan

Tapi aku tahu, aku takkan tenggelam Karena dirimu hanya berusaha mengingatkan

Berkali-kali aku dibuat termenung Karena perkataan yang selalu menggantung Walau sebenarnya itu bisa dibenarkan Tetap caraku menyampaikan tetap disalahkan

Aku speechless ketika dirimu hadir Entah kenapa itu bisa terjadi Yang aku tahu, mungkin ini bagian dari takdir Agar aku selalu tak mengomentari

Gak nyambung sih, dari atas sampai bawah Tak apalah, mungkin karena aku sedang tak tahu arah Aku harap kamu bisa paham apa yang aku sampaikan Walau kadang aku terdiam saat mencoba menjabarkan 


\title{
Strategi Syaitan
}

Semua hal yang kita lakukan

Di dalam akan selalu ada syaitan

Mereka berlomba-lomba menghasut

Agar manusia tidak menjadi penurut

Mengikuti perintah-Nya adalah keharusan

Mengikuti perintah-Nya adalah pilihan

Menjadi baik itu adalah pilihan Jangan takdir yang selalu disalahkan

Terkadang kita sering kali menyalahkan syaitan

Padahal kita sendiri yang mau melakukan

Tanpa ada paksaan, karena itu janji syaitan

Terus menghasut sampai akhir kehidupan

Percintaan yang palsu dibuatnya indah Agar manusia mudah kehilangan arah

Bukan salah yang menciptakan

Jika manusia selalu menghiraukan

Panggilan dari-Nya selalu kita abaikan Dengan alasan materi sebagai jaminan Itulah salah satu strategi dari syaitan Yang membuat manusia melupakan

\author{
Berlindunglah selalu kepada-Nya \\ Mintalah kemudahan agar di jauhkan darinya \\ Karena syaitan akan menyerang dari sisi mana saja
}


Relationship adalah hubungan yang dibangun demi sebuah kebahagiaan Dicapai dengan kerja keras Dinikmati untuk waktu yang bersifatnya tidak hanya sementara

Hubungan dibangun dengan cara-Nya Berbaiklah selalu untuk menjaganya

Tapi, jangan sampai dirimu mengabaikan hubungan kepada-Nya

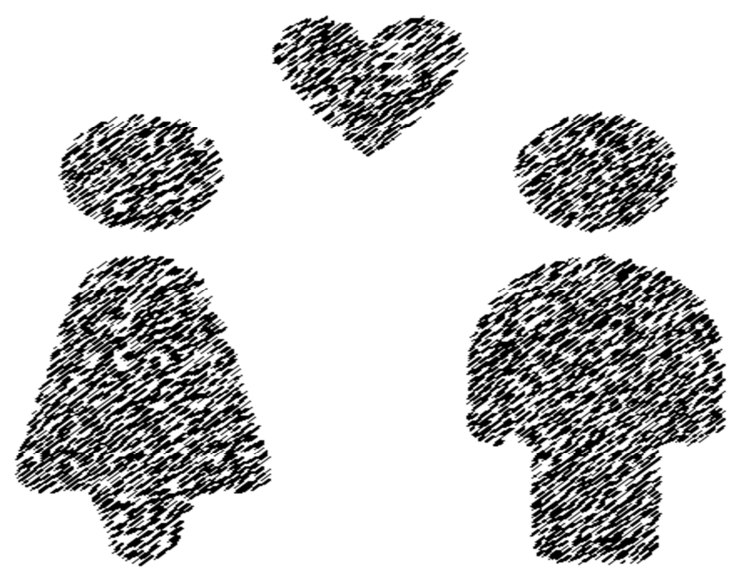




\section{Taubatku}

Aku adalah pendosa yang hebat

Salahkah jika diri ini bertaubat?

Dosaku takkan bisa dihitung

Dan amalku masih bisa dihitung

Sebab dosa takkan hilang tanpa taubat

Maka dari itu, jangan pernah berhenti bertaubat

"Berusaha takkan aku ulangi lagi"

Itu yang sering aku katakan sebagai janji

Tapi selalu, diri ini tak bisa terkendali

Selalu saja kalah dengan diri sendiri

Karena derasnya nafsu yang mengikuti

Membuatku terjatuh dalam masalah ini

Semua adalah seorang pendosa

Tak ada manusia yang tak berdosa

Jadi mohonlah pada-Nya saat ini

Agar semua dosamu di ampuni

Berharap tak ku ulangi lagi

Karena aku tahu pedih sekali balasan-Nya

DIA akan selalu mengampuni

Jika diriku benar-benar berubah karena-Nya

Ampunilah segala dosaku Ya Rabb,

Jangan KAU masukkan diri ini kedalam neraka-Mu

Karena aku takkan mampu merasakan semua siksaan-Mu 


\title{
Teman Bahagia
}

Aku percaya, suatu saat akan ada teman bahagiaku Aku percaya, teman bahagiaku bukan hanya kamu Karena Teman Bahagiaku adalah keluarga Yang menyatu karena tujuan yang sama

\author{
Maukah dirimu, \\ Menjadi teman bahagiaku? \\ Sudikah diriku, \\ Menjadi pelengkap imanmu?
}

Aku tak mau memaksanya Biarlah DIA yang akan memastikan itu Aku tak mau membuatmu terlena Dengan janji palsu yang keluar dari mulutku

Janji suci yang kelak akan aku dan dirimu katakan

Diperlaminan kita sebagai tanda bersama Dan akan ku yakinkan dirimu takkan aku kecewakan Karena dari awal itu adalah tujuan kita

Teman bahagia bukan hanya di dunia saja Tapi aku ingin menjadi teman bahagia hingga akhirat Teman bahagia yang selalu menerima apa adanya Menerima segala kekurangan agar kita menjadi taat

Terima kasih,

ENGKAU hadirkan dirinya di dalam hidupku Aku berjanji pada-Mu, takkan sia-siakan lagi seperti dahulu 


\section{Tentang Mantan}

Mantan adalah orang yang pernah kita sayangi

Yang pastinya mantan dalam hubungan pacaran

Dan dari mereka masih ada yang memilih kembali Yang pastinya membina hubungan dengan mantan

Tertunduk layu ketika aku bertemu Dengan mereka yang pernah berhubungan denganku

Walau hubungan sengaja di akhiri

Sudahlah, jika aku pernah salah, maafkan diri ini

Mata ini tak ingin menatap, tapi hati ini memaksa Tapi tenanglah aku hanya sedikit bertanya tentangmu Hati yang memaksa takkan pernah sanggup membuka

Membuka lembaran dalam menjalani kehidupanku

Orang sering mengistilahkan "gak bisa move on" Sebenarnya simple aja sih, "kalau ingin move on" Anggap aja itu sudah berlalu dan tidak akan kembali Jangan memaksa hatimu untuk terus mengikuti

Hubungan yang selalu salah akan berujung perih Jangan lagi kamu membantah statementku ini Selalu saja di sakiti, tapi tak pernah merasa pedih Jalani kesendirian terus tabah di dalam hati

Tentukan tujuan dan teruslah belajar Sakit hati itu pasti, tapi Move On itu harus 


\section{Tentang Pacaran}

Ini bukanlah pelampiasan

Aku katakan jangan pacaran

Itu hanyalah sekedar omongan

Dan hubungan penuh kepalsuan

Pacaran itu hubungan bullshit Hanya akan membuat hati semakin sakit

Tanpa akad kita bebas melakukan

"Apa gunanya Akad kalau kita pacaran?"

Pacaran itu hubungan yang di salahkan Masih saja mereka membela untuk membenarkan Itu hanyalah kegiatan penuh dengan kesenangan

Yang hanya akan menghadirkan kekecewaan

Apa yang kamu lakukan bersama pacarmu

Wallahi, DIA tahu semua tindakanmu

Sekali kamu bersembunyi di balik batu

Tak bisa kamu menyembunyikan itu

Jaga dirimu dari hubungan ini

Karena semua milikmu adalah milik jodohmu

Jangan sesekali kamu tawarkan diri

Karena dirimu adalah cerminan dari jodohmu

Bersabarlah dalam kesendirianmu

Bawa DIA, dalam setiap masalahmu

Sebab DIA yang paling mengerti dan setia bersamamu 


\title{
Tentang Rindu
}

Rindu,

Kata mereka itu berat

$\mathrm{Ya}$, memang berat bagi mereka yang tak mampu

Tak mampu menahan beratnya rindu

Terkadang kita pandai membohongi diri Dengan perasaan yang terus di sembunyikan Tapi sayangnya kita selalu lemah menghadapi Dan rapuh di ujung jalan dengan kekecewaan

Rindu itu tak harus tersampaikan Alihkan sejenak dan jangan terlalu di fikirkan Jika memang kamu merindu cukup do'akan Jangan menggumam di balik kesendirian

Merindukannya adalah kebenaran yang tak menyenangkan Tapi mencintainya adalah kebenaran yang menenangkan

\author{
Berbicara tentang rindu \\ Sangat luas dan sulit di jelaskan \\ Karena argument akan selalu beradu \\ Jangan putus asa jika tak tersampaikan \\ Seharusnya, kamu merindukan kasih-Nya \\ Seharusnya, kamu merindukan cinta-Nya \\ Bukan kasih yang sifatnya hanya sementara \\ Yang pasti akan meninggalkanmu selamanya
}

Sering sekali aku mendengar Rindu dengan seseorang yang di sayang 
Entah itu salah atau benar

Orang yang di sayang itu bukan hanya seorang

Terkadang juga rindu di jadikan alasan

Mengingatnya di balik indahnya kenangan

Tapi itulah persepsi mereka yang sering merindu

Aku hanya bisa terdiam karena aku juga begitu

Sudahlah, tidak usah terlalu di pusingkan

Ini hanyalah persoalan dari perasaan

Jika kita bisa mengendalikan hati

Maka mudah juga membawa diri

Ingatlah DIA jika kamu sedang merindu

Sampaikan rindumu selalu pada-Nya

Kelak DIA akan menghadirkan rindu itu padamu Intinya, cukup yakinkan dirimu selalu pada-Nya

Jangan bingung soal rindu

Karena rindu adalah sifat manusia juga

Tak ada manusia yang tak merindu

Seperti Nabi yang juga merindu kepada istrinya

Jadikanlah rindu itu sebagai berkah dalam kehidupan

Kelak kamu akan merasakan bahagia di hari kemudian

Aamiin 


\section{Terabaikan}

Aku kembali di lupakan

Seolah diri ini terjauhkan

Memang itu salahku sendiri

Tak pernah peka dengan apa yang di beri

Aku melihat ekspresinya itu Sangatlah tak bersemangat menurutku Wajah polosnya sudah jelas membisu

Seakan tak ingin sekali di ganggu

Aku berjalan melalui lorong itu

Dua kucing itu masih saja melihatku

Aku masih bingung dengan tatapannya

“Apa aku salah memberi harapan kepadanya?"

Derasnya mata air di sungai itu

Selalu membuatku termenung karena masa lalu

Mencoba menyakinkan diriku Hanya ombak di pantai itu yang bisa menenangkanku

Sinar rembulan selalu menemaniku Berjalan bersama menghabiskan waktu

Tak apa jika aku sering terjatuh Aku yakin semangatku takkan runtuh

Kata-kataku yang tak berirama

Tulisanku yang selalu tak bermakna

Mengubah kondisi dari hampa menjadi lebih berwarna Agar semua terisi dengan posisi yang seharusnya 
Belajar peka bukanlah hal yang mudah Harus kuat hati kalau tak ingin patah Memang rumit jika berbicara tentang kepekaan

Aku sendiri tak pandai dalam merasakan

Tak banyak kata yang bisa aku katakan Jika diri ini selalu saja menghiraukan Tak banyak tulisan yang bisa aku sampaikan Jika diri ini tak mau mengambil pelajaran

Aku terabaikan karena aku tak mau belajar Memaksa kondisi untuk selalu berdiri tegar Aku terabaikan karena terlalu mementingkan diri Bukan karena mereka, tapi karena diriku sendiri

Berbicara tentang rasa Kamu takkan bisa mengerti jika hanya berbicara Berbicara tentang hati Kamu takkan bisa mengerti jika hanya menyakiti

Hei, it's me Please don't forget me I need you, to help me 


\section{Terima Kasih}

Terima kasih atas rasamu untukmu Terima kasih atas belaian kasihmu Rasa yang selalu tulus kamu berikan Kasih suci tanpa ada kekecewaan

Kamu membuatku semakin bersemangat Dan selalu membuatku ingin selalu dekat Kamu membuat diri ini merasa sangat nyaman Walau terkadang selalu timbul pertanyaan

Bersemangat untuk menjalani masa depanku Ingin sekali dekat karena kamu adalah ciptaan-Nya

Rasa nyaman yang selalu hadir saat bersamamu Pertanyaan yang timbul dan selalu menjadi tanda tanya

Terima kasih ku ucapkan untukmu

Yang selalu mencintaiku apa adanya

Terima kasih atas kasih tulusmu

Yang selalu ikhlas kamu berikan kepada-Nya

DIA adalah perantara kita

Dan kita adalah makhluk yang paling dicinta oleh-Nya Maka terima kasih ku ucapkan pada-Nya Karena-Nya aku dan kamu bisa menjadi kita

DIA menjadikan kita agar bisa bersatu Maka bersyukurlah kepada-Nya Cukup DIA yang pantas dipuji, jadi jangan puji diriku 


\section{Terima Kasih Sudah Mecintai-Nya}

Kita tak pernah tahu apa yang ada di depan Walaupun kita terlihat lancar menjalani sebuah kehidupan

Jika kita meyakini semua sudah di tuliskan Lantas, apa hak kita untuk terus-menerus mengeluhkan

Dirimu masih sibuk membicarakan

Tentang mencintai atau dicintai Hanya saja mereka mudah melupakan

Siapa yang seharusnya kita dekati

Dirimu berkata "aku butuh teman" "Yang membuatku nyaman setiap waktunya" Dirimu tak merasa keluarga adalah teman Yang selalu ada tanpa mengaharap apa-apa

Ada cinta, karena tanpa cinta tidak akan ada kita

Tapi bagaimana dirimu bisa merasakan Jika dirimu selalu terjatuh dan jauh dari-Nya Maka cinta dari-Nya takkan kamu dapatkan

Allah tak pernah memilih aku atau kamu Karena cinta-Nya tidak hanya mencakup diriku dan dirimu Allah tak pernah meminta balasan cinta-Nya Hanya saja kita harus PEKA dengan segala pemberian-Nya

Terima kasih sudah mencintai-Nya Walau terkadang kasih sayangmu masih saja mendua Kalahkan nafsumu dan jangan lupa untuk selalu mensyukurinya 


\section{Trauma Masa Lalu}

Aku punya cerita di masa lalu

Di mana aku benar-benar terombang-ambing Pengulangan kata untuk menguatkan statementku Agar semua yang aku tuliskan tidak membuat pening

Trauma atas masa laluku sendiri

Membuat aku benci dengan sebagian dari mereka

Trauma yang selalu aku jadikan pertahanan diri Untuk membuatku aman dari mereka yang tak punya etika

Trauma di masa lalu

Memang sering menjatuhkanku

Ketika aku sedang menginginkan ketenangan

Selalu saja buyar seketika dan mulai kehilangan tujuan

Trauma di masa lalu

Memang sering melemahkanku

Ketika aku sedang mencoba berusaha taat

Selalu saja berantakan dan nafsu mulai terikat

Trauma di masa lalu

Memang sering buat risau jiwaku

Ketika aku sedang ingin serius menjalani kehidupan

Selalu saja rencana tak sesuai dengan yang diharapkan

Andai saja trauma itu bisa mudah teratasi

Aku tidak akan mudah jatuh dan jauh dari-Nya

Selalu saja diri meminta untuk menepi

Aku harap, aku selalu didekatkan dengan hidayah-Nya 


\section{Tujuan Hidup}

Jika ditanya "apa tujuan hidupku?"

Tujuanku adalah beribadah kepada-Nya

Jika ditanya "apa motivasiku?

Motivasiku berbuat baik kepada semuanya

Setiap orang memiliki tujuan hidup yang berbeda Ada yang hanya memikirkan harta, tahta atau wanita

Entahlah, semua itu terserah mereka yang memilih Ingatlah, selalu ada resiko ketika mereka mulai memilih

Ibadahku, Hidupku, Dan Matiku, Hanyalah untuk-Mu

Jika mereka masih bingung dengan tujuan mereka Berarti mereka memang tak mengerti tujuan-Nya Aku akan terus berusaha berbagi kepada mereka Agar mereka tahu seberapa besar kuasa-Nya

Tak ada tandingan Itu sudah di jelaskan

Tapi dari mereka masih saja membandingkan Membandingkan antara DIA dengan yang lain

Semoga DIA selalu menemaniku

Dalam menjalankan setiap ibadahku

Dan semoga DIA memberikan rahmat kepadaku, kepadanya, dan kepada mereka semua

Aamiin 


\title{
Tunggu Aku
}

Ku rangkai kata dibenakku

Sambil bersantai ku tuliskan sebuah lagu

Khayalku selalu menari-nari

Membayangkan jika kamu ada di sini

Diri ini belum mampu untuk bersama

Karena diri ini masih lemah menghadapimu

Aku takut membuat dirimu kecewa

Jika aku memaksa hadir untuk menemanimu

\author{
Nanti, pasti, aku datang \\ Tapi, aku harap kamu tak menungguku \\ Jagalah hatimu sampai petang \\ Karena malam, aku akan memimpikanmu
}

\section{Maaf ayah, bukannya aku tak patuh kepadamu Tapi aku ingin bersama dengan yang cinta juga kepadaku \\ Maaf ibu, bukannya aku tak sayang kepadamu Tapi izinkan aku mempersiapkan seseorang yang akan mengisi hidupku}

Buat kamu yang sedang menunggu

Tetap menunggu dengan kesabaranmu Jika bukan aku, pasti dia akan lebih baik dari diriku Jangan kecewa dengan-Nya, karena itu yang terbaik untukmu

Jatuh cinta adalah hal biasa bagi manusia Maka berikanlah cintamu 
Kepada seorang yang juga mencintai-Nya Jangan sampai salah pilihanmu

Karena apa yang kamu jalani Adalah sepertiga rencana dari-Nya Tinggal bagaimana kamu menyikapi Bersyukur selalu adalah kuncinya

\author{
Aku bukan pahlawan \\ Tapi aku bisa menjadi pahlawan \\ Sedang dirimu tak butuh pahlawan \\ Melainkan seorang yang setia di balik mendungnya awan
}

Tunggu aku jika menurutmu aku pantas buatmu Jika DIA berkehendak lain

Cukup terima dan berikan semua do'a terbaikmu

Jangan kalah dengan nafsu Yang selalu mencoba mengalahkan dirimu

Kendalikan terus emosimu Karena hidup itu selalu berjalan maju

Yakinlah pada-Nya selalu Karena-Nya aku bisa bersamamu 


\title{
Tutuplah Auratmu
}

Kamu membuka demi ketenaranmu Kamu membiarkan orang melihat auratmu

Tanpa kamu sadari ini yang terpenting bagimu Kamu melepaskan semua penutup yang ada padamu

\author{
Perintah-Nya sudah jelas aku katakan \\ Dan berkali-kali aku mengingatkan \\ Masalah aurat jangan kamu hiraukan \\ Kalau kamu tak ingin di rendahkan
}

Jika berbicara pandangan

Bukan hanya pria yang menjaga

Karena sebuah kesucian

Keduanya harus saling menjaga

Tutuplah auratmu karena-Nya

Bukan menutup karena sebuah pujian

Menutup aurat itu kewajiban dari-Nya

Maka kerjakan janganlah kamu mengabaikan

Harapanku kamu bisa menjadi lebih baik

Tanpa menilai yang lain dan membuat pelik

Sayangnya kamu selalu menilai kekurangan orang lain

Tanpa berfikir apakah diri, sudah menjadi yang di ingin

Benahi diri demi masa depanmu sendiri

Bukan untukku, tapi untuk kebaikanmu sendiri

Jadi jagalah dirimu selalu, untukmu, dan untuk keluargamu 


\title{
Ucapanku Untukmu
}

\author{
Sahabatku,
}

Aku, bukan orang kaya yang bisa memberikanmu barangbarang mewah

Aku, bukan malaikat yang selalu tahu apa saja keinginanmu

Dan aku, bukanlah orang tuamu yang selalu setia memberikan kasih sayang kepadamu

Aku, hanyalah sahabatmu

Yang hadir dalam kehidupanmu

Dan sudah memiliki posisi di dalam hatimu

Bukan untuk menjadi kekasihmu tetapi sebagai pelengkap warna dihidupmu

Maaf, tak ada kado spesial dariku dihari spesialmu

Aku sengaja tak memberikan kado itu kepadamu

\author{
Karena, \\ Aku tak ingin,
}

Persahabatan kita bergantung pada kado dihari spesialmu Sebab sebagus apa kado yang aku berikan kepadamu Akan selalu ada yang lebih indah dari kepunyaanku Dan persahabatan yang aku tahu, adalah hubungan yang selalu mengikat hingga akhir waktu

Jika kamu menunggu ucapan SELAMAT dariku Takkan ada pernah ada ucapan SELAMAT itu

Karena aku tahu tuntunanku tak pernah mengajarkanku Dan aku tahu bukan itu yang dibutuhkan olehmu 
Do'a adalah sebaik-baiknya sebuah ucapan Semoga kamu bisa menjadi lebih baik diwaktu kemudian Demi dirimu, jodohmu, dan malaikat kecilmu nanti Yang akan selalu kamu pandang setiap hari

Maaf jika tulisanku terlihat membosankan Karena beginilah caraku mengekspresikan

Salam dariku, Sahabatmu 


\title{
Uniknya Dirimu
}

Allah menciptakan kita dengan beragam rupa Kita seharusnya mengerti akan keterbatasan kita Keunikan diri yang bisa membedakan aku dan dirimu Bagaimana bisa paham, jika selalu meninggikan egomu

Aku dan kamu memiliki karakteristik

Yang tak semua orang memiliki itu

Jangan menjadi orang yang selalu mengkritik

Jika kamu sendiri belum bisa memahami dirimu

Aku dan kamu memiliki sifat dan watak yang berbeda Jangan coba memaksa orang lain untuk memahamimu Jika kamu belum bisa mengerti dirimu Bagaimana bisa mereka menghargaimu

Allah memiliki banyak cara untuk berkomunikasi Jangan jadi orang yang selalu menang atas diri sendiri Allah menciptakan kita dengan segudang keistimewaan Jangan jadi orang kufur atas semua yang sudah diberikan

\author{
Uniknya dirimu \\ Membuat orang terpesona \\ Temukan dirimu \\ Jika kamu ingin menjadi manusia
}

Aku yang selalu cacat dalam menyampaikan Hanya bisa bersyukur atas semua yang sudah diberikan Berharap kamu bisa menemukan keunikan dalam dirimu Agar dirimu bisa selalu bersyukur atas semua itu 


\title{
Wanita
}

Sebab dia wanita

Tulang rusuk pria Jangan kau remehkan Bisa saja kau dijatuhkan

\author{
Mereka dititipkan rahim oleh-Nya \\ Dan hanya dia yang memilikinya \\ Sebab itu jagalah dia dengan cara-Nya \\ Jangan sesekali kau merusaknya
}

Masih saja ada yang membuatnya terluka Itulah mereka yang tak pernah mau peka Padahal sudah jelas dari sana asalnya Tapi memang mereka suka menyiksa

Tempat di mana 9 bulan kita berada Dari tak berbentuk sampai menjadi seorang bayi

Tertutup mata mereka untuk melihatnya Karena mereka tak pernah mau memeriksa diri

Wanita bukanlah tempat pelampiasan

Sebab dia selalu memberikan kebaikan Tapi aku selalu kesal dengan godaan mereka Yang menurutku terlalu murah perkataannya

Hei pria yang kesepian

Jangan kau lukai wanita, karena dari sana asal kalian Aku mewakili semua pria memohon kepadamu Aku harap kamu memaafkan kami yang selalu melukaimu 


\title{
Yakin Pada-Nya
}

Ada satu jalan yang Rasul ajarkan Yakni jalan menuju kebenaran Jika kamu selalu mengabaikan Bagaimana bisa kamu dapatkan

Apa yang didapat Jika kita tidak taat DIA selalu memberi pilihan Agar kita tidak mengabaikan

Yakin kepada-Nya Adalah keharusan

Jika kita menghiraukan pesan-Nya Kita akan merasakan sebuah kekecewaan

$$
\begin{gathered}
\text { Yakin kepada-Nya } \\
\text { Adalah sebuah jalan }
\end{gathered}
$$

Jika kita menunda taubat kepada-Nya Kita akan merasakan sebuah penyesalan

\author{
Yakin kepada-Nya \\ Adalah sebuah penghaparan
}

Jika kita terus berharap kepada makhluk-Nya Kita takkan merasakan sebuah kebahagiaan

Aku percaya, kamu pun percaya kepada-Nya Karena yang aku tahu, DIA juga mencintai kita Semoga kita berada dijalan yang diharapkan oleh-Nya 


\section{Zona Nyaman}

Zona Nyaman Adalah sesuatu tempat

Di mana kita merasa tenang di dalamnya Tanpa ada paksaan dan beban yang berat Kita bisa mengekspresikan semuanya

Sebab DIA selalu memberikan nikmat-Nya Adalah teman-teman yang melangkapi keseharianku

Teman-temanku adalah penghibur setiap lara Karena kesedihan yang hadir selalu saja menguburku

Mereka berkata kepadaku "untuk apa kau fikirkan itu?"

Aku pun menjawabnya "aku akan berusaha melupakannya"

Teman-teman adalah jembatan candaku

Yang selalu ada di kala sedih melanda Walau terkadang candanya menyanyat hatiku Tak apa, karena aku tahu bukan itu tujuannya

Zona nyaman membuatku terlena Dengan hiruk pikuk ramainya kota Jika aku salah memilih tempat bergaulku Kelak aku akan kembali ke masa laluku

Begini kurasa cukup

Karena dengan begini beban di pundak sedikit reda Semoga DIA merestui hubungan aku dan mereka 
"About Life" 


\section{"apa yang kamu rasa,}

tak semua bisa kamu ekspresikan. tapi dengan menulis, kamu lebih dari sekedar berekspresi. abadikan kisahmu dengan menulis. jangan biarkan sang cucu lebih mengenal tokoh dunia dibanding dirimu"

\section{"nur fitria ayu fahdila"}


"Ibarat Mentapi yang telah lama menyediakan warna-warninya.

Tetapi, Uap setelah $h u j a n_{\text {yang }}$ tampilkan pelanginya.

Kadang musibahlah. yang menikmatkan Miknat."

Ustadz Salim A. Fillah 


\section{Musibah adalah Berkah}

Musibah pasti datang ke semua orang, mungkin kita tidak tahu sekarang apa yang tampak di depan. Namun, masa lalu orang siapa yang paham. Bisa jadi dahulu, musibah sekali datang, tergantung bagaimana kita memberi tanggapan. Apakah kita dapat mengambil pelajaran atau justru angkat tangan tanpa perjuangan?.

Musibah menjadikan nikmat semakin terasa. Kehilangan yang membuat kita tahu bahwa ternyata hal itu berharga. Itulah hukum alam semesta. Selalu ada segala yang selalu berlawanan makna. Tanpa ada hujan, pelangi tak akan menampakkan dirinya pada bumi. Tanpa ada duka, hal yang bahagia terasa biasa saja. Tanpa ada musibah, mungkin kita akan lupa mensyukuri segala nikmat dan anugerah-Nya.

Terkadang kita harus bersyukur terhadap segala musibah dan ujian. Karena turunnya, merupakan bagian dari rencana Allah SWT. Karena datangnya membawa hikmah, baik hikmah yang datangnya dengan tamparan maupun dengan kelembutan. Baik hikmah yang datangnya dijemput diri sendiri maupun perantara lingkungan. Sebab dengan hikmah, Allah SWT turunkan kebaikan yang melimpah. 
"Sangat cepat membusuk dan layu. apabila kulit pisang di tinggalkan isiny.

Bagaimanakah hati, bila imannya pergi?"

Ustadz Salim A. Fillah 


\section{Iman dan Hati}

Iman merupakan sebab untuk meraih kebahagiaan dunia dan akhirat. Dengan iman itulah, seseorang akan bisa merasakan ketenangan dan ketentraman, ketenangan hati dan ketentraman jiwa. Demikian pula, kelezatan dunia dan akhirat akan tergapai dengannya.

Terkadang kita lupa, ketika sedang surut-surutnya iman, kita malah meningkatkan maksiat kita. Allah SWT memberikan hidayah kepada mereka yang berusaha mencari hidayah-Nya. Jika kita selalu menutup diri untuk menerima hidayah dari-Nya, lantas dengan apa kita bisa bersama Allah SWT disyurga-Nya.

Keputus asaan yang membuat kita ragu untuk menguatkan iman. Dengan jalan terpaksa kita melakukan perintah-Nya. Jika Allah SWT mencabut semua nikmat yang ada pada diri kita, lantas seperti apa kehidupan kita?

Iman dan Hati adalah komponen utama dalam kehidupan, dengan Hati kita bersyukur dan dengan Iman kita berusaha untuk selalu bersama-Nya. 


\section{Kuatkan niat, niatkan}

"Lillah" karena Allah swt,

\section{Insya Allah, DIA akan} memudahkan dan menguatkan untuk menjalankan sunnah-Nya. Tetap tegar, sabar, dan istiqomah untuk selalu memperbaiki diri"

"Allah tidak membebani seseorang melainkan sesuai dengan kesanggupannya"

[2:286] 


\section{Cadarku terhalang restu orang tua}

Jangan berharap masuk syurga jika dirimu belum diuji, etika kita ingin berubah menjadi pribadi yang lebih baik dan meningkatkan level taqwa serta kebajikan pasti ada ujiannya, akan banyak tantangannya baik itu dari keluarga, teman ataupun masyarakat sekitar. Namun jangan jadikan hal tersebut menjadi penghambat untuk terus memperbaiki diri.

Seperti hal yang sering kita jumpai, ketika ingin memakai cadar atau memutuskan untuk memakai cadar namun terhalang restu orang tua. Banyak yang bertanya. Gimana sih menghadapi orang tua yang tidak mengizinkan anaknya untuk bercadar?

Untuk menghadapi orang tua kita perlu waktu dan kesabaran, jelaskan pada orang tua bahwasanya kita bercadar tujuannya baik, untuk mejaga diri dan kehormatan keluarga serta kelak agar orang tua tidak menanggung dosa akibat perbuatan kita di dunia. Jika kita bisa menghadapi orang tua kita dengan sabar dan lemah lembut, maka Insya Allah dengan berjalannya waktu pasti kita akan mendapatkan ijinkan dari mereka. 


\section{Sahabat sejatimu adala sahabat yang}

senantiasa jujur , bukan senantiasa membenarkanmu. 


\section{Persahabatan Until Jannah}

Bersahabat dengan orang-orang yang shalih, Adalah nikmat yang sangat besar. Dan apabila kita diberikan sahabat yang shalih, maka pegangkah erat-erat jangan sampai terlepas.

Mereka akan selalu membenarkan dan menasehati apabila kita salah, bukan hanya sahabat yang hanya senang-senang saja atau hanya sahabat yang memuji karena basa-basi saja. Mereka akan selalu mendoakan sahabatnya, karena keshalihannya dengan izin Allah SWT maka kita akan mudah menjadi orang yang shalih.

Apakah kenikmatan terbesar dari pesahabatan yang shalih? Kenikmatannya adalah kebahagiaan kita akan berlanjut sampai surga dan kekal selamanya.

Persahabatan yang shalih didunia akan dipisahkan dengan kematian, dan akan berlanjut dan dikumpulkan bersama di akhirat kelak.

Setiap orang akan dikumpulkan bersama orang yang di cintai, Sahabat akan menolong kita agar kita bisa bersama-sama masuk surga dan berkumpul kembali 
Do'akan selalu mereka yang sampai saat ini membicarakanmu dan membencinu.

Buanglah $h_{\text {semua dendam }}$ yang sampai saat ini merusak hatimu.

Karena hakikatnya SEMUa komentar mereka hanya sebatas lidah dan takkan kita

bawa sampai ke alam barzah. 


\section{Hiraukan Sesuatu Yang Tak Perlu}

Jangan hiraukan seburuk apapun penilaian orang terhadapmu, karena sesungguhnya hidup bukan untuk mendapatkan pujiannya namun mengharapkan Ridho-Nya.

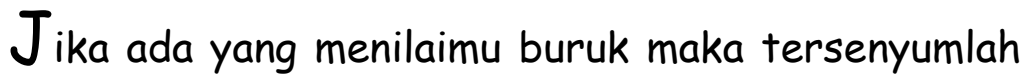
dan lupakan perkataannya. Jika ada yang memandangmu hina maka biarkanlah karena sesungguhnya kamu indah dimata Sang Pencipta.

Hidup kita bukan tentang mereka atau bagaimana mendapatkan berjuta pujian dari mereka, tetapi hidup kita tentang bagaimana Allah ridho atas apa yang kita lakukan.

Biarkan orang berkata buruk karena mereka hanya melihat tanpa mengetahui tentangmu. Biarkan saja orang memandangmu rendah karena sesungguhnya mereka iri dengan apa yang kamu miliki.

Ingatlah bahwa semakin besar pohon, maka semakin kuat angin yang akan menerpanya. Belajarlah dari sebuah pohon, sekuat apapun angin menerpanya dia tak pernah membencinya. Seperti itulah kita, seburuk apapun penilaian orang terhadap kita maka semakin sayanglah kita padanya. 


\section{Allah SWT selalu}

bersama kita dan selalu menyayangi

kita. moka kuatkan

hati dan bersshanala $a g a r$

selalu dekat

dengan-Nya 


\section{Ketenangan Hati}

Isi hati siapa yang tahu tentang ini?, Kecuali Allah SWT dan diri kita sendiri. Tetapi berbeda jika kita menceritakan isi hati kita kepada orang lain. Sejujur-jujurnya, menceritakan rasa, apakah kita sedang gundah gulana, sakit, ragu, lelah, senang gembira, bahkan hati kita yang sedang jatuh cinta itu tidak mudah. Pasti kita punya kepercayaan yang bisa menjadi tempat curahan hati. Seseorang yang kita percaya, yang menjadi pendengar setia dan baik buat kita.

Kertas dan pena, mungkin itulah yang setiap hari menjadi torehan rasaku. Tapi yang ku rasakan sekarang ini tentang ketenangan hati. Ketika hati tak tenang, hanya Allah SWT yang menjadi sandaran terbaik.

Allah SWT memberikan solusi dengan isyarat atau kejadian yang ada di depan kita. Mungkin sekarang kita masih berfikir untuk apa Allah SWT memberikannya. Padahal yang kita butuhkan saat ini bukan itu. 
Lidahku yang suka berbohong. Lidanku yang

suka mengumpat dan bergosip ria. Lidahku yang suka memfitnah dan menuduh, dan Lidahku yang suka berucap kotor. 


\section{Lidah Yang Tak Bertulang}

Ketika lidah tak terbendung berucap, Berakibat dosa seluas bentangan langit.

Segala amalanku di dunia ini akan di bentangkan di akhirat, walaupun sekecil biji zara. Pada waktu itu aku akan bisa melihat apapun yang aku lakukan di dunia. Aku yang berdosa ini akan merasa takut dengan keadaan waktu di hari perhitungan. Dengan lidah kita di benarkan dan dengan lidah pula kita banyak melakukan dosa.

Kuat beribadah dan memiliki pahala yang banyak tidak menjamin terpeliharanya seseorang itu dari azab Allah SWT jika pada masa yang sama masih melakukan kedzaliman kepada insan lain.

Jika kita miskin di dunia masih ada orang yang bersimpati dan dapat membantu, tetapi siapakah yang menyelamatkan kita dari azab siksaan-Nya?

Kita memerlukan kekayaan untuk mendapatkan Amal Kubur yang luas dan terang, berada di Padang Mahsyar dengan meniti Titian Siratul Mustaqim sepantas kilat, melintasi pintu syurga serta membina mahligai besar salam syurga. 
"Bukankah Manusia selalu khilaf dalam melakukan segala hal. Karena hijab adalah SUatu kewajiban. selamat berjuang memperbaiki diri, mari kita atur akhlak dan perilaku kita menjadi baik sebagaimana sudah di atur dalam Al-Qur'an dan Hadist untuk $_{\text {selalu }}$ dekat dengan Allah SWT. 


\section{Aku Tak Lebih Baik dari Kalian}

Jangan lihat postinganku, karena yang kalian temukan hanya sepenggal kata dakwah di dalamnya. Postingan dakwah bukan berarti aku pandai dalam urusan agama. Aku hanya mencoba membagikan ilmu yang baru saja aku dapatkan.

Baiknya pakaianku, tidak sebaik akhlakku. Karena sungguh dalam hal ini, aku pun perlu proses untuk memperbaikinya.

Maka jangan pernah menganggap aku lebih baik dari kalian hanya karena melihat postingan dan hijab yang aku kenakan.

Namun sebelumya, jangan pernah berfikir dengan berkata 'percuma posting agama, nasihatin orang lain, tapi dirinya sendiri belum benar'. Tidak sahabatku, jika berbagi ilmu menunggu diri menjadi benar, maka sampai kapan?

Karena aku juga manusia dan sudah kodratnya bahwa manusia tidak luput dari dosa. Dan jangan sekali lagi pernah berfikir dengan berkata 'percuma berhijab, kalau hatinya belum baik. Kerudung aja dipanjangin tapi akhlaknya beda jauh dari kerudungnya. 
Kehidupan dunia bagai bunga yang dipe tik kemudian layu. Dunia itu penjara ${ }_{\text {bagi }}$ orang mukmin dan surga $a_{\text {bagi }}$ orang yang kafir. 


\section{Dunia}

Ibaratkan dunia seperti bunga, Ketika tanaman yang hendak berbuah, Selalu berawal dari muculnya bunga, dan terkadang bunga itu akan selalu terlihat indah

Disisi lain terkadang begitu menawan, Orang yang melihat pun terkadang ingin memetiknya, dan merekapun membawanya pergi.

Lalu bagaimana dengan bunga yang dipetik tadi?, dia akan layu dan pada akhirnya akan dicampakan. Memang jika dia masih berada di tangkai dia begitu mempesona, namun jika sudah dipetik pasti akan layu.

Berbeda jika kita biarkan dia hidup bersama tangkainya, Dia akan berubah menjadi buah, tidak hanya indah dipandang dan dinikmati, namun dia menyejukkan pandangan dan bermanfaat.

Seperti halnya dunia ini, gambaran dunia dapat dipastikan kisahnya sama seperti bunga. Kehidupan dunia itu terlihat begitu indah, begitu menawan dimata siapa saja yang melihat dan memandangnya.

Tahta, jabatan, wanita, keturunan, harta, benda dan lainnya, semuanya nampak menggoda dan 
membuai nafsu kita. Sama halnya manusia yang jiwanya tergoda, yang jiwanya berhasrat ingin menggapai dan menikmatinya.

Akan tetapi, segala yang terlihat indah dimata sejatinya akan jauh lebih indah, jika ditunggu sebentar saja, yakni kehidupan akhirat.

Hanya mereka yang terlena dan tergoda, sehingga mereka tak dapat menahan kecuali memetik dan menikmatinya.

Sesungguhnya cepat atau lambat apa yang dipetik akan layu, nampak suram dan bisa menjadi bencana yang sangat mencekam.

Begitulah Allah menguji hamba-hamba-Nya, dan di mana mereka tergesa-gesa menikmati keindahan sebelum waktunya.

Mengapa dunia ini dipenuhi dengan aturan-aturan?, Yang tidak boleh sama sekali di langgar dan diterjang. Ada halal dan haram, ada ini dan ada itu. Kerap sekali ketika kita menjalankan suatu perintah, kita harus meninggalkan beberapa perkara yang nampak begitu indah.

Ada saatnya pula kita harus menelan rasa pahit, Ketika kita sudah merasakan keindahan dunia, Kelak 
di negeri kekal kita tak akan lagi merasakan indahnya syurga, Karena hanya nerakalah tempat yang teduh untuk kita.

Dunia memang laksana fatamorgana, Sepertinya megah namun hakekatnya lemah. Hina dan dekat, Hina karena harganya yang tak ada apa-apanya dibandingkan akhirat, Dekat karena kedekatannya dengan kampung akhirat.

Demikianlah seorang muslim seharusnya benarbenar menyadari, betapa dunia hanyalah negeri yang penuh dengan fatamorgana. Dunia bukanlah tempat bersenang-senang, Dunia merupakan kampung untuk mencari bekal, dan akhiratlah tempat memetik buah amal.

Sesungguhnya Allah memiliki beberapa hamba yang cedik, Mereka menceraikan dunia karena khawatir akan bencana, Mereka merenungkan isi dunia, Ketika mereka mengetahui bahwa dunia bukanlah kehidupan yang sebenarnya.

Tanah, air, orang yang hidup, Merekapun
menjadikannya laksana samudera, Dan mejadikan
amal shalih sebagai bahteranya 
"Semoga $\mathbf{U h}$ WWah $\mathbf{h}_{\text {yang dimulai }}$ dengan prasangka suci. bisa terwujud bersama-sama. Ya Allah, tunjukilah kami jalan-Mu,

terangilah ukhuwah kami, semoga ketulusan KaMi selalu berada di dalam nungan ridhoMu. 


\section{Ukhuwah Islamiyah}

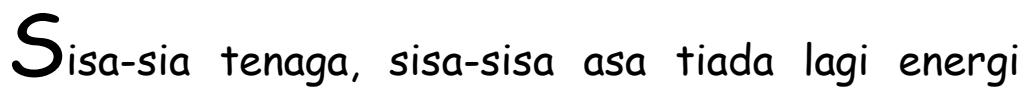
untuk berbagi isi rasa, cukup lelah untuk berkeluh kesah.

Raga ini cukup lelah, pikiran ini cukup penat, mata ini sudah tidak mampu lagi menahan rintihan kesedihan, hanya jemari ini yang mampu menuliskan serangkaian kata berusaha mengurangi rasa sesak di dada.

Ya Allah, inikah puncak kesanggupan hamba-Mu ini, semoga ENGKAU senantiasa memberikan penguatan pada hamba.

Sekian lama memendam dan meredam semua rasa jenuh, bosan dan kecewa. Sudah sekian lama berusaha mengajak hati untuk berdamai dengan keadaan.

Sudah sekian lama menghaluskan perasaan, mengindahkan prasangka. Keistimewaannya membuat pemilik hati harus berhati-hati dengan hati. Manusia dianugerahi oleh Allah SWT segumpal daging yang sangat sensitif, ya itulah hati. 
Jika hati terluka maka akan perlu waktu cukup lama untuk menyembuhkannya. Waktu yang mampu mengobati rasa sakit hati, menunggu luka itu mengering, dan tak terasa sakit lagi, serta menunggu sampai luka itu hilang walau harus meninggalkan bebas yang tak terlihat.

Ukhuwah, sebuah kata yang sangat indah. Ukhuwah antar sesama muslim, saudara-saudariku seiman, dan saudara-saudariku seamanah.

khuwah ini sangat indah, tak dapat di uraikan dengan kata-kata. Karena ukhuwah bukan ucapan formalitas saat bertemu, ukhuwah bukan ungkapan simpatik saat saudara dalam musibah, ukhuwah bukan senyum hampa.

Ikatan ini adalah ikatan hati, ikatan yang akan menjaga saudara-saudariku dalam lingkaran kebaikan. Ikatan yang akan menuntun saudarasaudariku bersama-sama sampai pada tujuan akhir yaitu bersua di Jannah-Nya.

Bukan tidak mungkin, suatu perniagaan dengan Sang Pencipta akan mudah dalam perjalanannya. Pastilah jalanan terjal berbatu, dan berbagai cobaan 
pasti akan mewarnai perjuangan demi mendapatkan posisi terbaik di sisi-Nya.

Begitu pula dengan ukhuwah, ada masa yang terasa manis dan ada pula yang terasa pahit. Ketika kita merasa tersakiti dalam suatu ikatan ukhuwah, coba ingat kembali segala keindahan persaudaraan itu. Ketika kita sampai dititik jenuh permasalahan ini, coba pahami lagi janji-janji-Nya yang telah disiapkan bagi orang-orang yang bersatu untuk membela kebenaran.

\section{P}

ertemuan dan perpisahan adalah ketentuan Ilahi, suatu momen yang mungkin akan semakin menyisakan goresan luka, perpisahan yang belum pada waktunya, dikala masih saling memerlukan bantuan, disaat masih membutuhkan dorongan penguatan.

Jangan sampai, kita meninggalkan amanah, meninggalkan generasi penerus, meninggalkan teman perjuangan dalam keadaan lemah. Sungguh, hal itu tidak disukai oleh Allah SWT. 


\section{Sakit badan tidak}

\section{merasakan lezatnya makanan,}

penyakit hati juga demikian.

Hati yang sakit $t$ idak akan bisa

dapat $_{\text {merasakan }}$ manisnya

\section{iman.}




\section{Hati Yang Sakit}

Ketika badan sakit, makanan selezat apapun pasti terasa tak enak. Demikian juga dengan hati, apabila hati yang sakit, kita tidak akan merasakan manisnya iman. Yaitu kebahagiaan dan ketenangan sejati di dunia dan akhirat.

Jika di dunia sebagian orang mengatakan, sungguh rugi, sudah datang ke kota ini dan tidak merasakan makanan khasnya. Demikian juga dengan manusia yang hidup di dunia, sangat merugi apabila tidak merasakan yang namanya manisnya iman.

Iman itu memiliki rasa manis dan manusia bisa merasakannya. Manisnya iman itulah surga dunia, "Barang siapa di dunia tidak pernah merasakan manisnya iman, maka di akhirat tidak mendapatkan kebahagiaan berupa syurga di akhirat".

\section{Bagaimana seseorang mendapatkan manisnya iman?}


Dia yang mecintai Allah dan Rasul-Nya melebihi segalanya. Apabila ia mencintai seseorang, ia hanya mencintainya karena Allah. Ia benci untuk kembali kepada kekufuran setelah Allah menyelamatkannya, sebagaimana ia benci untuk dilemparkan ke dalam neraka.

Sesungguhnya di dunia ada surga, siapa yang tidak memasukinya, maka ia tidak akan masuk surga di akhirat.

Bagaimana dengan janji Allah kepada mereka yang beramal shalih?, Dia akan diberikan kehidupan yang baik dengan manisnya iman. 
Selesai sudah

tulisanku dan tulisan dari sahabat penaku.

semoga semua yang sudah aku dan sahabatku tuliskan bisa menjadi motivasi. semangat baru dalam kehidupanmu $d$ an juga semoga Allah SWT selalu menyertaimu. 


\section{Tentang Penulis A Poem}

Namanya adalah Muhlis Muhammad Abdullah, lahir di

Paniai pedalaman pegunungan mulia, 3 Maret 1996. Dia adalah anak pertama dari tiga bersaudara. Adik pertamanya bekerja sebagai montir, dan adik keduanya sedang melanjutkan studi tepatnya di Sekolah Tinggi Agama Islam Negeri Sorong. Kedua orang tuanya berprofesi sebagai ibu rumah tangga dan pegawai negerin sipil semenjak dirinya masih kecil. Sedangkan dirinya, saat ini sedang melanjutkan studinya dikampus yang sama dengan adik keduanya.

Semasa kecil lingkungan keluarga menjadi peran utama, namun semenjak remaja hingga saat ini, kehidupan malam sangat bersahabat dengannya. Bukan karena dirinya tak betah berada dirumah, hanya saja kehidupan malam sedikit membuatnya lebih baik walaupun perubahan tidak terlalu signifikan, tapi dia percaya semua perubahan itu butuh proses dan kita harus menikmatinya.

Dia juga mempunyai skill yang cukup langka untuk saat ini, dia seorang teknisi parttime. Sejak lama kedua orang tuanya tak pernah berhenti mendidiknya. Walau sedikit keras kepala dengan keduanya, dia tetap berusaha untuk tidak menyakiti perasaan kedua orang tuanya. 
Sebelumnya dia pernah membuat buku sayangnya ditarik kembali karena belum memenuhi syarat. Dan di dalam buku ini semua cerita lengkap, mulai dari kisah cinta, kisah halu, dan motivasi kehidupan tercecer lengkap di dalam lembarang-lembarannya.

Baper buat dia adalah hal utama untuk mengatur ritme penulisan, dengan harapan yang besar juga dia akan terus mencoba berkarya didunia sastra walau sebenarnya ini bukan bidangnya, katanya sih sekedar iseng.

B uatmu yang kepo nih aku kasih kontaknya:
Instagram : @gw_calonmayat
Whatsapp : 082199753860
Line
: @utiz_abdullah
Facebook : Muhlis Muhammad Abdullah
Email
: muhlisabdull96@gmail.com

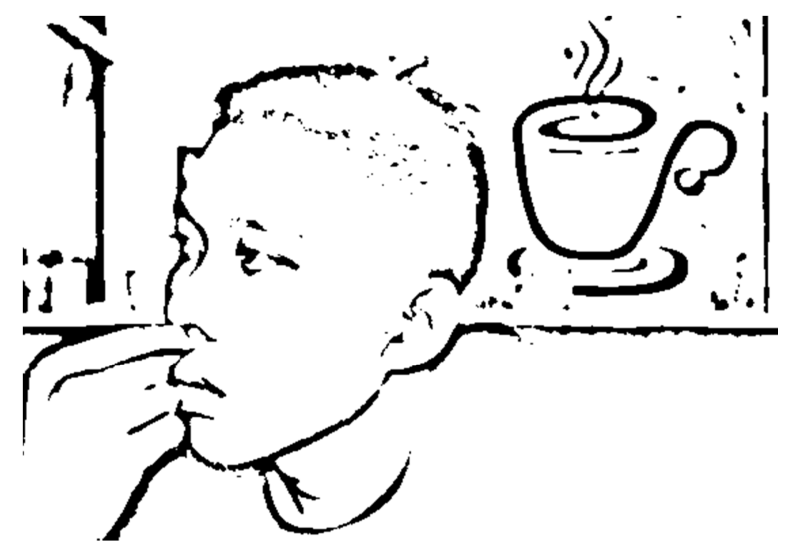




\section{Tentang Penulis About Lífe}

Loh, kenapa ada bagian ini? bukannya ini buku pribadinya ya?, emang iya ini buku pribadinya, tapi dia gak bisa kelarin ini sendiri tau.

Sudahlah nikmatin aja, mumpung ada, kita kelarin siapa sih sahabat pena si ibo dalam buku ini.

Oia bernama Nur Fitria Ayu Fahdila, lahir di kota gaplek, Wonogiri 13 Juni 1999. Dia itu wanita strong loh, jauh dari keluarga mengais rezeki di kota orang parepare tepatnya. Dia dua bersaudara, dan dia adalah anak pertama. Walau keluarga berada di wonogiri dan dia di Parepare, tak membuatnya patah semangat dalam bekerja.

Bekerja dibidang percetakan dan penerbitan yaitu PT.

Intan Pariwara, sebagai Branch Administration di salah satu cabang di Indonesia. Istilahnya orang sibuk lah pokoknya, Si ibo mah kalah sibuknya dengan dia.

Kesehariannya, memenuhi kewajibannya bekerja karena diberi kepercayaan untuk mengurus distribusi perbukuan dan keuangan. Menulis hanya sebagai pelampiasan dikala bosan, karena hasil karyanya bagus, si ibo tertarik tuh buat jadiin sahabat penanya, btw dia juga mau launching 
buku juga sih katanya, kita doakan aja semoga launchingnya sukses selalu, aamiin.

Sama seperti ibo, Dia hanya sekedar mengungkapkan apa yang dirasakan hatinya lewat torehan kata-kata sendu yang disusun menjadi paragraph singkat dan beralur.

Baginya hanya pena dan kertas setelah Allah SWT untuk mencurahkan segala keluh kesahnya menghadapi kehidupan dunia. Walaupun bertolak belakang dengan latar belakangnya hobinya yang satu ini sangat membuatnya puas setiap kali melihat hasil tulisannya.

$Y_{\text {ang mau kepo silahkeun: }}$

Instagram : @ftriafz

Email : nurfitriaayufahdila50@gmail.com

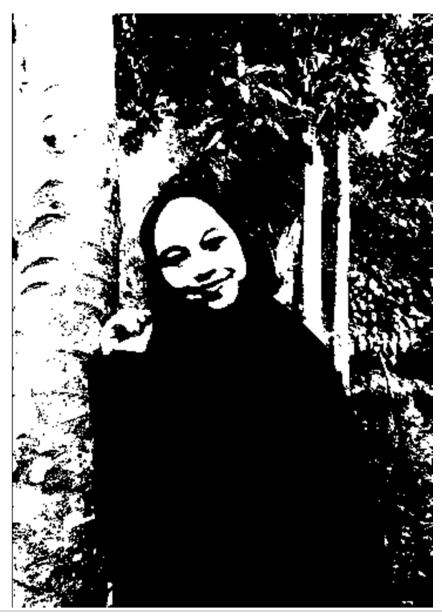




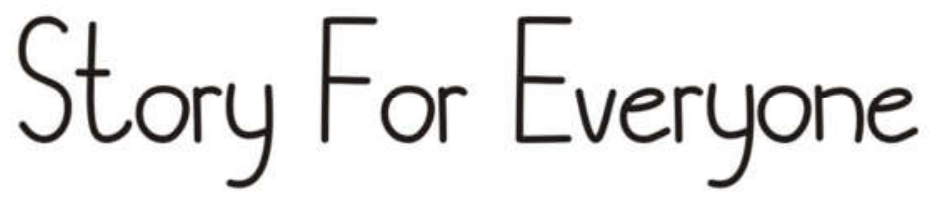

SEPATAH DUA PATAH KATA YANG TERSUSUN SAMPAI SINI AKU MENGATAKAN SAMPUN SEMUA TULISAN AKAN ADA POIN INTI SETIAP KEHIDUPAN PASTI AKAN PERGI

TIDAK ADA MANUSIA YANG BENAR HANYA ALLAH YANG MAHA BENAR TIDAK ADA MANUSIA YANG BIJAK HANYA ALLAH YANG MAHA BIJAK

\section{TAATI, JALANI, NIKMATI}

